UNIVERSIDADE DE SÃO PAULO - USP

ESCOLA DE ARTES, CIÊNCIAS E HUMANIDADES - EACH

PROGRAMA DE MESTRADO EM TÊXTIL E MODA

Edmundo da Silva Pedro

O processo ensino-aprendizagem em curso superior tecnológico de moda como fator de mobilidade social

São Paulo 
O processo ensino-aprendizagem em curso superior tecnológico de moda como fator de mobilidade social

Dissertação apresentada à Escola de Artes, Ciências e Humanidades da Universidade de São Paulo, para obtenção do título de Mestre em Ciências, pelo Programa de Mestrado em Têxtil e Moda.

Versão corrigida contendo as alterações solicitadas pela comissão julgadora em 17 de março de 2017. A versão original encontra-se em acervo reservado na Biblioteca da $\mathrm{EACH} / \mathrm{USP}$ e na Biblioteca Digital de Teses e Dissertações da USP (BDTD), de acordo com a Resolução CoPGr 6018, de 13 de outubro de 2011.

Área de Concentração: Projeto Têxtil e Moda

Orientador: Prof. Dr. Antonio Takao Kanamaru

São Paulo 
Autorizo a reprodução e divulgação total ou parcial deste trabalho, por qualquer meio convencional ou eletrônico, para fins de estudo e pesquisa, desde que citada a fonte.

CATALOGAÇÃO-NA-PUBLICAÇÃO

(Universidade de Săo Paulo. Escola de Artes, Ciências e Humanidades. Biblioteca)

Pedro, Edmundo da Silva

O processo ensino-aprendizagem em curso superior tecnológico de moda como fator de mobilidade social/ Edmundo da Silva Pedro; orientador, Antonio Takao Kanamaru. - Sáo Paulo, 2017 $112 \mathrm{f}$.

Dissertação (Mestrado em Ciências) - Programa de PósGraduaçấo em Téxtil e Moda, Escola de Artes, Ciencias e Humanidades, Universidade de Sáo Paulo

Versăo corrigida

1. Moda - Estudo e Ensino. 2. Mobilidade social. 3. SENAI I. Kanamaru, Antonio Takao, orient. II. Titulo.

CDD 22.ed. - 391.007 
PEDRO, Edmundo da Silva. O processo ensino-aprendizagem em curso superior tecnológico de moda como fator de mobilidade social.

Dissertação apresentada à Escola de Artes, Ciências e Humanidades da Universidade de São Paulo, para obtenção do título de Mestre em Ciências. Programa de Mestrado em Têxtil e Moda.

Área de concentração: Projeto Têxtil e Moda

Orientador: Prof. Dr. Antonio Takao Kanamaru

Aprovada em: 17/03/2017

BANCA EXAMINADORA

Prof. Dr. Antonio Takao Kanamaru

Universidade de São Paulo. Escola de Artes, Ciências e Humanidades

Prof. Dra. Maria Cecília Loschiavo dos Santos

Universidade de São Paulo. Faculdade de Arquitetura e Urbanismo

Prof. Dra. Maria Eliza Mattosinho Bernardes

Universidade de São Paulo. Escola de Artes, Ciências e Humanidades 


\section{AGRADECIMENTOS}

Agradeço a Deus, primeiramente, pelo dom da vida e por me dar a sabedoria para a concretização deste trabalho.

Ao meu orientador, Prof. Dr. Antonio Takao Kanamaru, pela orientação, apoio, amizade, incentivo e, sobretudo, paciência durante o processo de desenvolvimento deste trabalho.

Às professoras Dra. Maria Cecilia Loschiavo dos Santos e Dra. Maria Eliza Mattosinho Bernardes, integrantes das bancas de Qualificação e de Defesa desta dissertação, pela leitura atenta e pelas contribuições inestimáveis ao trabalho.

À Universidade de São Paulo, por ter me acolhido em seu Programa de Mestrado em Têxtil e Moda e me proporcionado todas as condições para a realização deste trabalho.

À minha família: Lilian Brito de Souza Pedro (esposa), Aline de Souza Pedro e Vinícius Pedro (filhos), que além do apoio, compreenderam a minha ausência durante este período.

Às pessoas que me estimularam no ingresso, na permanência e conclusão do mestrado, às quais serei eternamente grato: Professor Aguinaldo Silva Garcez, Professora Dilara Rúbia Pereira, Professora Dra. Isabel Silva Sampaio e Professora Joveli Ribeiro Rodrigues.

Agradeço especialmente aos participantes da minha pesquisa, ex-alunos do SENAI, sem os quais este trabalho não poderia existir, e a todos aqueles que, direta ou indiretamente, contribuíram para a realização deste trabalho, 


\section{RESUMO}

PEDRO, Edmundo da Silva. O processo ensino-aprendizagem em curso superior tecnológico de moda como fator de mobilidade social. 2017. 112f. Dissertação (Mestrado em Ciências) - Escola de Artes, Ciências e Humanidades, Universidade de São Paulo, São Paulo, 2017. Versão corrigida.

A partir de 2000, a educação profissional vem ganhando cada vez mais notoriedade e atenção no contexto da educação brasileira. Os cursos técnicos passaram por um processo de renovação e melhor definição de seu papel e identidade - tanto no âmbito da organização burocrática quanto da prática pedagógica - e, no âmbito da Educação Superior, a vertente da tecnologia acrescentou diversidade e especialização ao panorama do ensino universitário brasileiro. Nesse contexto, o objetivo deste trabalho é contribuir para a análise sobre a educação tecnológica com ênfase na área de moda e vestuário. Para tanto, foi realizada uma pesquisa com egressos do Curso Superior de Tecnologia em Produção de Vestuário do SENAI-SP, no período de 20011 a 2015, a partir da perspectiva de mobilidade social trazida pelo curso para seus estudantes. A hipótese aqui considerada é a de que o curso, formatado de acordo com 0 modelo de Educação Profissional por Competências adotado pelo SENAI, oferece a seus egressos uma possibilidade maior de mobilidade social, uma vez que o modelo pedagógico adotado, por um lado, propõe a construção do conhecimento e o desenvolvimento de habilidades e competências de maneira autônoma por parte do educando, e por outro, oferece uma formação desenhada a partir das reais demandas profissionais do mercado.

Palavras-chave: Educação. Formação profissional. Moda. Têxtil e Vestuário. Mobilidade social. Competências. 


\begin{abstract}
PEDRO, Edmundo da Silva. The teaching-learning process in fashion technological superior course as a factor of social mobility. 2017. 112f. Dissertation (Master in Sciences) - School of Arts, Sciences and Humanities, University of São Paulo, São Paulo, 2017. Revised version.

Since 2000, professional education has been gaining more and more attention and attention in the context of Brazilian education. The technical courses underwent a process of renewal and a better definition of their role and identity both in the bureaucratic organization and in the pedagogical practice - and in the Higher Education area, the technology aspect added diversity and specialization to the panorama of Brazilian college education. In this context, the objective of this work is to contribute to the analysis on technological education with emphasis in the area of fashion and clothing. For that, a survey was carried out with graduates of the Superior Course of Technology in Clothing Production of SENAISP, from the period of 20011 to 2015 , from the perspective of social mobility brought by the course for its students. The hypothesis considered here is that the course, formatted according to the model of Education by Competencies adopted by SENAI, offers its graduates a greater possibility of social mobility, since the pedagogical model adopted, on the one hand, proposes the construction of knowledge and the development of skills and competences in an autonomous way by the student, and on the other, offers a training designed from the real professional demands of the market.
\end{abstract}

Keywords: Education. Training. Fashion. Textile and clothing. Social change. Skills. 


\section{LISTA DE FIGURAS}

Figura 1 - A Cadeia de Valor Têxtil e Vestuário........................................... 14

Figura 2 - Criação e desenvolvimento do produto ................................... 59

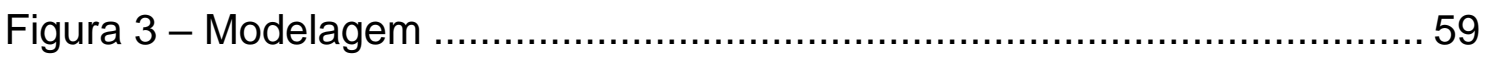

Figura 4 - Estudo de encaixe pelo sistema CAD ...................................6 60

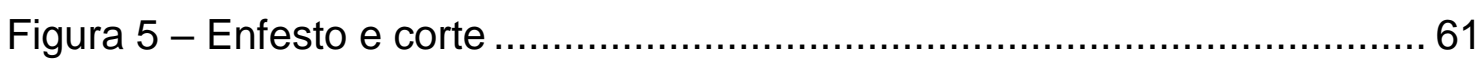

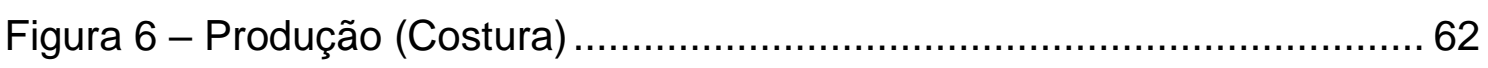

Figura 7 - Controle da produção: cronoanálise ...................................... 62

\section{LISTA DE TABELAS}

Tabela 1 - Evolução do número de IES no Brasil - 2010-2013 ..................... 43

Tabela 2 - Evolução do número de cursos de graduação - 2010-2013 ......... 44

Tabela 3 - Distribuição dos egressos ocupados, por tipo de experiência, no

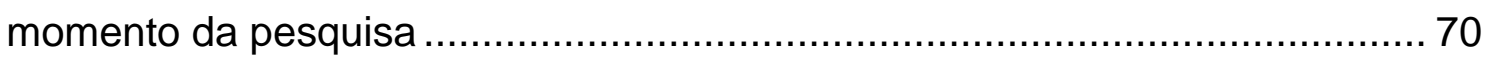

Tabela 4 - Resposta relativas à Etapa 1 da pesquisa ................................ 75

Tabela 5 - Respostas relativas à Etapa 2 da pesquisa............................. 76 


\section{LISTA DE SIGLAS}

CAI - Curso de Aprendizagem Industrial

CST - Curso Superior de Tecnologia

CT - Curso Técnico

DEED - Departamento de Estatísticas Educacionais

INEP - Instituto de Estudos e Pesquisas Educacionais Anísio Teixeira

LDB - Lei de Diretrizes e Bases da Educação Nacional

MEC - Ministério da Educação

PROEP - Programa de Expansão da Educação Profissional

SAPES - Sistema de Acompanhamento de Egressos do SENAI

SENAC - Serviço Nacional de Aprendizagem Industrial

SENAI - Serviço Nacional de Aprendizagem Industrial

SESC - Serviço Social do Comércio

SESI - Serviço Social da Indústria

UNESCO - Organização das Nações Unidas para a Educação, Ciência e Cultura ONU - Organização das Nações Unidas 


\section{LISTA DE GRÁFICOS}

Gráfico 1 - Situação profissional antes do curso - Etapa 1 .............................69 69

Gráfico 2 - Situação profissional antes do curso - Etapa 2 ............................. 69

Gráfico 3 - Situação profissional após o curso - Etapa 1 ............................... 70

Gráfico 4 - Situação profissional após o curso - Etapa 2 ................................ 71

Gráfico 5 - Nível de renda pessoal antes do curso - Etapa 1 ......................... 72

Gráfico 6 - Nível de renda pessoal após o curso - Etapa 1 ........................... 73

Gráfico 7 - Nível de renda pessoal antes do curso - Etapa 2 …..................... 73

Gráfico 8 - Nível de renda pessoal após o curso - Etapa 2 …….................... 74

Gráfico 9 - Nível de escolaridade do pai - Etapa 1 ....................................... 78

Gráfico 10 - Nível de escolaridade da mãe - Etapa 1 .................................. 78

Gráfico 11 - Nível de escolaridade do pai - Etapa 2 ...................................... 79

Gráfico 12 - Nível de escolaridade da mãe - Etapa 2 ................................... 79

Gráfico 13 - Profissão do pai - Etapas 1 e 2 ............................................... 80

Gráfico 14 - Profissão da mãe - Etapas 1 e 2 ................................................. 81

Gráfico 15 - Níveis de remuneração por escolaridade ................................... 82 


\section{SUMÁRIO}

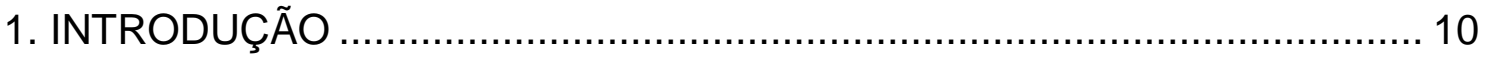

1.1 O setor têxtil e vestuário no Brasil........................................................ 12

1.2 Justificativa e objetivo desta pesquisa ............................................... 15

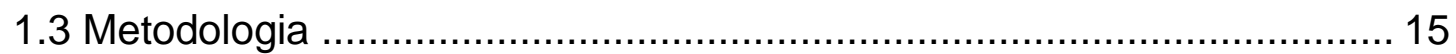

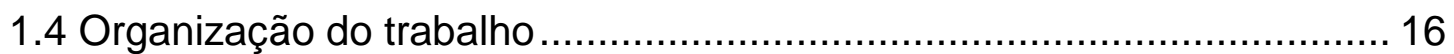

2. O CONCEITO DE MOBILIDADE SOCIAL ............................................... 18

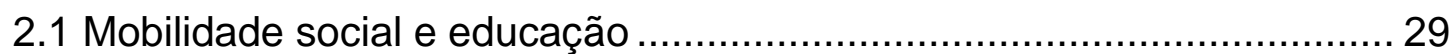

3. EDUCAÇÃO PROFISSIONAL E TECNOLÓGICA NO BRASIL.................. 36

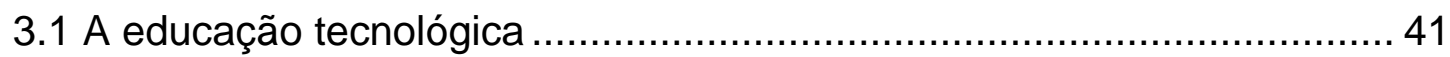

3.2 O papel do SENAI no contexto da educação profissional brasileira ....... 45

4. EDUCAÇÃO, HABILIDADES E COMPETÊNCIAS ................................. 47

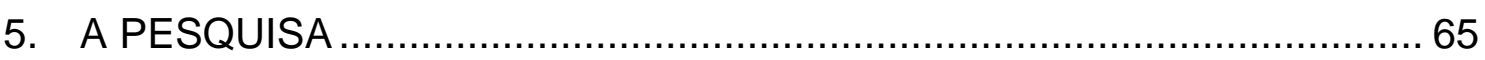

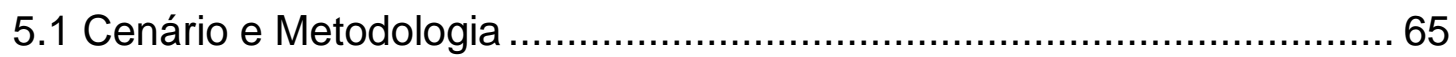

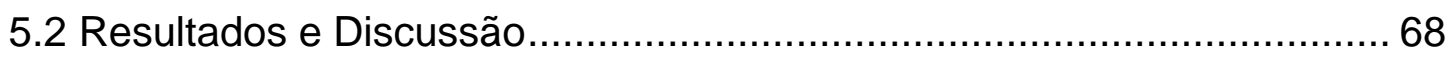

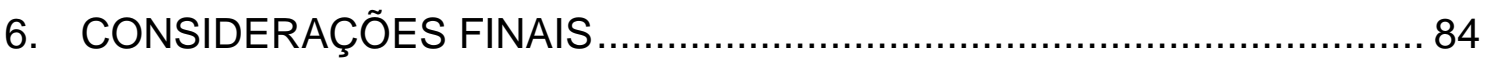

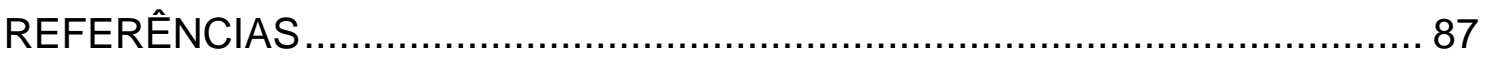

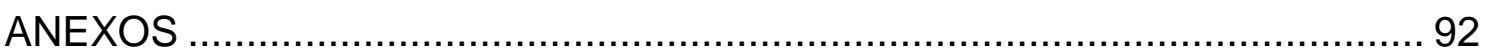




\section{INTRODUÇÃO}

Este trabalho apresenta uma pesquisa sobre o ensino-aprendizagem de moda na Faculdade de Tecnologia SENAI Antoine Skaf, subordinada ao Departamento regional de São Paulo do Serviço Nacional de Aprendizagem Industrial - SENAI, considerando os egressos do Curso Superior de Tecnologia em Produção de Vestuário no período de 2011 a 2015. A questão norteadora desta investigação é se esse evento - isto é, o fato de terem a oportunidade de realizar esse curso - pode, efetivamente, ter contribuído para o processo de mobilidade social desses estudantes.

As classes emergentes têm estado no foco de atenção da sociedade brasileira em função das mudanças econômicas ocorridas no país, que possibilitaram sua ascensão a novos hábitos de consumo. Nesse sentido, as empresas têm adaptado seus produtos, ou criado novos, apostando no aumento do consumo da chamada "nova classe média" brasileira, que na verdade, segundo Souza (2012), é uma "nova classe trabalhadora", já que o trabalho continua a ser o elemento central na vida dessas pessoas

Noronha e Barbosa (2016) pontuam que o trabalho é essencial à vida humana, porque ele é o mediador entre o homem e a natureza. As autoras afirmam, citando Marx, que a sociedade só pode ser compreendida a partir das relações de trabalho, pois "os meios de trabalho não são só medidores do grau de desenvolvimento da força de trabalho humano, mas também indicadores das condições sociais nas quais se trabalha" (MARX, 1985, p. 151, apud NORONHA; BARBOSA, 2016, p. 42).

O trabalho, na sociedade pré-industrial, foi o que possibilitou uma mudança na organização do sistema social vigente, já que, por meio do trabalho surgiu a possibilidade de construção de um sujeito autônomo, que separa sua vida pessoal das atividades que deve realizar para sobreviver. Um sujeito que tem a opção de escolha, que pode decidir o que deseja ser e fazer, o que leva, por sua vez, à possibilidade de mobilidade social, que não existia no modelo aristocrático, já que este impossibilitava qualquer questionamento de classe e trabalho (POSTER, 1979, apud NORONHA; BARBOSA, 2016). 
Neri (2011) afirma que o critério "renda" é ainda o que predomina na divisão de classes econômicas. Mas de acordo com Bourdieu (2007), a distinção entre as classes sociais não está atrelada apenas ao capital econômico. Para o autor, é por meio dos julgamentos de gostos e preferências, que são socialmente construídos, que a relação de classe social é estreitada. Nas sociedades modernas, o princípio da distinção é construído a partir da familiaridade e naturalidade dos indivíduos e grupos sociais com uma cultura legítima.

Noronha e Barbosa (2016) salientam, então, que para compreender as classes sociais, não se pode considerar apenas a renda e o consumo, mas também o estilo de vida e a visão de mundo de cada indivíduo. Pertencer a uma classe social não é somente gozar de privilégios e bens materiais ou poder transferi-los às futuras gerações. É também uma questão de transmissão de valores, e em relação a isso, as autoras reconhecem que o trabalho é central, pois estimula esses sujeitos a lutar por melhores condições de vida, mesmo nas situações sociais mais adversas.

No caso da nova classe trabalhadora brasileira, é necessário observar, além da distribuição de renda, o potencial de consumo, a geração de renda e as expectativas sobre o futuro (NERI, 2011). O autor destaca ainda que essa classe, ao ser incluída no sistema econômico, como produtora ou consumidora crescente de bens e serviços, desenvolveu práticas sociais e hábitos que antes eram considerados privilégios reservados às classes média e alta.

Nesse cenário, a possibilidade de acesso a um curso superior ganha destaque enquanto processo alavancador de evolução pessoal e mobilidade social, em função da capacitação para o trabalho e geração de renda, mas também pelo fortalecimento do capital cultural do indivíduo, já que "fazer faculdade" passou a ser um sonho de consumo não apenas em função da educação formal, mas também da imagem associada ao estudante universitário ou ao profissional de nível superior no Brasil, isto é, uma imagem de inteligência e sucesso.

Com isso, acentuou-se, a partir do ano 2000, uma tendência verificada já na década de 1990, de aumento da procura por educação formal de nível superior no Brasil, com destaque para a nova modalidade de cursos superiores de tecnologia, que permitem a obtenção da formação de nível superior em um tempo menor do que os bacharelados. Além disso, esses cursos têm uma 
característica de oferecer uma formação mais específica, voltada para as necessidades do mercado de trabalho.

Nesse contexto, o setor têxtil e moda, que até 1989 não contava com cursos de nível superior no Brasil, foi um dos primeiros a ser contemplado na oferta de cursos tecnológicos, que se intensificou a partir de 2000, e tornou-se rapidamente um dos mais procurados: fazer Moda entrou na moda!

\subsection{0 setor têxtil e vestuário no Brasil}

Algumas características, como a carência de mão de obra especializada e a grande possibilidade de atuar como empreendedor, inclusive empreendedor social (cooperativismo, associativismo, negócios sociais) e autônomo (já que a necessidade de investimentos para isso é baixa), acabaram por tornar o setor do vestuário bastante atraente como campo profissional.

No cenário da globalização, e buscando ampliar sua competitividade, a indústria brasileira do vestuário vem gradualmente incorporando novas tecnologias aos processos de fabricação. Essas transformações têm impacto significativo na formação da mão-de-obra e nas formas de gerenciamento dos processos produtivos. O setor conta com mais de 40 mil unidades de produção no Brasil, e a maioria desses estabelecimentos (79\%) se concentra nas regiões Sudeste e Sul do país.

A indústria têxtil é uma das mais antigas atividades industriais da humanidade e pode ser considerada uma das precursoras da Revolução Industrial. Mesmo atualmente, continua desempenhando um papel importante na economia mundial (ALVES, 2010).

No Brasil, o processo de industrialização iniciou-se com a indústria têxtil. Em 1864 o país já possuía 20 fábricas, com aproximadamente 15 mil fusos e 385 teares. Em 1881, este número cresceu para 44 fábricas e 60 mil fusos, gerando aproximadamente cinco mil empregos. Este crescimento permaneceu nas décadas seguintes, e às vésperas da I Guerra Mundial, havia 200 fábricas funcionando no Brasil e empregando 78 mil pessoas (LOBO, 2014).

Atualmente, a indústria têxtil e vestuário, ou melhor, a chamada "cadeia de valor têxtil e moda" (Figura 1), continua desempenhando um papel significativo na economia de diversos países. No Brasil, o setor ocupa um espaço 
significativo dentro da economia, como pode ser verificado nos dados referentes a 2015 e divulgados pela ABIT - Associação Brasileira da Indústria Têxtil em fevereiro de 2016 (PIMENTEL, 2016):

- Faturamento da Cadeia Têxtil e de Confecção: US\$ 39,3 bilhões, contra US\$ 53,6 bilhões em 2014.

- Exportações (sem fibra de algodão): US $\$ 2,38$ bilhões, contra US $\$ 1,18$ bilhão em 2014.

- Importações (sem fibra de algodão): US $\$ 5,93$ bilhões, contra US\$7,08 bilhões em 2014.

- Saldo da balança comercial (sem fibra de algodão): US\$ 4,8 bilhões negativos, contra US $\$ 5,9$ bilhões negativos em 2014 .

- Investimentos no setor: US\$ 869 milhões, contra US\$1.091 milhão em 2014.

- Produção média de confecção: 6,7 bilhões de peças (considerando não apenas o vestuário, mas também meias, acessórios e artigos de cama, mesa e banho), contra 6,1 bilhões de peças em 2014.

- Produção média têxtil: 1,8 milhão de toneladas, contra 2,2 milhões de toneladas em 2014

- Trabalhadores: 1,5 milhão de empregados diretos e 8 milhões se forem adicionados os indiretos e o "efeito renda", dos quais $75 \%$ são de mão de obra feminina, representando $16,7 \%$ dos empregos e $5,7 \%$ do faturamento da indústria de transformação, e sendo o maior empregador dessa mesma indústria, perdendo apenas para alimentos e bebidas (juntos).

No contexto desta pesquisa, é importante salientar que o setor é o segundo maior gerador do primeiro emprego no Brasil, contando com 32 mil empresas espalhadas por todo o país (considerando apenas os negócios formais). Vale acrescentar que o setor também é o quarto maior parque produtivo de confecção do mundo; o quinto maior produtor têxtil do mundo; o segundo maior produtor e terceiro maior consumidor de denim do mundo; e o quarto maior produtor de malhas do mundo. Além disso, o país é autossuficiente na produção de algodão, e é considerado o último país ocidental a deter a cadeia têxtil completa, desde a plantação de algodão e a produção das fibras, até os desfiles de moda, passando por fiações, tecelagens, beneficiadoras, confecções e varejo (PIMENTEL, 2016). 
Figura 1 - A Cadeia de Valor Têxtil e Vestuário

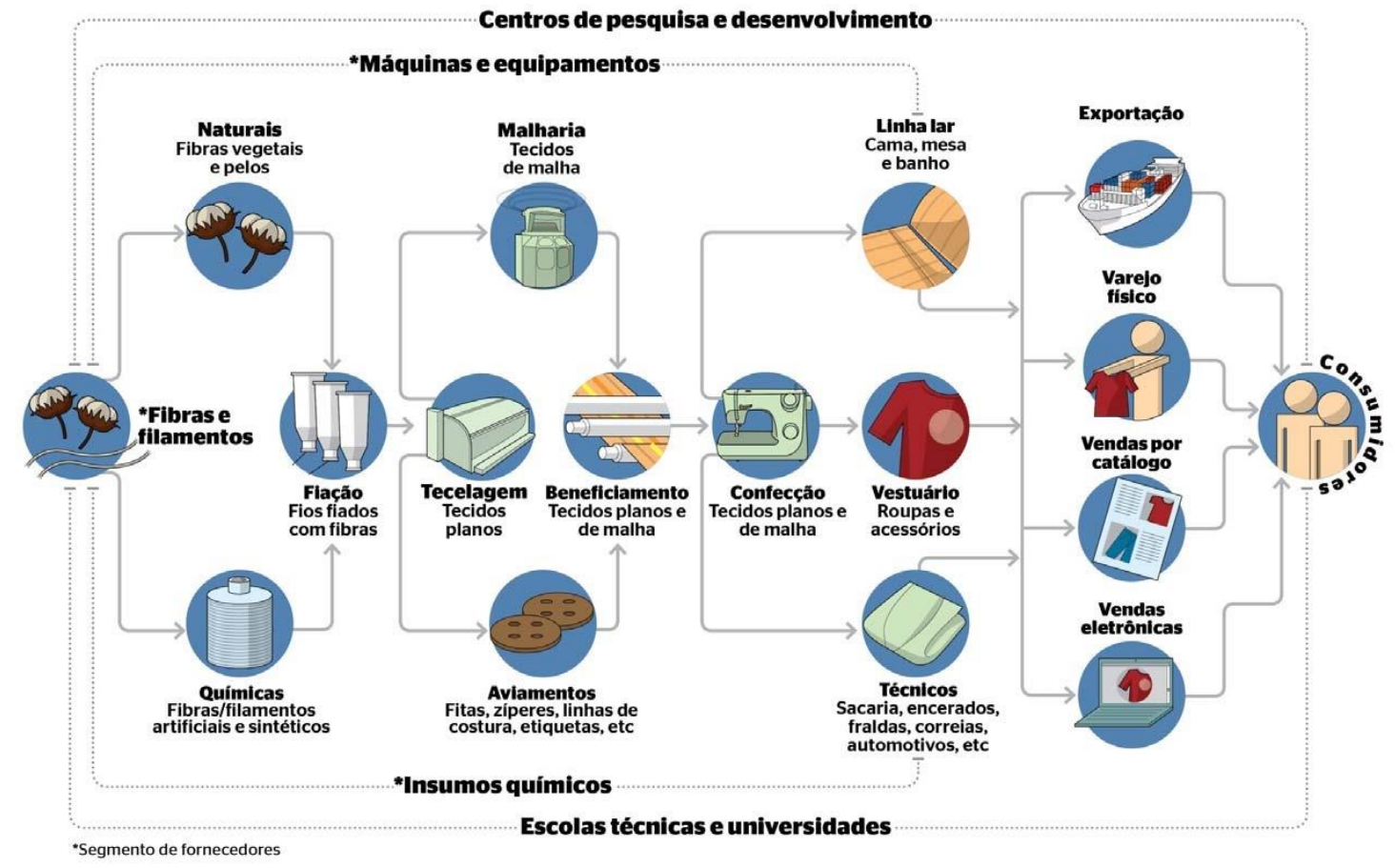

Fonte: Pimentel, 2016.

As novas tecnologias inseridas no cotidiano das organizações têm colaborado para o desenvolvimento mais dinâmico e eficiente de produtos e serviços, levando à valorização do conhecimento e de profissionais comprometidos com os valores e metas das organizações e o bem-estar da sociedade.

Em função das demandas da sociedade, novos produtos e processos estão em constante desenvolvimento, e a cadeia de valor têxtil e vestuário adaptou-se ao novo mercado, que é direcionado pela indústria da moda, requerendo fibras, tecidos, cores, estampas e acabamentos diferenciados. Assim, tem havido uma busca incessante por novas tecnologias e modernização do parque industrial têxtil e de vestuário.

Atualmente, a moda brasileira está classificada entre as cinco maiores promotoras de eventos e desfiles do mundo, e o país já conta com cerca de 100 instituições escolares que oferecem cursos de moda, desde escolas técnicas especializadas, até cursos técnicos e superiores (de tecnologia e bacharelados), oferecidos por faculdades, centros universitários e universidades. 


\subsection{Justificativa e objetivo desta pesquisa}

Nesse contexto, o surgimento de cursos superiores de tecnologia consolidou $\mathrm{o}$ interesse pela área e atraiu estudantes com perfil bastante diversificado, desde profissionais já atuantes no setor, até jovens recém-saídos do Ensino Médio.

A justificativa para a realização desta pesquisa foi a carência de estudos acadêmicos voltados à análise e discussão da formação profissional tecnológica no Brasil, a partir do início da década de 2000, quando esses cursos ganham volume e relevância no cenário do ensino superior brasileiro, especialmente os cursos da área de moda e vestuário.

Assim, o objetivo da pesquisa é contribuir para a análise sobre a educação tecnológica, com ênfase na área de moda e vestuário, discutindo a importância do processo de ensino-aprendizagem nessa área para a mobilidade social de seus estudantes.

A hipótese considerada no delineamento deste estudo foi a de que o ensino e a aprendizagem de moda, por parte de jovens e adultos oriundos das classes emergentes, por meio do modelo de Educação por Competências oferecido pelo SENAI, pode constituir-se efetivamente num meio de mobilidade social, uma vez que esse modelo torna-se mais significativo para o aluno porque propõe a construção do conhecimento a partir das reais demandas do mercado, além de oferecer uma formação intelectual ampla, voltada à formação do estudante autônomo e do profissional crítico e criativo.

\subsection{Metodologia}

Esta pesquisa foi realizada na Unidade SENAI Francisco Matarazzo, localizada no bairro do Brás, em São Paulo - SP, que abriga a Faculdade de Tecnologia SENAI Antoine Skaf, que por sua vez oferece o Curso Superior de Tecnologia em Produção de Vestuário.

É importante salientar que a Unidade é totalmente voltada para a área têxtil e vestuário, oferecendo cursos de aprendizagem industrial, técnicos e livres em ambas as áreas. Apenas o curso superior é único, dedicado à gestão 
industrial na área de vestuário. Este curso, que é oferecido em regime semestral, durante seis semestres (2.400 horas), recebe cerca de 240 matrículas por ano e forma, em média, 50 novos profissionais a cada ano.

O curso foi criado em 2002 e a primeira turma foi admitida no segundo semestre de 2003. Em 2007, o projeto do curso sofreu uma grande reformulação, passando a seguir a Metodologia por Competências que já era adotada nos cursos técnicos da instituição. A primeira turma a ingressar no curso já formatado por competências foi a do primeiro semestre de 2009, concluindo sua formação em dezembro de 2011. Por isso os participantes do estudo foram recrutados entre os formandos do período 2011-2015.

A amostra com a qual a pesquisa foi realizada foi definida a partir do número de alunos formados no período estudado (2011 a 2015). Nesses cinco anos, o curso teve, em média, 50 concluintes por ano, totalizando 250 concluintes no período. A amostra buscou abranger pelo menos $20 \%$ desse total.

Em relação à metodologia, este estudo foi delineado como uma pesquisa de caráter descritivo e exploratório. De acordo com Cervo e Bervian (2002, p. 67 ), "a pesquisa descritiva, em suas diversas formas, trabalha sobre dados ou fatos colhidos da própria realidade", observando, registrando, analisando e correlacionando fatos ou fenômenos sem manipulá-los.

Já a pesquisa exploratória, segundo Cervo e Bervian (2002), pode se constituir numa investigação por si só, ou ser o primeiro passo de uma pesquisa mais ampla. Sua principal característica é a possibilidade de o pesquisador familiarizar-se com o fenômeno a ser estudo, sem necessariamente levantar hipóteses. Os autores afirmam que o estudo exploratório é recomendado em situações em que há poucas abordagens acadêmicas disponíveis sobre o tema.

Como parte dos procedimentos descritivos e exploratórios, foram realizadas também pesquisa bibliográfica e documental, conforme será explicitado mais detalhadamente no capítulo 5 , que traz a apresentação e discussão dos resultados da pesquisa.

\subsection{Organização do trabalho}

Para efeito de organização do trabalho, considerou-se esta Introdução como capítulo 1, no qual são apresentadas informações sobre a cadeia de valor 
têxtil e vestuário no Brasil, como uma forma de desenhar o cenário maior no qual se situa este estudo específico, além da justificativa e objetivo geral da pesquisa.

No capítulo 2 é apresentado o conceito de mobilidade social, de forma descritiva, uma vez que a intenção deste estudo não é discutir o conceito, mas utilizá-lo como categoria de análise para os resultados da pesquisa.

O capítulo 3 traça um panorama histórico, com o objetivo de caracterizar a educação profissional e o seu papel no contexto educacional brasileiro, englobando o surgimento, desenvolvimento e caracterização dos cursos de formação de tecnólogos que, embora sejam cursos superiores, estão essencialmente ligados à educação profissional. Ainda nesse capítulo é descrito e caracterizado o SENAI, enquanto instituição educacional voltada ao ensino profissionalizante, e também enquanto objeto de estudo, já que a investigação aqui apresentada concentra-se num dos cursos dessa instituição.

O capítulo 4 busca apresentar e discutir o conceito de "competência" sob a ótica da educação, uma vez que a formação por competências é a principal característica do curso no qual foi realizada a pesquisa aqui apresentada. Também nesse capítulo é descrita a concepção da Metodologia por Competências adotada pelo SENAI, por meio da apresentação de alguns pontos do projeto pedagógico do Curso Superior de Tecnologia em Produção de Vestuário.

O capítulo 5 é dedicado à apresentação mais detalhada dos procedimentos metodológicos adotados no desenvolvimento da pesquisa, além dos dados coletados e da análise dos resultados, de acordo com categorizadores considerados relevantes.

Finalmente, o capítulo 6 apresenta as Considerações Finais sobre o estudo, propondo ainda novos questionamentos e caminhos possíveis de pesquisa acadêmica sobre o tema. 


\section{O CONCEITO DE MOBILIDADE SOCIAL}

O processo de estratificação social, que se refere à classificação hierárquica de grupos ou indivíduos numa escala, parece constituir-se numa característica universal das sociedades humanas. No entanto, esse processo assume diferentes formas conforme o tempo e o espaço em que ocorre.

A mobilidade social é um conceito intimamente ligado à questão da existência de extratos sociais, e também aos conceitos de espaço, distância e posição social. De acordo com Lakatos (1981, p. 226):

(...) A posição de um indivíduo, grupo ou fenômeno social é passível de localização no espaço social, através das relações que mantém com outro homem, grupo ou fenômeno social, selecionado como ponto de referência.

A autora aponta que essa localização é mais difícil que a localização geográfica, uma vez que não bastam coordenadas exatas, como latitude e longitude, para localizar alguém ou algo no espaço social. No entanto, completa:

(...) criou-se um sistema de coordenadas sociais que torna mais fácil a localização da posição social de um indivíduo. Consiste na determinação, em primeiro lugar, dos grupos específicos de que 0 indivíduo faz parte e suas exatas relações com estes grupos; em segundo lugar, verifica-se a relação que estes grupos mantêm entre si, no interior de uma população; por último, determina-se a relação desta população com as outras que existem no universo humano (LAKATOS, 1981, p. 227).

A autora explica ainda que os principais grupos que interessam na determinação da posição social de uma pessoa são aqueles que também fornecem os critérios para a determinação do status ${ }^{1}$, ou seja, os grupos de parentesco, raça, nacionalidade, posição econômica, de ocupação, de educação, de religião, de filiação política, de sexo e de idade.

Para chegar ao conceito de mobilidade social, Lakatos (1981) acrescenta ainda que o sistema de coordenadas sociais está baseado na totalidade de grupos existentes numa sociedade e na totalidade de suas relações entre si, constituindo-se num espaço multidimensional: o espaço social.

\footnotetext{
1 Status é o lugar ou posição que a pessoa ocupa na estrutura social, de acordo com o julgamento coletivo ou consenso de opinião do grupo. Portanto, o status é a posição em função dos valores sociais correntes na sociedade (LAKATOS, 1981, p. 92).
} 
Dentro desse espaço, os indivíduos ou grupos ocupam posições sociais, e a passagem de um indivíduo ou de um grupo de uma posição social para outra, dentro de um dado universo de grupos e estratos sociais, configura o movimento de mobilidade social.

Citando Sorokin (1927), a autora mostra ainda que a mobilidade pode ser social e cultural, e pode dar-se em sentido vertical ascendente ou descendente, ou em sentido horizontal:

\footnotetext{
Por mobilidade social entende-se toda passagem de um indivíduo ou de um grupo de uma posição social para outra, dentro de uma constelação de grupos e estratos sociais. Por mobilidade cultural entende-se um deslocamento similar de significados, normas, valores ou veículos (SOROKIN, 1927, p. 629, apud LAKATOS, 1981, p. 229).
}

A mobilidade social e cultural horizontal refere-se à passagem de um indivíduo (ou de um conjunto de significados, normas, valores ou veículos) de um grupo social para outro, situado no mesmo nível ou estrato. E a mobilidade social e cultural vertical significa essa mesma passagem, mas em sentido ascendente ou descendente, isto é, em direção a grupos sociais situados em estratos ou níveis situados acima ou abaixo do nível original.

Explicando as características da mobilidade social, Lakatos (1981) afirma que ela pode ocorrer: a) entre comunidades (ou grupos territoriais), dando como exemplo a migração rural-urbana; b) entre grupos familiares (parentesco), mobilidade esta que pode ocorrer em função de casamentos, divórcios, adoções e outras formas de agregação; c) entre grupos ocupacionais, isto é, ligados à profissão, chamando a atenção para dois fatos: o primeiro, de que esse tipo de mobilidade é um processo universal e contínuo, mas ocorre em nível muito baixo em sociedades fortemente marcadas pela divisão em castas ou estamentos, e em nível muito mais alto nas sociedades de classes, e o segundo, de que nas sociedades industrializadas e urbanizadas, a taxa de mobilidade social do tipo ocupacional varia de acordo com o nível de especialização e habilitação, isto é, está fortemente ligada à questão da educação e treinamento da mão-de-obra; d) entre grupos religiosos, em função da saída ou chegada de novos membros; e) entre partidos, agremiações e grupos de caráter político, também em função da saída e chegada de novos membros, por motivos diversos; f) entre Estados nacionais, em função dos fluxos migratórios. 
A respeito da mobilidade social vertical, Lakatos (1981) afirma que todo grupo organizado (e, portanto, estratificado) apresenta algum grau de mobilidade vertical. Não existe nenhum grupo em que essa mobilidade seja totalmente livre de obstáculos ou regulações, mas o nível de mobilidade vertical varia muito entre os diferentes grupos sociais e também em relação ao período histórico. Finalmente, a autora pontua que:

\begin{abstract}
Nas populações ocidentais, principalmente, os grupos e estratos diferentes apresentam-se ligados e entrelaçados através do intercâmbio (mobilidade vertical e horizontal) dos membros e seus descendentes e, em consequência, as linhas de separação entre os grupos e estratos não são nítidas. Os filhos de diferentes pais (e, às vezes, pertencentes à mesma família), membros de grupos (políticos, econômicos, ocupacionais, religiosos, etc.), participantes do mesmo estrato, dispersam-se por outros; assim, os quadros de todos os estratos (na maioria das sociedades ocidentais) são recrutados entre os filhos de indivíduos que pertencem a estratos diferentes, muitas vezes altamente dessemelhantes: podem encontrar-se, nas camadas superiores, filhos de pessoas que ocupam estratos inferiores e viceversa (LAKATOS, 1981, p. 235).
\end{abstract}

Compreende-se, assim, que a discussão do tema "mobilidade social" é bastante complexa, mas necessária, uma vez que está ligada a todos os movimentos de um indivíduo no espaço social, o qual, por sua vez, é sempre estratificado.

Discutindo a estratificação social, Stavenhagen (1999, p. 282) afirma que:

Ao considerar os diferentes critérios de estratificação é necessário distinguir claramente aqueles que são quantitativos, e que podem ser representados por gradações ou curvas (tais como o nível de renda ou a educação), e os que são qualitativos. Estes, por sua vez, são de dois tipos: os critérios objetivos (tais como a posse ou não posse de certos bens, o tipo de trabalho desempenhado na sociedade, o desempenho de funções diretoras ou subalternas, etc.) e os critérios que, ainda que objetivos, estão baseados, sem dúvida, em avaliações subjetivas, tais como o prestígio de certas ocupações ou dos diferentes grupos raciais ou étnicos (critério importante nas sociedade com problemas de minorias).

A partir disso, o autor pontua que "a mobilidade social implica um movimento significativo na posição econômica, social e política de um indivíduo ou de um estrato" (STAVENHAGEN, 1999, p. 285), mas chama atenção para o fato de que o que se estuda como mobilidade social é, na verdade, o movimento referente aos indivíduos, já que a mudança nos estratos sociais tem mais a ver com evolução ou desenvolvimento social. E acrescenta que a discussão sobre 
mobilidade social deve basear-se, principalmente, no fato de que os sistemas de estratificação do mundo moderno não são rígidos e permitem a passagem de um indivíduo de um status ou de uma classe para outra.

O autor também destaca as definições correntes de "classe social", que é o nome que geralmente se dá a um estrato ou camada, dentro de uma sistema de estratificação. Ele lembra que a concepção estrutural e dinâmica das classe sociais foi desenvolvida por Marx e Engels e que a literatura recente sobre 0 tema (na qual o conceito de classe não foi inteiramente absorvido pelo de estratificação) se inspira, invariavelmente, na concepção marxista; no entanto, ele prossegue afirmando que o conceito não foi completamente desenvolvido pelo autor de O Capital.

Por isso, Stavenhagen (1999, p. 287) pontua que:

Se os estratos, como vimos ("camadas" ou "classes"), no sentido de
uma estratificação, constituem categorias descritivas, estáticas, as
classes sociais (...) constituem categorias analíticas. Isto é, fazem parte
da estrutura social, com a qual mantêm relações específicas. (...) Mas
a classe social é também, antes de tudo, uma categoria histórica. Isso
quer dizer que as classes estão ligadas à evolução e ao
desenvolvimento da sociedade: encontram-se nas próprias estruturas
sociais que as caracterizam.

Nesse sentido, o autor enfatiza que um dos maiores problemas da Sociologia, e um dos que mais tem dividido as diversas correntes sociológicas, é justamente o estabelecimento de critérios para distinção das classes, lembrando que um dos aspectos fundamentais do conceitos de classes é que elas não existem de forma isolada, mas apenas como parte de um sistema de classes, isto é, as classes sociais só existem em relação umas com as outras, ou seja, o que define e distingue as diversas classes são as relações específicas que se estabelecem entre elas.

Finalmente, o autor lembra também que, dada a extrema diversidade presente nas sociedades humanas, essas relações tendem a ser muito diferentes, se forem comparadas diferentes sociedades, seja essa comparação feita no mesmo ou em diferentes tempos históricos. No entanto, Stavenhagen (1999) salienta que é possível observar relações que ele chama de fundamentais ou estruturais, que são determinadas pelos interesses objetivos de cada classe, como resultado das posições específicas que elas ocupam no processo produtivo, isto é, nos mecanismos de produção e manutenção da riqueza de uma 
sociedade. Para ele, as relações entre as classes são sempre de oposição, e essas relações de oposição é que permitem a mudança das estruturas sociais. Ou seja: ainda que não possam se enfrentar em termos de igualdade, o "enfrentamento" se dá por outros meios, como a busca dos indivíduos de classes mais baixas por melhores condições de trabalho e renda, e a luta pela manutenção e melhoria de suas próprias condições que também motiva os integrantes das classes mais altas.

Essa dinâmica constitui a chamada fluidez social. A esse respeito, Ribeiro (2014, p. 179-180) afirma que:

\begin{abstract}
Em estudos comparativos ao longo do tempo ou entre países, é possível verificar diferenças no grau de fluidez social. Um estudo recente sobre o Brasil revela que houve diminuição da desigualdade de oportunidades entre as décadas de 1970 e 2000. Por outro lado, permitem determinar as principais barreiras à mobilidade intergeracional, que, por sua vez, também podem ser vistas como divisões básicas da estrutura de classes de uma sociedade. As principais clivagens na estrutura de classes não são dadas apenas pelos recursos (econômicos, educacionais e sociais) disponíveis, mas também pela forma como estes recursos contribuem para a reprodução intergeracional das classes sociais.
\end{abstract}

Em função disso, o autor propõe um esquema com sete grupos de classe para analisar a estrutura social brasileira, salientando que atualmente há, no Brasil, um enorme debate sobre a expansão das classes médias, em geral observadas em termos de renda média. A definição sociológica de classes sociais enfatiza distinções na posição que os trabalhadores ocupam na estrutura produtiva em termos de propriedade, qualificações e trabalho manual, por um lado, e das principais barreiras à mobilidade intergeracional como fontes de estruturação de classes, por outro lado. Assim, a ideia de classes médias nos estudos sociológicos sobre estratificação social depende de uma série de análises e definições envolvendo a estrutura ocupacional e os padrões de mobilidade intergeracional.

O autor complementa afirmando que:

Os dados que analiso permitem definir claramente estas ocupações e verificar quais são as principais barreiras à mobilidade. Dessa forma, as análises aqui desenvolvidas permitem verificar em que medida houve uma expansão das classes médias entre os anos 1970 e 2000, considerando diversos aspectos das classes sociais, inclusive os padrões de mobilidade. Para complementar essas análises, também descrevo o efeito mediador, entre origem e destino de classe, da educação alcançada pelos indivíduos (RIBEIRO, 2014, p. 182). 
Assim, compreende-se que a renda não pode ser a única medida do pertencimento de classe de um indivíduo. Ribeiro (2014) chama a atenção para o fato de que as classes sociais, tradicionalmente, devem ser estudadas e definidas também em termos das relações de trabalho em que as pessoas se encontram, e de como essas relações determinam também a identidade cultural e as chances de vida dos indivíduos.

O autor pontua ainda que:

De fato, os estudioso da estratificação social sabem que o capital cultural (geralmente mensurado pela educação dos pais e das pessoas) e a divisão do trabalho (posição na estrutura produtiva) são importantes para definir a distribuição de classe das sociedades. Essas pesquisas se colocam em oposição à de Neri (2011), na medida em que indicam que a estrutura e cultura de classe não podem ser reduzidas à renda, que a despeito de ser um indicador importante não pode ser a única forma de definir a estrutura de classes das sociedades. A estratificação social é multidimensional em qualquer sociedade, ou seja, educação, cultura de classe, ocupação, posição na estrutura produtiva e renda são dimensões distintas que estão estatisticamente correlacionadas, mas não perfeitamente alinhadas (RIBEIRO, 2014, p. 184).

No Brasil, segundo Machado (2012), nos últimos anos, o tema da mobilidade social ganhou a mídia e o debate público brasileiro. Em um contexto de estabilização e crescimento econômico, a ascensão social de uma parcela significativa da população tem merecido destaque: a "classe C", ou "nova classe média", tornou-se a protagonista da economia, alterando significativamente as estratégias de mercado e a configuração do consumo no país, com milhões de pessoas tendo acesso a bens e serviços que antes eram exclusividade de uma minoria.

Contestando a real existência dessa "nova classe média" no Brasil, Ribeiro (2014, p. 193) afirma que:

Os estudos de mobilidade de classe fazem uma distinção entre taxas absolutas e relativas de mobilidade. As taxas absolutas refletem a disparidade entre as distribuições de classes de origem e de destino (...). Essas distribuições tendem a ser muito diferentes quando as sociedades passam por mudanças estruturais em períodos curtos de tempo. A diferença entre as distribuições de classe de origem (dos pais) e de destino (dos filhos) são muito acentuadas no Brasil, exatamente porque a industrialização e a urbanização ocorreram em um curto período de tempo no país, principalmente nas décadas de 1960 e 1970. Ecos dessa mudança ainda podem ser percebidos nas taxas de mobilidade intergeracional até 2008. Usando um esquema 
com seis classes sociais, Costa Ribeiro (Ribeiro, 2012) mostrou que, para os homens, em 1973, o índice de mobilidade total era de 55,3\%, em 1982 de 57,7\%, em 1988 de 60,7\%, em 1996 de 60,9\%, e em 2008 de $67,3 \%$. Esses percentuais representam a quantidade de indivíduos que está em uma classe de destino diferente da sua classe de origem.

Dessa forma, o autor procura enfatizar que o simples aumento da renda e do consumo, fenômeno ocorrido no país a partir de meados da década de 1990, não podem ser adotados isoladamente como sinônimo de mobilidade social dos indivíduos (ou de mudança social na sociedade como um todo), e salienta as questões relativas à educação e à ocupação profissional como indicadores complementares, indissoluvelmente ligados e absolutamente fundamentais para a explicação e compreensão da mobilidade social. $O$ autor contesta as taxas absolutas de mobilidade, e também questiona o modelo de mobilidade da sociedade brasileira.

\begin{abstract}
Há dois problemas com as taxas absolutas de mobilidade. Primeiro, elas não mensuram a associação estatística entre classes de origem e de destino. Essa mensuração é importante para definir a vantagem relativa que indivíduos com diferentes classes de origem têm de ascender socialmente. Por exemplo, se a classe de profissionais e administradores quadruplicar de tamanho entre a geração dos pais e a dos filhos, e todos os filhos de profissionais (em média 2) se tornarem profissionais, teremos que pelo menos metade dos profissionais viriam necessariamente de baixo. Do ponto de vista das taxas absolutas, haveria bastante mobilidade, mas do ponto de vista das taxas relativas haveria uma enorme associação entre origem e destino de classe. Os profissionais teriam certeza de que seus filhos se tornariam profissionais. Em outras palavras, neste caso, a desigualdade de oportunidades seria a maior possível. Em segundo lugar, a análise das taxas relativas de mobilidade social permite definir mais detalhadamente qual o padrão ou regime de mobilidade de classe que caracteriza uma determinada sociedade, ou seja, quais são as principais barreiras e qual o grau de fechamento social. Será que o regime de mobilidade de classe no Brasil segue um padrão topológico, com classes se opondo e se separando em diferentes dimensões, ou hierárquico, com classes se separando ao longo de uma única hierarquia? (RIBEIRO, 2014, p. 193-194)
\end{abstract}

Analisando a sociedade brasileira a partir de diversos modelos sociológicos de avaliação da estratificação e da mobilidade social, Ribeiro (2014) chegou à conclusão (entre outras) que a estrutura social brasileira é muito rígida, ao contrário do que apontam outros estudos sobre o fenômeno rotulado de "nova classe média".

As análises apresentadas nessa seção levam a algumas conclusões importantes sobre o padrão de associação entre classes de origem e de destino no Brasil. Primeiro, os modelos que melhor se ajustam aos 
dados, tanto para homens quanto para mulheres, são aqueles que especificam uma hierarquia entre todas as classes, e não apenas entre alguns grupos de classe. O padrão vertical, e não o topológico, é o que melhor descreve o caso brasileiro. Segundo, há alta propensão para imobilidade, principalmente na classe de profissionais e administradores $(\mathrm{I}+\mathrm{Il})$, que é a hierarquicamente mais alta, ou seja, a elite tem forte propensão para transmitir sua posição de classe para seus filhos. Esse padrão, com hierarquia e imobilidade no topo, indica que a estrutura social brasileira é muito rígida. Há muita mobilidade social em termos absolutos, como indiquei no primeiro parágrafo desta seção, mas forte associação entre classe de origem e de destino, como mostrei acima. Em outras palavras, a mudança rápida na estrutura de classes brasileira entre as gerações de pais e de filhos levou muitos filhos a experimentarem mobilidade social ascendente, mas aqueles que já se encontravam em classes hierarquicamente superiores foram capazes de garantir em larga medida essas posições superiores para seus filhos. Por exemplo, a classe de profissionais e administradores (I+II) é constituída por muitas pessoas que vieram de baixo, mas a grande maioria dos filhos de profissionais e administradores $(\mathrm{I}+\mathrm{II})$ permaneceu na mesma classe de seus pais (origem). (RIBEIRO, 2014, p. 204-205)

Bresser-Pereira (1974) afirma que a igualdade de oportunidade é realmente um dos grandes sonhos de todas as sociedades modernas, ao constatar que a mobilidade social está intimamente relacionada com o processo de desenvolvimento econômico ou, mais especificamente, com o processo de racionalização econômica e social, representado pelo surgimento do capitalismo e pela consequente crise dos sistemas sociais tradicionais. De acordo com o autor, as sociedades tradicionais, quando ultrapassam o nível das comunidades primitivas (até um certo ponto, mesmo nesse nível) organizavam-se em sistemas de estratificação rígidos, em que o poder e os privilégios eram prerrogativas familiares, que nasciam com os indivíduos (eventualmente, por direito divino) e eram transmitidos seus filhos. Nas sociedades assim organizadas, não há racionalidade no processo de distribuição das funções sociais.

A racionalização do processo social vem, de acordo com o autor, a partir da Revolução Comercial e, depois, da Revolução Industrial, com a emergência do capitalismo e o desenvolvimento de uma ideologia liberal, porque a burguesia emergente colocou em questão a rigidez da estratificação social, em defesa de seu próprio interesse de subir socialmente, e em nome de maior racionalidade e justiça do processo social.

Com o capitalismo e, particularmente, com a revolução industrial capitalista, surgiu o conceito moderno de desenvolvimento econômico, e a ele, imediatamente, se ligou um certo grau de mobilidade social que garantisse aos mais capazes - ou, mais precisamente, a uma parcela 
dos mais capazes - a motivação para o trabalho produtivo e a possibilidade de ocupar as posições mais importantes da sociedade (BRESSER-PEREIRA, 1973, p. 19).

Mas essa não foi uma mudança radical: "O capitalismo simplesmente, reorganizou e tornou mais flexível o sistema de privilégios, deslocando seu eixo dos fatores tradicionais para os fatores econômicos", afirma o autor, para complementar (BRESSER-PEREIRA, 1973, p. 20):

(...) deixando claro que desenvolvimento econômico e um certo grau de mobilidade social estão indissoluvelmente ligados. 0 desenvolvimento econômico é, ao mesmo tempo, causa e consequência da mobilidade social. À medida que aumenta a produtividade social, que a tecnologia se desenvolve, que a sociedade se moderniza e se racionaliza, a mobilidade social tende a aumentar. Em contrapartida, esse aumento de mobilidade tende a estimular 0 desenvolvimento econômico.

Compreende-se, assim, que o autor considera que a mobilidade e o desenvolvimento econômico e social estão reciprocamente relacionados, e que esse relacionamento abrange e se manifesta de diferentes formas:

a) em primeiro lugar, a sociedade industrial é essencialmente móvel do ponto de vista psicológico e quanto ao seu marco normativo. Com respeito ao primeiro, pressupõe uma particular plasticidade mental e capacidade de inovar e aceitar inovações; quanto ao segundo aspecto, requer a institucionalização da mudança, que se converte em um aspecto normal e esperado; b) em termos mais estritos, a sociedade industrial supõe um alto grau de mobilidade social vertical e um sistema de estratificação adequado para tal objetivo; também outras formas de mobilidade - em particular, horizontal e geográfica - são necessárias; c) a transição de um tipo pré-industrial de sociedade à sociedade industrial requer, tanto em suas fases iniciais como em suas fases posteriores, um certo grau de mobilidade nas formas, setores $e$ intensidade adequados; d) o desenvolvimento propriamente dito, uma vez iniciado, produz mudanças de estrutura que se traduzem em um alto grau de mobilidade (BRESSER-PEREIRA, 1973, p. 20).

O autor pondera, no entanto, que a mobilidade social não pode ocorrer de forma isolada; ela precisa de uma redução na diferenciação social. Ele propõe que se imagine uma sociedade altamente estratificada e, ao mesmo tempo, com alto grau de mobilidade social, em que os indivíduos estivessem permanentemente subindo e descendo na escala social. Nesse caso, diz Bresser-Pereira (1973), provavelmente se veria surgir uma classe de indivíduos amargurados e frustrados, que facilmente entrariam em conflito com o resto da sociedade. Esta situação, de acordo com o autor, se acentuaria à medida que 
os desníveis sociais fossem maiores e maior fosse a perda de poder, prestígio e privilégio dos que caíssem na escala social. Com isso, ele conclui que:

(...) um grande aumento da mobilidade social, sem uma correspondente redução nos desníveis existentes no sistema de estratificação social, poderá aumentar, ao invés de diminuir, os problemas sociais existentes (BRESSER-PEREIRA, 1973, p. 20).

Propondo uma discussão sobre a centralidade do trabalho na vida da "nova classe média" brasileira, Noronha e Barbosa (2016) afirmam que o novo capitalismo torna o trabalho "flexível", exigindo do trabalhador que seja ágil e que esteja aberto a mudanças e disposto a assumir riscos. Nesse sentido, as autoras afirmam ainda que o "capitalismo flexível" criou instituições maleáveis, porém tal flexibilidade concentrou-se mais nas forças que condicionam as pessoas. Elas observam que o fim da carreira trabalhista provocado pelas mutações do capitalismo gera ansiedade no trabalhador, já que ele não sabe mais que caminho seguir.

Por trás de todas essas mudanças do capitalismo, há sempre uma violência simbólica, uma violência invisível, dizem Noronha e Barbosa (2016). Para Bourdieu (2007), existe, no novo capitalismo, uma dominação simbólica que legitima a ideologia da igualdade de oportunidades. Dessa maneira, o capitalismo contemporâneo naturaliza a acumulação de capital e torna suas formas de legitimação imperceptíveis à sociedade. Sem essa dominação simbólica, não existiria o capitalismo, e a economia não se legitimaria (Bourdieu, 2007; Souza, 2012).

A dominação simbólica do capitalismo está atrelada, principalmente, à divisão de classes. No capitalismo contemporâneo, a possível superação do conflito de classes é desvelada por Bourdieu (2007), que reafirma a importância da distinção no jogo social de dominação, que permite às classes dominantes se legitimar. A luta de classes continua no novo capitalismo, uma vez que o maior segredo da dominação social do capitalismo é a existência de classes sociais (Bourdieu, 2007). (NORONHA; BARBOSA, 2016, p. 45)

O próprio Bourdieu (2007) observa que a distinção entre as classes sociais não está atrelada apenas ao capital econômico. O princípio das desigualdades sociais reside também na lógica de aquisição e reprodução do capital social. Para o autor, é por meio dos julgamentos de gostos e preferências, que são socialmente construídos, que a relação de classe social é estreitada. 
Nas sociedades modernas, o princípio da distinção é construído a partir da familiaridade e naturalidade dos indivíduos e grupos sociais com uma determinada cultura.

No caso da nova classe trabalhadora brasileira, é necessário observar, além da distribuição de renda, também o potencial de consumo, a geração de renda e as expectativas sobre o futuro (Neri, 2011), para determinar se essa classe realmente está vivenciando um processo consistente de mobilidade social.

Em relação às mudanças ocorridas no papel desempenhado pelo trabalho na vida das pessoas, ao longo da história, Pochmann (2012, 494-495) afirma que:

A partir do final do século 20 , nota-se que a emergência da sociedade pós-industrial torna-se compatível com o surgimento de novas formas de valorização do trabalho humano para além da obrigação estrita pela sobrevivência. A crescente postergação do ingresso dos jovens no mercado de trabalho e a maior redução no tempo do trabalho dos adultos, em combinação com a ênfase no ciclo educacional ao longo da vida, representam novas possibilidades para o trabalho no mundo, especialmente quando a expectativa de vida pode se aproximar dos 100 anos de idade.

O autor complementa afirmando que:

Desde o último quartel do século 20 que se encontram em curso inéditos requisitos da formação de um novo trabalhador, mais condizentes com as alterações no conteúdo e nas condições de produção e gestão em rede por empresas cada vez mais internacionalizadas. Por conta de possível inadequação entre demanda de trabalho mais exigente e oferta de trabalhadores com menor preparação, os requisitos de qualificação profissional e elevação das habilidades para o exercício laboral tornaram-se crescentes, cada vez mais distantes das tradicionais sistemas de educação e formação profissionais herdados da sociedade urbanoindustrial (POCHMANN, 2012, p. 498).

Considerando as visões dos autores apresentados até aqui, parece possível afirmar que, quando a mobilidade social está ligada ao trabalho, a questão da educação revela-se fundamental, uma vez que, por meio dela, o trabalhador se torna mais qualificado, aumentando suas possibilidades de ascenção social, principalmente na nova realidade laboral discutida por Pochmann (2012). 


\subsection{Mobilidade social e educação}

Saviani (2012, p. 11), discutindo a natureza e a especificidade da educação, afirma que "o que diferencia o homem dos outros animais é o trabalho", complementando que "dizer, pois, que a educação é um fenômeno próprio dos seres humanos significa afirmar que ela é, ao mesmo tempo, uma exigência do e para o processo de trabalho, bem como é, ela própria, um processo de trabalho".

Apontando o fato de que o aumento dos índices de emprego e de renda não são suficientes para a formação de uma nova classe média, mas sim de uma nova classe trabalhadora (já que muitas dessas famílias continuam morando nas periferias dos grandes centros, por exemplo, e não têm possibilidade de aquisição de patrimônios duradouros e valiosos), Noronha e Barbosa (2016) ponderam que, para esses cidadãos, o trabalho continua sendo o elemento central e transformador de suas vidas, porque permite também acesso a bens que antes eram restritos a uma pequena parcela da população.

Mas o mais importante, segundo as autoras, é que, contrariando o senso comum, esses trabalhadores não só consomem carros, celulares, televisões; pelo contrário. De acordo com elas, o principal item de consumo dessas pessoas é a educação, porque esses trabalhadores acreditam que, por meio da educação, poderão conquistar melhores lugares no mundo do trabalho.

De acordo com Bernstein (1996, p. 215):

Durante o século XX, com o capitalismo de transição, passam a existir fortes vínculos entre educação e o campo de produção, advindos das novas técnicas de gerência e de produção e das novas forças de produção que se desenvolveram no último quarto de século: eletrônica, controle computadorizado, bioengenharia. Entretanto, globalmente, a educação tenderá, mais provavelmente, a atuar para manter as relações estruturais entre grupos de classe, embora mudando a relação estrutural entre indivíduos através do sucesso e do fracasso seletivo. A educação, oficialmente, celebra e ideologiza indivíduo, embora, na realidade, ela obscureça as relações que mantém entre os grupos sociais. O vínculo entre educação e produção, reforçado pela igualdade de oportunidade e pela mobilidade através da educação, é mais ideológico que real em seus efeitos, especialmente para os grupos minoritários.

O autor completa afirmando que a educação, nesse período, é vista, ideologicamente, como possibilidade de mobilidade social e como meio de promoção de oportunidades iguais no que se refere ao campo de produção. 
Entretanto, ele pondera que há uma contradição aí: as últimas décadas do século $\mathrm{XX}$ foram marcadas pelo desemprego estrutural, associado à nova revolução nas comunicações, à microeletrônica e à globalização. Nesse contexto, o campo educacional e o campo econômico estreitaram seus vínculos, sendo que o fracasso da economia acaba por ser atribuído à impossibilidade da educação em aproximar-se do mundo do trabalho. A educação torna-se mais dependente das necessidades do campo econômico e mais dirigida pelos princípios derivados desse campo.

Ribeiro (2014, p. 205-206) afirma que:

A educação é o principal canal de mobilidade social nas sociedades
modernas. Pessoas com mais escolaridade não só tendem a ser mais
produtivas como também têm acesso a diversas ocupações que
exigem qualificação específica. Por exemplo, não é possível ser um
médico ou um torneiro mecânico sem ter as qualificações necessárias
para exercer essas funções. Portanto, as transmissões das posições
ocupacionais de pais para filhos não se dão de forma direta, mas sim
através das qualificações adquiridas pelos filhos no sistema
educacional. As possíveis superações das desvantagens de origem de
classe também se dão, em larga medida, através da educação formal
adquirida.

Exemplificando, o autor afirma que filhos de pessoas sem qualquer escolaridade e com posições de classe mais baixas têm a possibilidade de ascender, principalmente na medida em que adquirem qualificações educacionais. De acordo com diversas teorias em ciências sociais, a educação é o principal mecanismo de mobilidade social.

Em sua pesquisa sobre a mobilidade social e a estrutura de classes no Brasil contemporâneo, Ribeiro (2014) conclui que a educação é importante tanto para alcançar ou se manter numa classe, quanto para alcançar mobilidade ascendente entre as classes. $O$ autor afirma que este padrão indica que a educação diminui consideravelmente as vantagens de classe, mas não elimina completamente os efeitos das classes de origem nas de destino, porque continua havendo desigualdade de oportunidades mesmo quando se leva em conta a educação, ou seja, há outros mecanismos de reprodução de classe que não passam pelo sistema educacional.

Esses resultados indicam que, embora a educação seja um forte redutor da desigualdade de oportunidades, ela não é o único fator determinando estas desigualdades. Políticas de expansão educacional e de equalização do acesso aos diferentes níveis educacionais tendem 
a ter um forte impacto na desigualdade de oportunidades, mas há outros fatores que devem ser levados em conta. A associação direta entre classes de origem e destino, que permanece existindo para homens e mulheres mesmo quando se leva em conta a educação alcançada, pode ser consequência de diversos mecanismos. Talvez, parte da associação se deva a algum diferencial de motivação ou esforço. Não é possível descartar a hipótese de que alguns indivíduos sejam mais motivados do que outros e que isso leve a diferencial de mobilidade. Se estas características estiverem de alguma forma associadas à classe de origem dos indivíduos, então parte da associação entre origem e destino que mostrei depende deste diferencial em esforço e motivação. (RIBEIRO, 2014, p. 208).

O autor sugere que outras hipóteses também relevantes são as de que haja redes de contato social favorecendo pessoas com origens nas classes mais altas, e que pessoas com origens nas classes mais baixas sofram discriminação no mercado de trabalho. Ambos os mecanismos contribuiriam para a permanência da associação entre origem e destino de classe que as análises revelam, mesmo quando incluída a educação nos modelos estimados.

Lemos, Dubeux e Pinto (2009) destacam o fato de que, nos últimos anos, a qualificação profissional tem sido alardeada como um diferencial para a inserção no mercado de trabalho dos egressos de cursos de graduação. Os autores consideram que, com base em premissas relacionadas à teoria do capital humano, considera-se o investimento em educação estratégico para impulsionar a ascensão social dos indivíduos e potencializar o crescimento econômico da sociedade.

No entanto, analisando o estudo de Bourdieu (2007) a respeito da mobilidade social da sociedade francesa na década de 1970, eles questionam a relação causal entre formação e empregabilidade, na medida em que o estudo de Bourdieu (assim como o de Ribeiro, ambos já citados aqui) revela outros vetores que influenciam a ascensão social dos indivíduos.

Tanto Ribeiro (2014) quanto Bourdieu (2007), além de outros autores que estudam o tema, pontuam que pertencer às classes econômica e culturalmente mais favorecidas é uma garantia maior de acesso a posições de maior potencial no mercado de trabalho.

Conduzindo uma investigação com 98 formandos e egressos de um curso de administração de empresas de uma instituição de ensino superior localizada no Rio de Janeiro, Lemos, Dubeux e Pinto (2009) afirmam que foi possível identificar relações entre as origens desses egressos e sua inserção no mercado 
de trabalho, ligando a bagagem cultural e econômica de sua família às empresas e aos postos aos quais eles tiveram acesso.

A rápida expansão dos sistemas educacionais nas economias capitalistas e socialistas e a importância que passou a ser atribuída à educação como fator de integração social e de propulsão do desenvolvimento econômico criaram as condições para o surgimento, entre as décadas de 1950 e 1960, de uma disciplina para estudar esse fenômeno, a Economia da Educação, e de uma teoria capaz de explicar as relações entre educação e desenvolvimento, a Teoria do Capital Humano. Elaborada por Theodore Schultz ${ }^{2}$, essa teoria propõe uma revisão dos conceitos clássicos de capital e trabalho, argumentando que não se trata de fatores imutáveis, pois o trabalho poderia configurar-se em recurso maleável, capaz de fazer crescer a economia, na medida em que se valorizava, mediante investimentos em educação.

A proposição fundamental de Schultz (1967, apud LEMOS; DUBEUX; PINTO, 2009) é que, por intermédio do investimento em educação, as pessoas valorizam suas capacidades e as habilitações adquiridas exercem influência sobre os padrões de acumulação de poupanças e formação de capitais, além de alterarem as estruturas de pagamentos e salários e os totais de ganhos decorrentes do trabalho relativo ao montante do rendimento da propriedade. De forma simplificada, a educação é vista como um investimento que eleva a produtividade e os lucros dos trabalhadores, além de impulsionar 0 desenvolvimento econômico.

Formulado durante os anos de crescimento econômico, o conceito de Schultz (1967, apud LEMOS; DUBEUX; PINTO, 2009) forneceu uma explicação para as diferenças de desenvolvimento entre as nações capitalistas e rendimentos entre os indivíduos: os diferentes estoques de capital educacional justificariam essas diferenças, constituindo-se em receituário para a saída do subdesenvolvimento.

É nessas novas bases que a teoria do capital humano é apropriada pelo discurso que atualmente valoriza a qualificação profissional. Entendem os autores que a expressão "sociedade do conhecimento" atualiza a teoria do capital humano, delineando as exigências de qualificação e formação humana a partir dos conceitos de qualidade

\footnotetext{
2 Theodore Schultz (1902-1998) foi um economista americano que desenvolveu a teoria do capital humano entre o final da década de 1950 e o início dos anos 1960. Ganhou o prêmio Nobel de Economia em 1979.
} 
total, trabalho participativo em equipe, formação flexível, abstrata e polivalente. Mas, se é verdade que a produção informatizada e automatizada requer novas habilidades à força de trabalho, essas novas exigências não se dirigem ao universo da classe trabalhadora, mas a uma elite a qual estariam destinados os trabalhos estáveis e de qualidade (LEMOS; DUBEUX; PINTO, 2009, p. 372).

O conceito de sociedade do conhecimento, utilizado por Drucker (1999) e por Toffler (1998), apud Lemos, Dubeux e Pinto (2009), enfatiza a importância da força de trabalho, na medida em que esta consiga combinar polivalência, flexibilidade, iniciativa, capacidade de abstração e decisão, requisitos demandados pelas empresas que passam por processo de reconversão tecnológica. Mas a percepção dos autores é que, longe de representar uma evolução da teoria do capital humano ${ }^{3}$, o conceito de sociedade do conhecimento implica a intensificação da exploração da força de trabalho, que deve moldar integralmente sua qualificação às necessidades do setor produtivo.

Os autores afirmam que as premissas subjacentes à teoria do capital humano sustentam a valorização que a qualificação profissional vem recebendo no Brasil nos últimos anos, enfatizando a ideia de que o investimento em educação, ao aumentar a qualidade da força de trabalho, propicia ganhos de produtividade e aumento da criação de empregos de melhor qualidade, o que conduz ao crescimento econômico. A percepção de que a educação é um investimento e que a capacidade produtiva do trabalho é, em grande medida, um "meio de produção produzido"4, reforça a preocupação com a qualificação do trabalhador, entendida como potencializadora do crescimento econômico.

Entende-se que a educação aumentaria as chances individuais de acesso aos postos de trabalho, num cenário em que esses são cada vez mais escassos. O capital educacional acumulado pelo trabalhador asseguraria não só sua maior produtividade, mas também explicaria as diferenças individuais de oportunidades de inserção no mercado e de remuneração recebida.

\footnotetext{
${ }^{3}$ Concepção de que o trabalho humano, quando qualificado por meio da educação, seria um dos meios mais importantes a ampliação da produtividade econômica e das taxas de lucro do capital. Aplicada ao campo educacional, a ideia de capital humano gerou uma concepção tecnicista sobre o ensino e sobre a organização da educação, e sob essa visão, passou-se a disseminar a ideia de que a educação é o pressuposto do desenvolvimento econômico e do desenvolvimento do indivíduo, que, ao educar-se, estaria "valorizando" a si próprio, na mesma lógica em que se valoriza o capital. Para mais informações, vide Schultz, 1967. 4 "Nós produzimos a nós mesmos" (SCHULTZ, 1967, p. 25, apud LEMOS, DUBEUX; PINTO, 2009).
} 
Desafiados pela competição intensa por postos de trabalho, indivíduos procuram investir recursos crescentes na melhoria de sua formação profissional, na esperança de aumentar sua empregabilidade. Criticando a visão que incentiva essa atitude, Lemos, Dubeux e Pinto (2009) questionam se esse investimento efetivamente garante maior competitividade a essas pessoas, independentemente de sua origem social, ou se isso não passa de mais uma promessa que premia de forma desigual: é real para aqueles que combinam uma melhor qualificação profissional com uma origem socioeconômica melhor, ou ilusória, para aqueles que têm uma origem socioeconômica mais baixa, e cujo único diferencial seria uma formação de melhor qualidade.

Esta visão é corroborada por Kanamaru (2010, p. 3-4) quando afirma que:

Não obstante as inegáveis e fundamentais contribuições industriais à Humanidade, a possibilidade de simultaneidade histórica dos modos de produção e de vida hoje mais claros, permitem a reflexão pedagógica do lugar da criação pela mão humana principalmente na transição histórica da era industrial para a dos serviços, cujo avanço da informação torna gradativamente prescindível o operador humano também nos postos industriais. A crescente possibilidade de produção também não necessariamente permite o crescente acesso.

O autor propõe um papel mais criativo e humanizante para a educação, no sentido de que ela seja um veículo para a valorização do ser humano, e não apenas uma forma de inserção dos indivíduos num modelo econômico e político que é excludente pela sua própria constituição. Nesse sentido, Kanamaru (2010, p. 4) afirma que:

Nesse processo a pedagogia adquire relevância renovada no campo da criação, pois se os processos de produção e de consumo se desenvolvem na história sem necessariamente a participação majoritária e o atendimento às necessidades fundamentais humanas, aqueles à margem desse modelo de desenvolvimento poderiam revisar historicamente a sua (não) participação no trabalho de produção e o seu (não) acesso aos bens.

Relembrando Paulo Freire (1996, p. 10), é possível complementar que "a competência técnico-científica e o rigor de que o professor não deve abrir mão no desenvolvimento do seu trabalho, não são incompatíveis com a amorosidade necessária às relações educativas"

Compreende-se, pelo exposto neste capítulo, que a questão da mobilidade social e da participação da educação nesse processo é complexa e cercada de muitas críticas e questionamentos, que conduzem necessariamente 
ao questionamento do próprio modelo econômico vigente na sociedade e do papel da educação na sua manutenção ou mudança.

No Brasil, a educação profissional e tecnológica está essencialmente ligada a essa discussão, como se verá no próximo capítulo, que apresenta uma visão histórica dessa vertente educacional no País. 


\title{
3. EDUCAÇÃO PROFISSIONAL E TECNOLÓGICA NO BRASIL
}

Embora sejam cursos superiores, os cursos de formação de tecnólogos, no Brasil, são sempre associados à educação profissional. De acordo com Christophe (2005, p. 2):

\begin{abstract}
A expressão "educação profissional" é genérica e abrange vasta gama de processos educativos, de formação e de treinamento em instituições e modalidades variadas. Os termos educação profissional, ensino técnico, ensino profissionalizante, formação profissional, capacitação profissional e qualificação profissional costumam ser utilizados indistintamente na literatura e na prática. Referem-se tanto ao ensino ministrado nas instituições públicas e escolas regulares quanto a quaisquer processos de capacitação da força de trabalho, de jovens e adultos, ministrados por uma ampla variedade de cursos técnicos, de formação ou de treinamento, com natureza, duração e objetivos diferenciados. Estes cursos são oferecidos pelas instituições mais diversas, desde as organizações patronais que compõem o sistema S, até instituições privadas ou públicas que atuam em áreas de capacitação e desenvolvimento de recursos humanos, instituições comunitárias ou sindicais, departamentos de recursos humanos de empresas, organizações não governamentais etc.
\end{abstract}

Analisando a história da educação profissional no Brasil, Escott e Moraes (2012) afirmam que até o século XIX não existiam, no País, propostas sistemáticas de experiências de ensino, prevalecendo o que as autoras chamam de "educação propedêutica", e que era voltada para as elites, com o intuito de formar novos dirigentes. As autoras contam que data de 1809 a criação, pelo Príncipe Regente, futuro D. João VI, do Colégio das Fábricas, que pode ser considerado como o início da educação profissional no Brasil.

O processo de industrialização fez com que, no início do século $X X, 0$ poder público começasse a refletir a preocupação (já manifestada pelos empresários) com a preparação de operários para o exercício profissional. Kuenzer (2007) informa que somente a partir de 1909 o Estado brasileiro assume sua responsabilidade pela educação profissional, criando 19 escolas de artes e ofícios em diferentes unidades da federação, que foram as precursoras das escolas técnicas estaduais e federais.

Mas essas escolas surgiram ainda em um contexto de desenvolvimento industrial incipiente, e por isso, segundo Kuenzer (2007, p. 27), tiveram inicialmente "a finalidade moral de repressão: educar pelo trabalho, os órfãos, 
pobres, e desvalidos da sorte, retirando-os das ruas", caracterizando-se como a realização de políticas públicas moralizadoras, muito comuns na época, no mundo todo, e que pregavam a formação do caráter pelo trabalho.

Ao longo das décadas de 1930 e 1940, foram surgindo outras alternativas voltadas à formação dos trabalhadores. Até 1932, o curso primário vinha acompanhado das possibilidades de realização de curso rural e curso profissional com quatro anos de duração. Após esses quatro anos, o aluno poderia cursar alternativas de trajetória voltadas exclusivamente para a formação profissional (já no nível ginasial), como o chamado Curso Normal (formação de professores primários), o Técnico Agrícola ou o Técnico Comercial (CENTENÁRIO..., 2009).

Essas possibilidades de formação estavam de acordo com o período histórico, já que, na época, as atividades econômicas dos setores secundário e terciário eram ainda incipientes no país (que era então essencialmente agrícola, apenas começando a industrializar-se). Além disso, os níveis de ensino primário e ginasial (correspondentes aos atuais Ensino Fundamental I e II) não davam acesso ao ensino superior. Nesse período, a educação universitária era, mais do que nunca, reservada às elites, que após o ensino primário e secundário propedêutico, tinham a possibilidade de seguir sua trajetória de estudos no ensino superior, cujos cursos já eram então divididos em carreiras profissionais como Direito, Medicina e Engenharia (ESCOTT; MORAES, 2012).

Escott e Moraes (2012) enquadram essa divisão existente na educação brasileira dentro do modelo de administração taylorista-fordista ${ }^{5}$, caracterizado pela dicotomia entre as atividades de planejamento e supervisão de um lado, e de execução, de outro. De acordo com as autoras, essas duas funções do sistema produtivo caracterizavam as referidas trajetórias educacionais em

\footnotetext{
${ }^{5}$ Frederick Winslow Taylor (1856-1915), engenheiro mecânico norte-americano, é considerado o "pai da administração científica" e desenvolveu um conjunto de métodos para a produção industrial que ficou conhecido como taylorismo, pelo qual o funcionário deveria apenas exercer sua função/tarefa no menor tempo possível durante o processo produtivo, sem necessidade de conhecimento da forma como se chegava ao resultado final. Henry Ford (1863-1947), industrial norte-americano, fundador da fábrica de automóveis que leva seu nome, desenvolveu o sistema de organização do trabalho industrial denominado fordismo, cuja principal característica foi a introdução das linhas de montagem, nas quais cada operário ficava em um determinado local realizando uma tarefa específica, enquanto o automóvel (produto fabricado) se deslocava pelo interior da fábrica em uma esteira. Assim, o operário se especializava em apenas uma etapa do processo produtivo e repetia a mesma atividade durante toda a jornada de trabalho. Para mais informações, vide Maximiano, 2012.
} 
diferentes escolas: enquanto uma escola possibilitava uma formação intelectualizada, a outra, voltada aos trabalhadores, proporcionava uma formação profissional em instituições especializadas ou no próprio contexto de trabalho, ensinando principalmente habilidades operacionais, e esquecendo o desenvolvimento de habilidades psicofísicas e sociais.

Esse processo de industrialização e modernização das relações de produção parece ter acentuado a dualidade entre as formações intelectualizada e instrumental, e provocado o crescimento do número de escolas e cursos voltados ao atendimento dos diversos ramos profissionais.

A educação profissionalizante foi alvo de diversas iniciativas até o final dos anos 30, adquirindo uma importância crescente, conforme o País se industrializava, mas de forma lenta, já que também a industrialização da economia brasileira foi um processo lento, conforme Cunha (1986).

A Constituição Federal promulgada em 1937, sob o Estado Novo, dedicava atenção especial à educação profissional, mas, de acordo com Cunha (1986), ainda mantinha os vestígios assistencialistas da legislação anterior, embora propondo mudanças que não levavam em consideração a trajetória desse tipo de educação no País até aquele momento.

A chamada Reforma Capanema6, em 1942, mostra que o país efetivamente começa a dar importância à educação, definindo leis específicas para a formação profissional em cada ramo da Economia, assim como para a formação de professores em nível médio (curso Normal). Nessa nova estruturação do ensino foram criados os chamados "cursos médios de segundo ciclo", que ficaram conhecidos como Científico e Clássico, com duração de três anos, com o objetivo de preparar os estudantes para o ingresso no ensino superior. A educação profissionalizante, realizada na parte final do ensino secundário, era constituída pelos cursos Normal, Industrial Técnico, Comercial Técnico e Agrotécnico, com o mesmo nível e duração dos demais, mas que não habilitavam para o ingresso no ensino superior. Nesse contexto, foram criados os exames de adaptação que permitiriam, aos estudantes dos cursos profissionalizantes, participar dos exames para ingresso no ensino superior (ESCOTT; MORAES, 2012).

${ }^{6}$ Assim denominada por causa de Gustavo Capanema Filho (1900-1985), ministro da Educação e Saúde de 1934 a 1945. Para mais informações, vide Schwartzman, Bomeny e Costa, 1984. 
A Constituição brasileira de 1937 foi a primeira a tratar especificamente de ensino técnico, profissional e industrial, estabelecendo em seu artigo 129:

\begin{abstract}
O ensino pré-vocacional e profissional destinado às classes menos favorecidas é, em matéria de educação, o primeiro dever do Estado. Cumpre-lhe dar execução a esse dever, fundando institutos de ensino profissional e subsidiando os de iniciativa dos Estados, dos Municípios e dos indivíduos ou associações particulares e profissionais. É dever das indústrias e dos sindicatos econômicos criar, na esfera de sua especialidade, escolas de aprendizes, destinadas aos filhos de seus operários ou de seus associados. A lei regulará o cumprimento desse dever e os poderes que caberão ao Estado sobre essas escolas, bem como os auxílios, facilidades e subsídios a lhes serem concedidos pelo poder público (BRASIL, 1937).
\end{abstract}

É importante notar, a partir do texto da própria Constituição Federal, a expressão daquilo que já parecia ser uma compreensão tácita das instituições e da própria sociedade: a educação profissionalizante é destinada às classes menos favorecidas. No mesmo trecho, a Constituição consolida a sugestão de que o próprio setor industrial, por meio de sindicatos e associações, deve promover a educação para o trabalho dos filhos de seus operários e associados, oferecendo a eles a possibilidade de continuarem na profissão de seus pais, perpetuando assim aquela estratificação social discutida no capítulo 2 .

Escott e Moraes (2012) lembram que a primeira LDB (Lei de Diretrizes e Bases da Educação Brasileira) foi promulgada só em 1961 (Lei no 4.024/1961), e trouxe mudanças significativas para a educação profissionalizante, mas mantendo a existência de duas modalidades distintas de ensino.

Em 1971, sob o governo militar, ocorre outra grande reforma da educação básica, promovida pela Lei $n^{\circ}$ 5.692/71, que foi chamada de Lei da Reforma de Ensino de $1^{\circ}$ e $2^{\circ}$ graus e, segundo as autoras, constituiu-se em uma tentativa de estruturar a educação de nível médio como profissionalizante para todos, eliminando assim a divisão entre as áreas do conhecimento que era representada pelos três tipos de cursos: Científico, Clássico e Normal. Essas mudanças concentraram-se nos cursos primário, ginasial e colegial, que passaram a chamar-se, respectivamente, primeiro grau (englobando o primário e o ginasial) e segundo grau.

Escott e Moraes (2012, p. 1496) pontuam que:

Destaca-se como aspecto relevante e, ao mesmo tempo, polêmico, o caráter de profissionalização obrigatória do ensino de $2^{\circ}$ grau, imposto por um governo autoritário com o discurso de atendimento à crescente 
demanda das classes populares por acesso a níveis mais elevados de escolarização, acarretando, da mesma forma, uma forte pressão pelo aumento das vagas no ensino superior. Associado a esses fatos, reside o interesse do governo militar no desenvolvimento de uma nova fase de industrialização subalterna, conhecido historicamente como 0 milagre brasileiro. Tal projeto demandava mão-de-obra qualificada, com técnicos de nível médio, para atender a tal crescimento, possibilitada pela formação técnica profissionalizante em nível de $2^{\circ}$ grau, que garantiria a inserção no mercado de trabalho, devido ao crescente desenvolvimento industrial, marcado pela intensificação da internacionalização do capital.

Mas essa mudança não surtiu os efeitos desejados. Vários autores apontam que as escolas públicas tiveram grandes dificuldades técnicas para oferecer uma educação efetivamente profissionalizante, por falta de investimento em equipamentos e materiais necessários. Além disso, enfrentavam a falta de professores qualificados para a tarefa e o desinteresse da própria sociedade por esse tipo de formação (já que o "milagre econômico" não aconteceu nos níveis esperados), o que foi enfraquecendo a reforma, que acabou definitivamente sepultada por outra lei, a 7.046/1982, que restabeleceu a modalidade de educação geral para o segundo grau.

Para Kuenzer (2007), essa legislação apenas normatizou um arranjo conservador que já vinha ocorrendo, na prática, nas escolas. Retornou-se ao antigo modelo, com uma diferença: o ensino técnico público (concentrado agora em poucos Centros Federais de Educação espalhados pelo país) também oferecia uma formação voltada para preparar seus alunos para o ingresso no ensino superior.

Esse período - segunda metade da década de 1980 e toda a década de 1990 - é marcado por uma certa estagnação do ensino técnico. Embora ele continue existindo em algumas escolas técnicas públicas (federais e estaduais) e nas redes do SENAI e do SENAC, o ensino superior ganha destaque. Cresce o número de estudantes que chegam ao final do Ensino Médio, criando uma demanda inédita no país pelos cursos universitários. Intensifica-se o processo de criação de novas instituições privadas e novos cursos de nível superior.

Como consequência direta das diretrizes para a educação contidas na nova Constituição Federal, promulgada em 1988, em 20 de dezembro de 1996 foi sancionada a Lei 9394, considerada como a "segunda LDB", ou "nova LDB", como passou a ser chamada. 
A nova LDB dispõe sobre a Educação Profissional num capítulo separado da Educação Básica, superando enfoques de assistencialismo e de preconceito social contido nas primeiras legislações de educação profissional do país. Além disso, define o sistema de certificação profissional que permite o reconhecimento das competências adquiridas fora do sistema escolar. O Decreto 2.208/1997 regulamenta a educação profissional e cria o Programa de Expansão da Educação Profissional - PROEP. Em meio a essas complexas e polêmicas transformações da educação profissional no país, retoma-se em 1999 o processo de transformação das Escolas Técnicas Federais em Centros Federais de Educação Tecnológica, iniciado em 1978 (CENTENÁRIO..., 2009).

Ademais das mudanças no sistema público de educação profissionalizante, as novas leis e programas contribuem para renovar 0 interesse da própria sociedade e, principalmente, dos jovens pela formação técnica, agora não mais equivalente ao Ensino Médio, mas oferecida como modalidade complementar, de forma concomitante ou subsequente ao EM (ou pós-médio, como chegou a ser conhecido por um breve período).

\subsection{A educação tecnológica}

Ao lado dessas mudanças no ensino técnico, o ensino superior brasileiro também passa por grandes mudanças em função da nova LDB (Lei 9394/96). A característica profissionalizante, que sempre esteve presente na educação superior brasileira, e que já havia sido enfatizada pela chamada Lei da Reforma Universitária (Lei 5540/68), implementada pelo governo militar em 1968, tornase mais enfática a partir dessas mudanças.

Um dos pontos centrais dessa ênfase na formação profissional de nível superior é a recriação dos cursos superiores de tecnologia. De acordo com Macedo (1995, p. 9):

A formação do tecnólogo surgiu na Europa, no século passado, na Alemanha e na Suíça, na área de engenharia, como parte do ensino das Escolas Politécnicas. A ideia foi trazida ao país, em particular para São Paulo, por Antonio Francisco de Paula Souza (1843-1917), que justamente havia estudado naqueles dois países precursores. Assim, foi criado em 11 de maio de 1892 o Instituto Politécnico de São Paulo, com diversos cursos especiais. 
O Instituto Politécnico de São Paulo tornou-se, mais tarde, a Escola Politécnica da USP, dedicada à oferta de cursos de bacharelado em engenharia. Mas, para Macedo, A. R. (1995), essa foi a semente da criação dos cursos de formação de tecnólogos, que surgiram, no âmbito do sistema federal de ensino e do setor privado e público, em São Paulo, no final dos anos 60 e início dos anos 70. O primeiro curso superior de tecnologia a funcionar no Brasil, em 19697, foi o de Construção Civil, nas modalidades Edifícios, Obras Hidráulicas e Pavimentação, da FATEC, em São Paulo, reconhecido pelo MEC em 1973.

Os cursos de formação de tecnólogos passaram por uma fase de crescimento durante os anos 70, mas em 1979, o MEC mudou sua política de estímulo à criação de cursos de formação de tecnólogos nas instituições públicas federais, e a partir dos anos 80 muitos desses cursos foram extintos no setor público, restando apenas a oferta de instituições privadas.

Em 1988, 53 instituições de ensino ofereciam cursos superiores de tecnologia (nova denominação a partir de 1980), e cerca de 60\% eram privadas. Em 1995, o país já contava com 250 cursos superiores de tecnologia, na sua maioria ofertados pelo setor privado e mais da metade na área da computação. Em 1998, esses cursos representavam 5\% do total de matrículas da graduação. Em 2000, o Brasil dispunha de 554 cursos superiores de tecnologia, com 104 mil alunos (70\% até 24 anos, $24 \%$ de 25 a 34 anos, $6 \%$ com 35 anos ou mais). Destes, $32 \%$ eram de Processamento de Dados; $14 \%$, de Turismo; $11 \%$, de Secretariado Executivo; 7\%, de Análise de Sistemas; 5\%, de Zootecnia e 31\% de outras modalidades. Na época, existiam 70 modalidades diferentes de cursos superiores de tecnologia sendo ofertadas em todas as áreas profissionais (CENTENÁRIO..., 2009).

A partir de um estudo da legislação sobre educação profissional e, mais especificamente, sobre educação tecnológica, realizado em 2005, a autora define que "educação tecnológica refere-se a um nível da educação profissional, correspondente aos cursos de nível superior, destinados aos egressos do ensino médio e técnico, e regulamentados por dispositivos próprios" (CHRISTOPHE, 2005, p. 3).

\footnotetext{
${ }^{7}$ Ano da criação, na capital paulista, do Centro Estadual de Educação Tecnológica Paula Souza (CEETEPS), que engloba atualmente as Escolas Técnicas (ETECs) e as Faculdades de Tecnologia (FATECs) do Estado de São Paulo (MOTOYAMA, 1995).
} 
Desde 1998, os cursos superiores de tecnologia têm sido os que mais crescem em número de matrículas no Brasil. O número de cursos tecnológicos passou de 258 em 1998 para 4.355 em 2008, aumento de mais de $1.200 \%$ em uma década, segundo dados do INEP - Instituto Nacional de Estudos e Pesquisas Educacionais Anísio Teixeira. No mesmo período, a totalidade dos cursos de graduação teve um crescimento (bacharelado e licenciatura) bem inferior, em torno de $250 \%$. O número de matriculados nos cursos tecnológicos também cresceu no mesmo período, de 63.046 para 287.727 , ou seja, $426 \%$ (CENSO..., 2009).

No ano de 2013, 2.391 instituições participaram do Censo da Educação Superior, pesquisa promovida anualmente pelo INEP. De acordo com esses dados, percebe-se uma pequena redução nas instituições das categorias administrativas municipal (de 85 , em 2012, para 76 , em 2013) e privada (de 2.100, em 2010, para 2.081, em 2011, e de 2.112, em 2012, para 2.090, em 2013). Pode-se observar, em todo o período, a predominância da categoria privada, sendo que em 2013 ela representou $87,4 \%$ do total das IES. O restante, $12,6 \%$, refere-se às instituições públicas. Essa proporção se manteve estável nos quatro anos analisados: para cada instituição pública, existem aproximadamente sete instituições privadas. A categoria estadual foi a que apresentou maior crescimento (10,2\%) nos anos de 2010 a 2013. Apesar do crescimento do número de instituições de ensino superior (IES) ao longo da última década (71\% de crescimento de 2002 a 2010), é perceptível a tendência de estabilização do número de IES, conforme mostra a Tabela 1 (CENSO..., 2013).

Tabela 1 - Evolução do número de IES no Brasil - 2010-2013

\begin{tabular}{|c|c|c|c|c|c|}
\hline \multirow{2}{*}{ Ano } & \multirow{2}{*}{ Total } & \multicolumn{5}{|c|}{ Categoria Administrativa } \\
\cline { 3 - 6 } & & Federal & Estadual & Municipal & Privada \\
\hline 2010 & 2.378 & 99 & 108 & 71 & 2.100 \\
\hline 2011 & 2.365 & 103 & 110 & 71 & 2.081 \\
\hline 2012 & 2.416 & 103 & 116 & 85 & 2.112 \\
\hline 2013 & 2.391 & 106 & 119 & 76 & 2.090 \\
\hline
\end{tabular}

Fonte: Censo..., 2013, p. 15.

Em relação ao grau acadêmico (bacharelado, licenciatura e tecnológico), os resultados do Censo 2013 mostram que, entre 2010 e 2013, o grau 
bacharelado superou os demais, em todos os anos, representando $55,9 \%$ do total em 2013. Verifica-se que tanto o bacharelado quanto o tecnológico ampliaram o número de cursos ano a ano. Já a licenciatura apresentou um comportamento instável, sendo que em 2011 e em 2013 houve redução do número desses cursos em relação ao ano anterior, de $0,1 \%$ e $3,3 \%$, respectivamente, apresentando crescimento de 3,6\% em 2012.

Embora o bacharelado possua maior número de cursos, o tecnológico alcançou maior percentual de crescimento $(24,5 \%)$ de 2010 a 2013, enquanto $o$ bacharelado cresceu somente 7,9\%, conforme mostra a Tabela 2. (CENSO..., 2013).

Tabela 2 - Evolução do número de cursos de graduação - 2010-2013

\begin{tabular}{|c|c|c|c|c|}
\hline \multirow{2}{*}{ Ano } & Total Geral & Bacharelado & Licenciatura & Tecnológico \\
\hline 2010 & 29.507 & 16.586 & 7.922 & 4.999 \\
\hline 2011 & 30.420 & 17.031 & 7.911 & 5.478 \\
\hline 2012 & 31.866 & 17.703 & 8.194 & 5.969 \\
\hline 2013 & 32.049 & 17.905 & 7.920 & 6.224 \\
\hline
\end{tabular}

Fonte: Censo..., 2013, p. 19.

Assim, compreende-se que a graduação tecnológica vem se tornando, cada vez mais, uma alternativa de formação para os egressos do Ensino Médio que buscam uma continuidade de sua formação mas, eventualmente, não podem ou não querem investir todo o tempo de estudo demandado pelos cursos de bacharelado (quatro anos ou mais). De acordo com o próprio INEP, o fato de os cursos tecnológicos possibilitarem uma formação mais rápida e integrativa do tipo "educação, trabalho, ciência e tecnologia" pode ter contribuído para aumentar a sua demanda (CENSO..., 2013).

Dentro das grandes áreas nas quais estão divididos os cursos de tecnologia, de acordo com o Catálogo Nacional de Cursos de Tecnologia ${ }^{8}$, a moda está contemplada na área de Produção Cultural e Design, com o curso de

\footnotetext{
${ }^{8}$ Disponível em: http://eafspb.gov.br/cursos/superior/arquivos/catalogo_superior.pdf.
} 
Tecnologia em Design de Moda, e na área de Produção Industrial, com os cursos de Tecnologia em Produção de Vestuário e Tecnologia em Produção Têxtil.

\subsection{O papel do SENAI no contexto da educação profissional brasileira}

O Serviço Nacional de Aprendizagem Industrial - SENAI foi fundado em 1942, e foi seguido, quatro anos depois, em 1946, pela criação do Serviço Nacional de Aprendizagem Comercial - SENAC. Ambos são sistemas privados de educação profissional voltados, respectivamente, à formação de profissionais para a indústria e para o comércio, como iniciativas dos setores empresariais, incentivados pelas disposições constitucionais e também cientes da necessidade de investimento em sua mão de obra futura. Posteriormente, foram criados também o Serviço Social da Indústria - SESI e o Serviço Social do Comércio - SESC, ambos em 1946. O conjunto da quatro instituições passou a ser conhecido depois pelo nome de Sistema S.

O SENAI foi criado em janeiro de 1942, por decreto-lei assinado pelo presidente Getúlio Vargas, e que estabelecia que a nova instituição teria a missão de formar profissionais para a indústria nacional, e seria mantida com recursos dos empresários e administrada pela Confederação Nacional da Indústria (CNI). Para implantar um sistema nacional de educação profissional, os empresários Euvaldo Lodi, então presidente da CNI, e Roberto Simonsen, que, na época, presidia a Federação das Indústrias do Estado de São Paulo (FIESP), inspiraram-se na experiência bem-sucedida do Centro Ferroviário de Ensino e Seleção Profissional.

Ao longo das décadas seguintes, o SENAI tornou-se referência na área de formação profissional, servindo de modelo para a criação de instituições similares na Venezuela, Chile, Argentina e Peru. Além da educação profissional em diversos níveis, a instituição também oferece assistência às empresas e desenvolve atividades de pesquisa e desenvolvimento tecnológico. Com o apoio técnico e financeiro de instituições da Alemanha, Canadá, Japão, França, Itália e Estados Unidos, o SENAI oferece educação profissional de acordo com as necessidades da indústria, consolidando a metodologia SENAI de educação profissional. Investe também na ampliação da oferta de cursos de qualificação 
profissional e dos cursos técnicos de nível médio, por meio da educação à distância.

Atualmente, o SENAI São Paulo dispõe de 165 unidades, sendo 91 escolas fixas e 74 unidades móveis. Em 2015, o total de matrículas nessas unidades (Departamento Regional São Paulo) ficou assim: Aprendizagem Industrial, 33.426; Curso Técnico, 29.649; Superior - Formação de Tecnólogo, 3.618; Superior - Pós-Graduação Lato Sensu, 1.396; Superior - Extensão, 54; Ensino à Distância, 290.872; Iniciação Profissional, 286.102; Aperfeiçoamento Profissional, 4.770; Formação Inicial e Continuada, 409.523; Iniciação Profissional, 47.147; Qualificação Profissional, 112.772; Aperfeiçoamento Profissional, 241.111; Especialização Profissional, 8.493; Educação de Jovens e Adultos, 318; Educação Básica, 24, num total de 768.880 matrículas diretas e 231.779 matrículas indiretas.

Os Cursos Superiores de Tecnologia estão distribuídos em 16 faculdades, integradas às unidades do SENAI em todo o Estado de São Paulo. São 14 cursos de Graduação Tecnológica, nas áreas de Manutenção Industrial, Alimentos, Automação Industrial, Eletrônica Industrial, Fabricação Mecânica, Mecatrônica Industrial, Polímeros, Processos Ambientais, Processos Metalúrgicos, Produção Gráfica, Produção de Vestuário, Sistemas Automotivos, Mecânica de Precisão e Instrumentação Industrial. Além disso, o SENAI-SP oferece também 34 cursos de Pós-Graduação Lato Sensu (Especialização).

O curso de Tecnologia em Produção de Vestuário é oferecido na Faculdade de Tecnologia SENAI Antoine Skaf, localizada no bairro do Brás, em São Paulo - SP. A alocação do curso nessa unidade, especificamente, leva em consideração a vocação do bairro que, juntamente, com o Bom Retiro, tem sido, historicamente, o polo de concentração da indústria têxtil e de vestuário na capital paulista. 


\section{EDUCAÇÃO, HABILIDADES E COMPETÊNCIAS}

As mudanças na educação brasileira, discutidas no capítulo anterior, ocorrem ao mesmo tempo que, no mundo todo, a educação começa a sofrer mudanças motivadas pela revolução tecnológica, que se torna mais acelerada a cada ano. De 5 a 9 de março de 1990 a ONU - Organização das Nações Unidas promove, por meio de seu órgão para a educação e a cultura, a UNESCO, sua primeira conferência mundial sobre educação, com o tema "Educação para Todos". Realizada em Jomtien, na Tailândia, a conferência resultou numa série ações e documentos que tiveram por objetivo oferecer subsídios aos paísesmembros para que efetuassem mudanças em seus sistemas educacionais, visando à formação das novas gerações para o século XXI.

Um desses documentos é o relatório da Comissão Internacional sobre Educação para o Século XXI, presidida pelo economista e político francês Jacques Delors. Com o título de "Educação, um tesouro a descobrir", foi publicado em forma de livro, a partir de 1996, em todos os países-membros da ONU. No Brasil, a primeira edição é de 1997. No primeiro capítulo desse livro, Delors propõe o que ficou conhecido como "os quatro pilares para a educação do futuro", que são: aprender a conhecer, aprender a fazer, aprender a viver junto e aprender a ser.

Silva e Cunha (2002) explicam que aprender a viver junto é considerado uns dos pilares mais importantes do processo educativo desses novos tempos. Ressalta a interdependência do mundo moderno e a importância das relações. Tudo está interligado e tudo que acontece afetará a todos de uma forma ou de outra.

Já o aprender a conhecer é um pilar que tem como cenário o prazer de compreender, de conhecer e de descobrir. Aprender para conhecer supõe aprender para aprender, exercitando a atenção, a memória e o pensamento.

Aprender a fazer significa que a educação não pode aceitar a imposição de opção entre a teoria e a técnica, o saber e o fazer. A educação para o novo século tem a obrigação de associar a técnica com a aplicação de conhecimentos teóricos. 
Finalmente, aprender a ser é um pilar que já havia aparecido em outro documento da UNESCO, o Relatório Edgard Faure, na década de 1970, significando, resumidamente, que o mundo atual exige de cada pessoa uma grande capacidade de autonomia e uma postura ética, porque considera-se que os atos e as responsabilidades pessoais interferem no destino coletivo.

Ao mesmo tempo que organismos internacionais como a ONU procuravam discutir a educação em âmbito mundial, o mundo enfrentava outros desafios, sendo o principal deles a chamada "revolução informática", que provocou mudanças profundas e muito rápidas na economia e na produção. Trevisan (2010) destaca que essa nova automação passou a exigir um outro tipo de trabalhador, diferente daquele demandado pela organização fordista do trabalho, vigente nas empresas brasileiras até a década de 1970.

O autor considera que, após um primeiro momento de grandes discussões sobre o impacto das novas tecnologias na macroestrutura econômica e produtiva, os estudiosos do tema voltaram-se para questão da formação do trabalhador, uma vez que a nova realidade de trabalho passava a demandar um trabalhador com habilidades para lidar com a tecnologia (TREVISAN, 2010).

De acordo com Trevisan (2010, p. 196):

(...) Tais habilidades não permitiam apenas o convívio do trabalhador com as máquinas da geração tecnológica existentes na empresa que oferecia o treinamento. Elas se transformavam em patrimônio cognitivo do trabalhador treinado, gerando um tipo diferente de "valor-trabalho". Esse "patrimônio" acumulado gerava o potencial de empregabilidade.

O autor menciona que o termo "empregabilidade", assim como os termos "habilidades" e "competências" foram se tornando cada vez mais conhecidos e usados com frequência na discussão da formação desse "novo trabalhador" para essa "nova economia", e acabou atingindo - e afetando profundamente - as discussões educacionais.

Trevisan (2010, p. 196) define que:

Empregabilidade é o conjunto de habilidades profissionais que diferencia o trabalhador e o torna "empregável" pelo interesse que desperta no empregador, devido a seu conhecimento acumulado. Essa empregabilidade, porém, precisa estar compatível com o conjunto de expectativas da empresa.

É no contexto dessas transformações que várias reformas educacionais são realizadas, não só no Brasil, como em outros países. No Brasil, é aprovada 
e promulgada a Lei de Diretrizes e Bases da Educação (Lei 9.394, de 20 de dezembro de 1996), que logo passou a ser chamada de "nova LDB", que ensejou grandes mudanças na educação brasileira, em todos os níveis. Naturalmente, essas mudanças não ocorreram apenas em função da nova legislação, e nem imediatamente após a sua entrada em vigor.

Para Frigotto (2000), o Brasil dos anos 90 registra uma alteração profunda de seu sistema educacional como um todo. Essas mudanças ajustam a educação nos âmbitos organizacional, de financiamento e de projeto políticopedagógico, mas o autor não vê com bons olhos algumas dessas mudanças, que ele considera como "adequações a um ideário de reformas neoliberais". Em sua opinião, essas reformas acabam por ampliar o processo de exclusão social (de resto, já bastante presente na educação brasileira, ao longo de sua história), fortalecendo um "ideário utilitarista e individualista".

Segundo o autor, é dentro desse ideário que, nas políticas públicas para a educação profissional, ressurgem a ideologia das competências, das habilidades e as noções ideológicas de empregabilidade e laboralidade. Ele critica o fato de que a noção de "empregabilidade", no seu entender, parte do princípio de que os trabalhadores desempregados encontram-se nessa situação porque não se adaptam às novas exigências de qualificação requeridas pelo novo paradigma produtivo. Dentro dessa noção, responsabiliza-se individualmente o trabalhador pelo seu desemprego (FRIGOTTO, 2000).

Apesar das críticas, no entanto, esses conceitos foram se tornando cada vez mais conhecidos e empregados na discussão da nova realidade laboral e educacional do século XXI.

Discutindo a noção de competência, Perrenoud (2000) a descreve como uma "capacidade de mobilizar diversos recursos cognitivos para enfrentar um tipo de situação" (p. 15), afirmando que, ao descrever uma competência, é preciso evocar três elementos complementares: os tipos de situações que podem ser mais ou menos "dominadas" por essa competência; os recursos que essa competência mobiliza no indivíduo, como os conhecimentos teóricos ou metodológicos, as atitudes, o saber-fazer e as competências mais específicas, como os esquemas motores, de percepção, de avaliação, de antecipação e de decisão; finalmente, a natureza dos esquemas de pensamento que permitem a 
solicitação e mobilização organizada dos recursos necessários a uma situação complexa e em tempo real.

Nesse sentido, o autor evoca uma similaridade entre as concepções educacionais que caracterizam 0 início do século XXI e aquelas que caracterizaram o movimento conhecido como Escola Nova, que marcou o início do século XX e foi, no dizer de Gadotti (2002, p. 142), "o mais vigoroso movimento de renovação da educação depois da criação da escola pública burguesa".

De acordo com Gadotti (2002, p. 143):

O educador norte-americano John Dewey (1859-1952) foi o primeiro a
formular o novo ideal pedagógico, afirmando que o ensino devia dar-
se pela ação (learning by doing) e não pela instrução (...). Para ele, a
educação continuamente reconstruía a experiência concreta, ativa,
produtiva, de cada um. A educação preconizada por Dewey era
essencialmente pragmática, instrumentalista. Buscava a convivência
democrática sem, porém, pôr em questão a sociedade de classes.

A educação pelo trabalho, defendida por Dewey, afirmava que o fazer era sempre a melhor forma de aprendizagem porque, segundo ele, diante de qualquer problema, o ato de pensar se desenvolve numa escala que engloba cinco estágios: uma necessidade sentida; a análise das dificuldades relacionadas a essa necessidade; a busca de alternativas de solução do problema; a experimentação de várias soluções; a ação como prova final para a solução proposta, ressalvando que essa solução deve ser desenvolvida e verificada de maneira científica (GADOTTI, 2002).

A educação pelo trabalho foi também a bandeira defendida pelo educador francês Célestin Freinet (1896-1966), que afirmava a existência de uma dependência entre a escola e o meio social, de forma a concluir que não existe uma educação ideal, mas apenas uma educação de classes. A partir disso, sua opção foi pela classe trabalhadora, criticando a escola tradicional e propondo uma forma de educar na qual o trabalho ocupava posição central, como metodologia (GADOTTI, 2002).

Kanamaru (2014, p. 773) aponta que:

Antes de alcançar esse desenvolvimento teórico-metodológico, em seus primeiros anos Freinet analisou criticamente os fundamentos e a prática da pedagogia escolástica, revendo sua própria experiência na escola dominante à época, a qual considerava traumática e domesticadora em função da separação, de caráter intelectualista e 
dogmática, entre conteúdo e forma didática de um lado e, de outro, das necessidades reais de educandos. Assim, tornou-se crítico acerbo e pesquisador pedagógico para a construção de uma pedagogia efetivamente científica. Observava que a pedagogia escolástica no aspecto geral apenas sujeitava educandos à passividade, à repetição e à subordinação, em frontal contradição quanto à autonomia do educando, fundamental para o rigor da vida no campo e para a vida.

Ainda de acordo com Kanamaru (2014, p. 777):

(...) Freinet não operava didática e pedagogicamente a partir de ideias puras, mas, consciente das relações materiais concretas de produção, sistematizou o uso e a apropriação coletiva das técnicas em torno da imprensa escolar e de outras novas mídias daquele contexto. Essa medida, além de oferecer as condições objetivas concretas para a produção dessas relações didáticas, gerava principalmente as condições reais de autonomia, livre trabalho e livre expressão de educandos e também de educadores. A pedagogia de Freinet, nesse aspecto, proporcionou a organização da escola popular como um centro de comunicação por excelência, mas baseado no trabalho cooperado real. Nesse aspecto, opunha-se à escola nova, cujas considerações gerais já eram existentes mais amplamente na teoria liberal da escola-canteiro ou escola-laboratório, de John Dewey.

No dizer de Macedo, L. (2005a), um dos significados de competência é sua natureza "atributiva", ou seja, trata-se de algo pessoal ou produzido por um grupo, mas que ao mesmo tempo supõe reconhecimento, avaliação ou atribuição. Estes só podem ser atribuídos por algo externo à pessoa ou às pessoas que, naquela circunstância, demonstraram uma competência reconhecida ou legitimada.

Assim, segundo o autor, a educação profissional, pela sua especificidade de formar para o trabalho, identifica-se com o enfoque de competências. No desenvolvimento curricular, as ações de planejamento de ensino e avaliação da aprendizagem pressupõem situações de aprendizagem que promovam a mobilização de conhecimentos, habilidades e atitudes, requerendo integração e articulação de conteúdos formativos, tendo como foco a resolução de problemas não só rotineiros, mas também inusitados, no campo de atuação profissional (MACEDO, L., 2005a).

Ao mesmo tempo, as novas tecnologias da informação e a vocação do novo século $X X I$, como o século do conhecimento, passam a exigir uma melhor formação geral e cultural, além da mera visão da especialização em áreas afins, o que só vem aumentar o grande desafio do processo democrático, garantidor do direito à educação. É importante lembrar que uma das tarefas mais 
importantes no processo educacional, hoje, é ensinar como chegar à informação. Parte da consciência de que é impossível estudar tudo, de que o conhecimento não cessa de progredir e se acumular. Então o mais importante é saber conhecer os meios para se chegar até ele (SILVA; CUNHA, 2002).

As competências representam potenciais desenvolvidos sempre em contextos de relações disciplinares em determinado âmbito de atuação. As formas de realização das competências foram chamadas de habilidade, um feixe de habilidades caracteriza-se a competência e as disciplinas são meios para desenvolver as habilidades. Para Macedo, L. (2005a), uma competência está sempre associada a uma mobilização de saberes, à capacidade de recorrer aos conhecimentos para a realização de uma atividade.

Desta forma, as competências constituem padrões de articulação do conhecimento a serviço da inteligência. A escola organiza-se basicamente em termos de conhecimentos, apresentado sob a forma de conteúdos disciplinares. Porém, conhecer é entender o significado, e o significado é sempre construído pelas pessoas.

$\mathrm{Na}$ escola, os currículos constituem um mapeamento do conhecimento considerado relevante para ser ensinado aos alunos, visando torná-los pessoas competentes. Nesse sentido, a busca da integração entre as disciplinas passa a significar o deslocamento do foco das atenções dos conteúdos disciplinares para o projeto das pessoas, e a contextualização favorece a construção dos significados, constituindo-se uma estratégia fundamental na mobilização do conhecimento, pois, segundo Macedo, L. (2005a), não existe uma competência sem a referência a um contexto no qual ela se materializa. As competências representam potenciais desenvolvidos sempre em contextos de relações disciplinares significativas, prefigurando ações a serem desenvolvidas em determinado âmbito de atuação.

Ainda de acordo com Macedo, L. (2005a), já há algum tempo as transformações no quadro de ocupações no mundo do trabalho ocorrem em um ritmo acelerado; já não se aprende mais a manejar certo tipo de máquina, mas sim a entender novos manuais. Para o autor, parece cada vez mais claro que tanto a formação escolar quanto a formação profissional justificam-se apenas se concentrarem no desenvolvimento das competências pessoais. 
Desta forma, compreende-se que a escola deve prover as pessoas de competências básicas, tais como: capacidade de expressão, compreensão, interpretação, capacidade de tomar decisões, trabalhar em equipe e, sobretudo a capacidade de resolver problemas. Mas essas competências não se desenvolvem só com a utilização de conteúdos e equipamentos; por isso, mesmo a formação profissional já atingiu um patamar de compreensão de que é preciso oferecer uma formação que possibilite ao aluno o desenvolvimento pleno de seu potencial e capacidades pessoais.

Duarte (2001), no entanto, critica fortemente essa corrente educacional. Para ele, a chamada "educação por competências" ou "aprender a aprender" contêm ilusões que podem ser perigosas para os indivíduos e para a sociedade como um todo, porque trazem embutidas algumas ideias que ele classifica como ilusões.

O autor aponta e questiona quatro "posicionamentos valorativos" que, a seu ver, estão subentendidos no conceito de "aprender a aprender": 1) aquilo que o indivíduo aprende por si mesmo é superior, em termos educativos e sociais, àquilo que ele aprende através da transmissão por outras pessoas; 2) o método de construção do conhecimento é mais importante do que o conhecimento já produzido socialmente; 3) a atividade do aluno, para ser verdadeiramente educativa, deve ser impulsionada e dirigida pelos interesses e necessidades da própria criança; 4) a educação deve preparar os indivíduos para acompanharem a sociedade em acelerado processo de mudança, ou seja, enquanto a educação tradicional seria resultante de sociedades estáticas, nas quais a transmissão dos conhecimentos e tradições produzidos pelas gerações passadas era suficiente para assegurar a formação das novas gerações, a nova educação deve pautar-se no fato de que vivemos em uma sociedade dinâmica, na qual as transformações em ritmo acelerado tornam os conhecimentos cada vez mais provisórios, pois um conhecimento que hoje é tido como verdadeiro pode ser superado em poucos anos.

De acordo com Duarte (2001, p. 37):

A relação entre o terceiro posicionamento valorativo e os dois primeiros consiste em ressaltar que, além de o aluno buscar por si mesmo o conhecimento e, nesse processo, construir seu método de conhecer, é preciso também que o motor desse processo seja uma necessidade inerente à própria atividade do aluno, ou seja, é preciso que a 
educação esteja inserida de maneira funcional na atividade da criança, na linha da concepção de educação funcional de Claparède.

Silva e Cunha (2002) reconhecem que, no decorrer das últimas décadas, observou-se que a questão da qualificação profissional - entendida como requisito da empregabilidade - vem se constituindo como importante desafio a ser enfrentado pelos profissionais que pretendem se inserir no mercado de trabalho. O debate acerca das transformações em curso no mundo do trabalho tem sido pautado pela ênfase nos novos perfis profissionais que passam a ser requeridos nesse novo contexto.

Os autores enfatizam que, nesse contexto, o papel econômico da educação é revalorizado, ainda que em bases diferentes do ocorrido na década de 1960, quando era associada ao crescimento econômico e à integração social dos indivíduos. A partir da crise do capitalismo avançado, a educação passa a desempenhar novo papel, sendo chamada não mais a promover o desenvolvimento econômico (conforme preconizava a teoria do capital humano), mas a aumentar as chances individuais de inserção no mercado de trabalho ou, em outros termos, a aumentar a empregabilidade dos indivíduos, num cenário em que o desemprego tecnológico parece que veio para ficar.

Garcia e Lima Filho (2004, p. 28) também tecem críticas ao modelo de formação voltado exclusivamente para o mercado, mas defendem a educação técnica e tecnológica já a partir do Ensino Médio:

Considerando a possibilidade e as evidências da realidade atual de que grande parte dos dois milhões de egressos anuais do Ensino Médio não ingressará no ensino superior (...), para estes adolescentes e jovens adultos, o ingresso no mundo do trabalho deixa de ser uma alternativa para tornar-se uma necessidade imperiosa de sobrevivência. Para eles, a educação profissional integrada ao ensino de nível médio constitui, ao mesmo tempo, um direito básico e um plus que atende a uma necessidade social. É certo que, ao contrário do que procuram fazer crer os teóricos da renovação da Teoria do Capital Humano, nem a escolarização básica, nem tampouco a formação profissional, produzem empregos ou garantem empregabilidade. No entanto, é razoável admitir, num quadro de escassez dos empregos formais, que a educação profissional aliada a uma sólida educação básica poderá ensejar alternativas de constituição solidária e coletiva de trabalho e geração de renda, podendo contribuir, dessa forma, para a inserção e atuação cidadã no mundo do trabalho, com inclusão social, combate à discriminação e diminuição da vulnerabilidade das populações. 
Os autores pontuam que essa concepção se contrapõe às visões utilitaristas - pelas quais o jovem educando é reduzido à mera condição de capital humano em formação - e à educação como uma condição mercantil. A educação profissional, integrada à escolarização básica, constitui um processo formativo integral que busca compreender a problemática social do jovem como sujeito de direitos e de ações na sociedade e que busca contribuir para a sua inserção na vida adulta e no mundo do trabalho como cidadão e sujeito autônomo.

Nesse sentido, os autores destacam que:

\begin{abstract}
Em primeiro lugar, é necessário compreender o trabalho em sua dupla dimensão, estabelecendo a diferença entre sua condição ontológica de categoria constitutiva do ser social e sua forma histórica, degradada e alienada, sob o domínio das relações capitalistas de produção. $\mathrm{Na}$ primeira dimensão, o trabalho é processo coletivo e social mediante o qual o homem produz as condições gerais da existência humana, sendo fonte de produção de conhecimentos e saberes, portanto, principio educativo. O ser social que trabalha, o trabalhador, é sujeito da construção do mundo, tanto de sua produção material, quanto intelectual. A educação, tendo o trabalho como princípio educativo, é processo de humanização e de socialização para participação na vida social e, ao mesmo tempo, processo de qualificação para o trabalho, mediante a apropriação e construção de saberes e conhecimentos, de ciência e cultura, de técnicas e tecnologia (GARCIA; LIMA FILHO, 2004, p. 28).
\end{abstract}

Com relação à cultura, os autores propõem que é preciso considerá-la como complexo resultante dos processos de mediações e sínteses históricas nos quais a humanidade produz saberes, práticas e valores aos quais, em cada época e contexto, atribui significantes e significados às diversas dimensões e manifestações da vida social e individual, compreendendo as diferentes realidades (de nacionalidades, de etnias, de gênero, etc.), valorizando, portanto, a diversidade e a alteridade. $\mathrm{E}$ no que concerne à ciência e à tecnologia, estas são entendidas como extensão das possibilidades e potencialidades humanas.

Assim, o desenvolvimento científico e tecnológico é o desenvolvimento da ciência do trabalho produtivo, isto é, um processo de apropriação contínua de saberes e práticas pelo ser social no devir histórico da humanidade. A ciência e a tecnologia são, portanto, construções sociais complexas, forças intelectuais e materiais do processo de produção e reprodução social. No entanto, como processo social, participam e condicionam as mediações sociais, porém não determinam por si só a realidade, não são autônomas, nem neutras e nem 
somente experimentos, técnicas, artefatos ou máquinas: são saberes, trabalhos e relações sociais objetivadas (GARCIA; LIMA FILHO, 2004).

Assim, compreende-se, da discussão aqui apresentada, em torno das questões relativas à educação técnica e tecnológica no Brasil, que é preciso conjugar a atenção para com a história, para as condições materiais do presente e para o enfrentamento dos desafios trazidos pelo século XXI, e que colocam jovens e adultos diante de uma realidade complexa e cada vez mais aceleradamente mutante.

Nesse contexto, o ensino superior tecnológico (nova modalidade de ensino superior, que veio juntar-se definitivamente aos bacharelados e licenciaturas a partir da nova LDB) vem ganhando força, conforme já demonstrado pelos resultados do Censo da Educação Superior de 2013, apresentados no capítulo anterior.

Essa modalidade de ensino carrega também, como todas as outras, algumas das preocupações e problemas que devem estar presentes nas políticas de organização e gestão da educação e das organizações educacionais. Mas o pensar uma educação integral e cidadã, à altura dos desafios de nosso tempo e que busque contribuir para a superação de suas enormes e instigantes contradições - conforme propõem Garcia e Lima Filho (2004) - certamente passa pela construção de uma educação tecnológica que supere o utilitarismo e alcance - pela via das competências ou qualquer outra o seu objetivo final de oferecer uma formação plena, que agregue capital cultural e social a seus educandos, na direção de auxiliá-los a efetivamente vivenciarem possibilidades reais de mobilidade e transformação social.

No âmbito da educação profissional do SENAI, define-se competência profissional como a capacidade de mobilizar, articular e colocar em ação valores, conhecimentos e habilidades necessários para o desempenho eficiente e eficaz de atividades requeridas pela natureza do trabalho. Essa definição traz uma questão-chave quando se fala em competências: a mobilização, pressupondo que saberes - conhecimentos, habilidades e atitudes - só adquirem sentido quando mobilizados e articulados, permitindo enfrentar diferentes situações.

Nesse sentido, a estruturação de cursos e os programas do SENAI tem como ponto de partida os perfis baseados em competências profissionais 
demandadas pelo mundo do trabalho, o que viabiliza uma aproximação mais estreita entre a formação e as necessidades do setor produtivo.

O Curso Superior de Tecnologia em Produção de Vestuário $^{9}$ foi estruturado como um curso seriado, semestral, com 2.400 horas, mais 400 horas de estágio supervisionado, divididas em seis semestres, oferecendo 40 vagas por turma, com duas entradas anuais (janeiro e julho), por meio de processo seletivo próprio, sendo ofertado apenas no período noturno. O período mínimo de integralização previsto é de seis semestres, e o período máximo, 12 semestres.

No Projeto Pedagógico do Curso, está explicitado que sua finalidade era apoiar o desenvolvimento do setor do vestuário, "por meio da preparação de gestores de processos produtivos capazes de contribuir para a inserção das empresas brasileiras no cenário de competitividade gerado pela internacionalização da economia". O texto do Projeto também destaca o fato de que, tradicionalmente, os profissionais que atuam na gestão dos processos produtivos do vestuário têm formação em administração de empresas ou engenharia de produção. Em ambos os casos, a formação recebida não contempla conhecimentos específicos do setor, como criação e desenvolvimento, modelagem, costura industrial, corte de confecção industrial e outros. Além disso, aponta também que os cursos de moda, em geral, formam profissionais mais voltados para a criação e desenvolvimento do design, com uma visão superficial dos demais processos produtivos do setor.

O processo de criação de um curso, no âmbito do SENAI, inclui a formação de um Comitê Técnico Setorial, que constitui-se como grupo de discussão, composto por uma amostra estratificada de representantes da área de educação profissional e de representantes dos meios técnicos, das associações de classe e de empresas do segmento industrial em estudo, e que é encarregado de definir o perfil profissional visado, pesquisando o comportamento do mercado de trabalho e suas conexões com a educação profissional.

As tendências identificadas nesse fórum e as conclusões do Comitê Técnico Setorial resultam na definição de perfis de qualificações profissionais,

\footnotetext{
${ }_{9}^{9}$ Reconhecido pela Portaria MEC no 3.635, de 19/12/2002, publicada no D.O.U. de 20/12/2002.
} 
que constituem a base para a elaboração de desenhos curriculares, instrumentos de avaliação e, quando é o caso, certificação de competências.

As conclusões do Comitê Técnico Setorial encarregado de estruturar o perfil do Tecnólogo em Produção do Vestuário para a reformulação do curso oferecido pelo SENAI resultaram em uma organização curricular baseada em quatro eixos de competências: 1) planejamento do processo produtivo; 2) direção do processo produtivo; 3) controle do processo produtivo; 4) assessoria técnica, conforme mostrado nos Quadros 1 e 2 e no Anexo 3.

\section{Quadro 1 - Competências Profissionais - Geral}

\section{Competência Geral}

Planejar, dirigir e controlar o processo produtivo do vestuário, com visão estratégica e tática, e assessorar tecnicamente os diferentes setores da empresa, considerando os aspectos referentes à gestão da qualidade, aos princípios éticos e à responsabilidade socioambiental, com foco nos resultados organizacionais.

Fonte: SENAI, 2007.

\section{Quadro 2 - Competências Profissionais - Unidades de Competência}

\section{Unidades de Competência}

Unidade de Competência 1: Planejar o processo produtivo do vestuário, com visão estratégica e tática, considerando os aspectos referentes à gestão da qualidade, aos princípios éticos e à responsabilidade socioambiental, com foco nos resultados organizacionais.

Unidade de Competência 2: Dirigir o processo produtivo do vestuário, com visão estratégica e tática, considerando os aspectos referentes à gestão da qualidade, aos princípios éticos e à responsabilidade socioambiental, com foco nos resultados organizacionais.

Unidade de Competência 3: Controlar o processo produtivo do vestuário, com visão estratégica e tática, considerando os aspectos referentes à gestão da qualidade, aos princípios éticos e à responsabilidade socioambiental, com foco nos resultados organizacionais.

Unidade de Competência 4: Assessorar tecnicamente os diferentes setores da empresa, considerando os aspectos referentes à gestão da qualidade, aos princípios éticos e à responsabilidade socioambiental, com foco nos resultados organizacionais.

Fonte: SENAI, 2007.

As Unidades de Competência relativas ao Curso Superior de Tecnologia em Produção de Vestuário são ilustradas pelas Figuras 
Figura 2 - Criação e desenvolvimento do produto

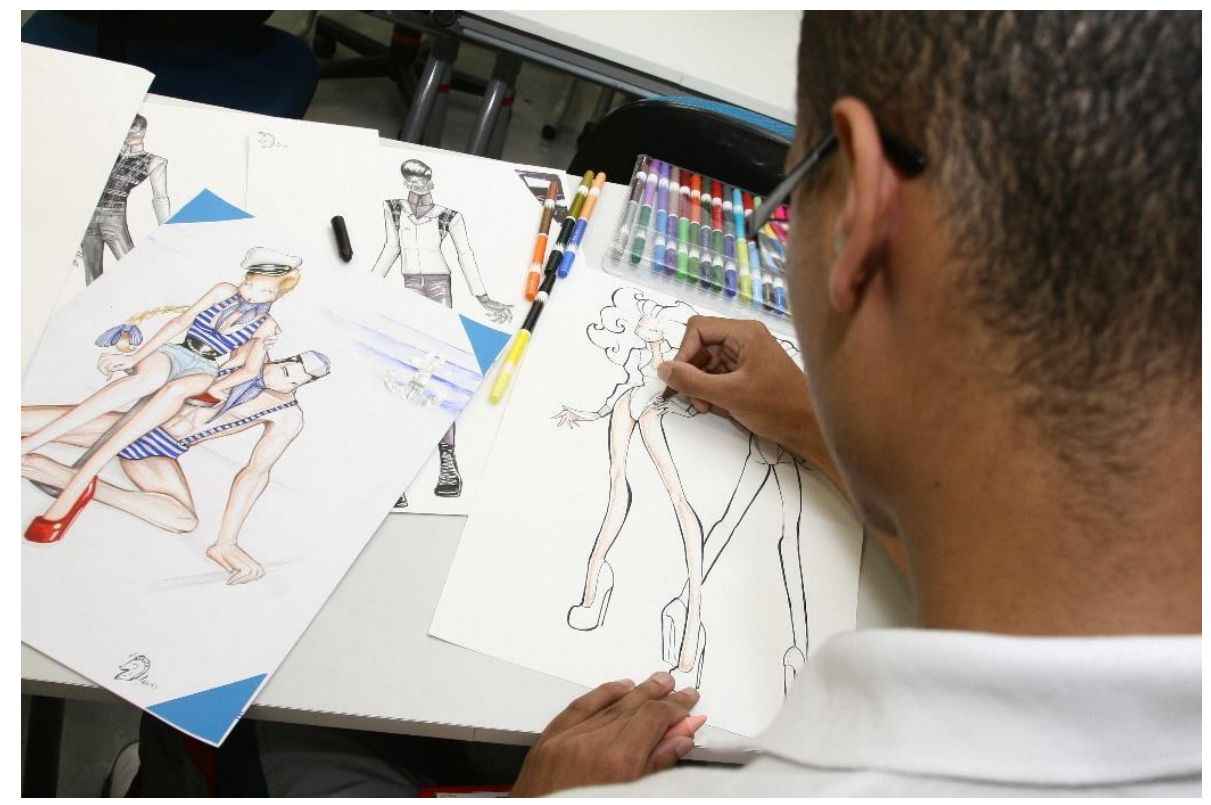

Fonte: o Autor.

Figura 3 - Modelagem
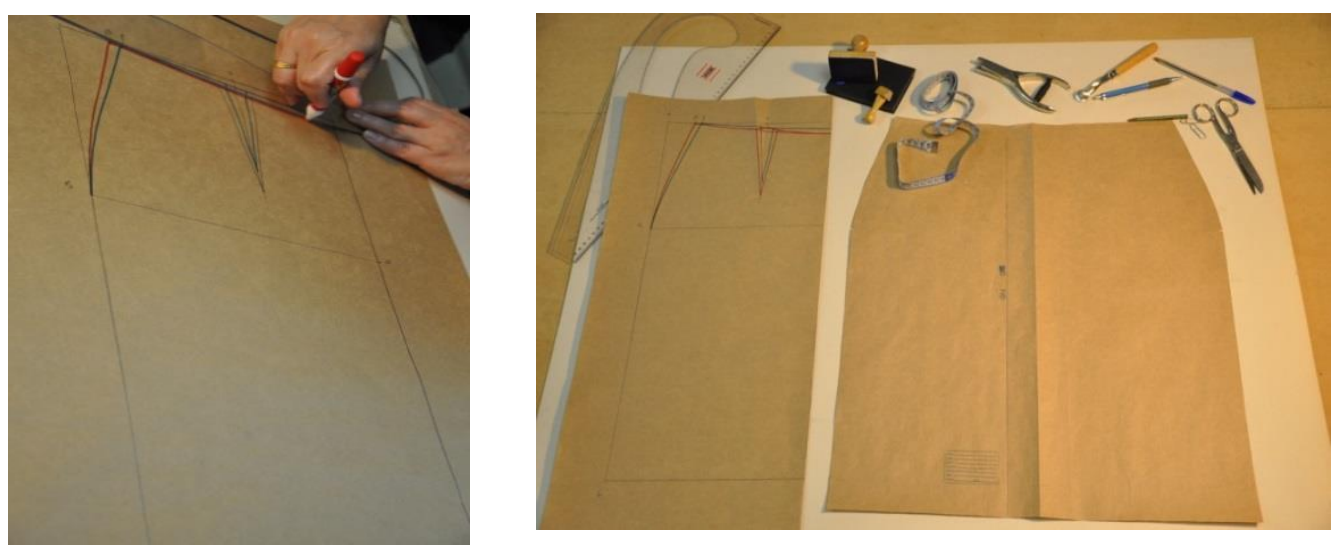

Fonte: o Autor. 
Figura 4 - Estudo de encaixe pelo sistema CAD

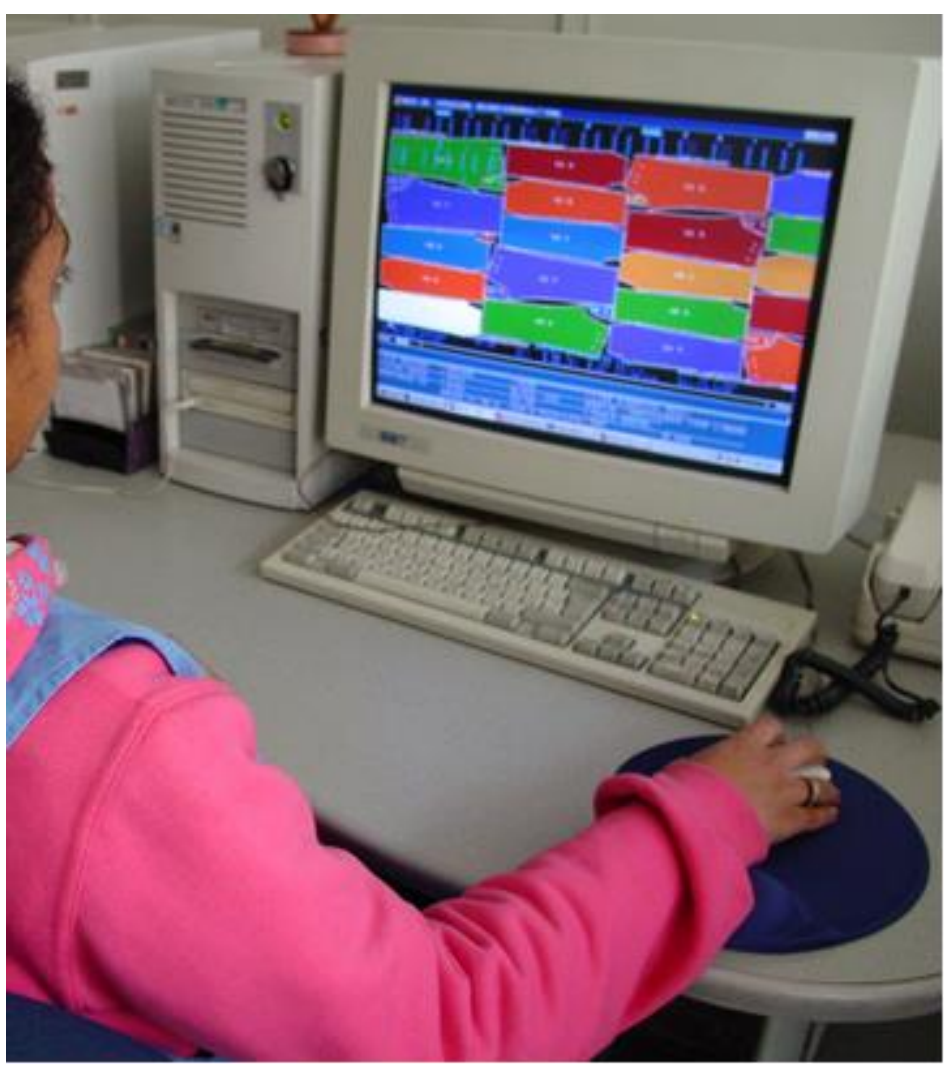

Fonte: o Autor. 
Figura 5 - Enfesto e corte

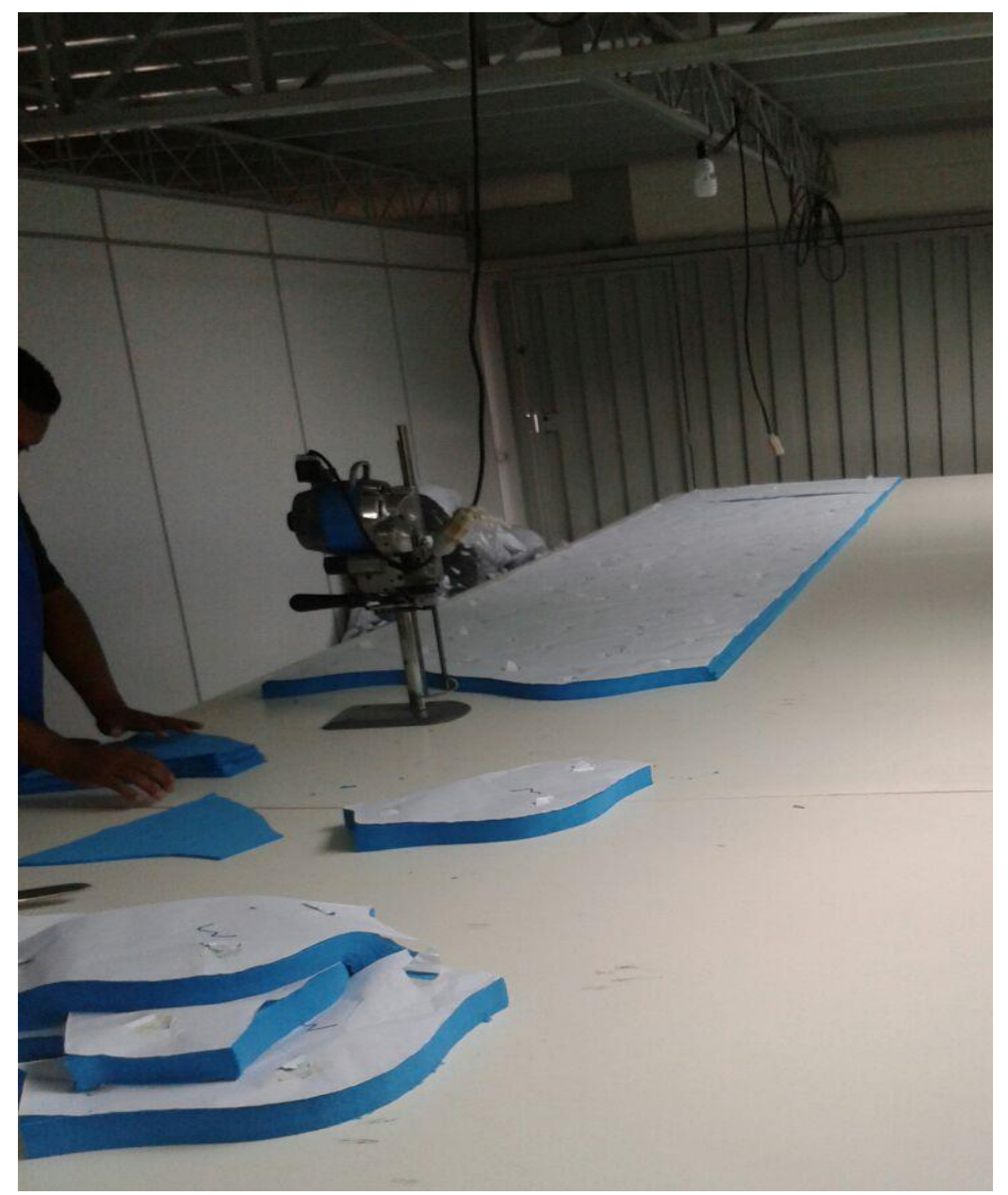

Fonte: o Autor. 
Figura 6 - Produção (Costura)

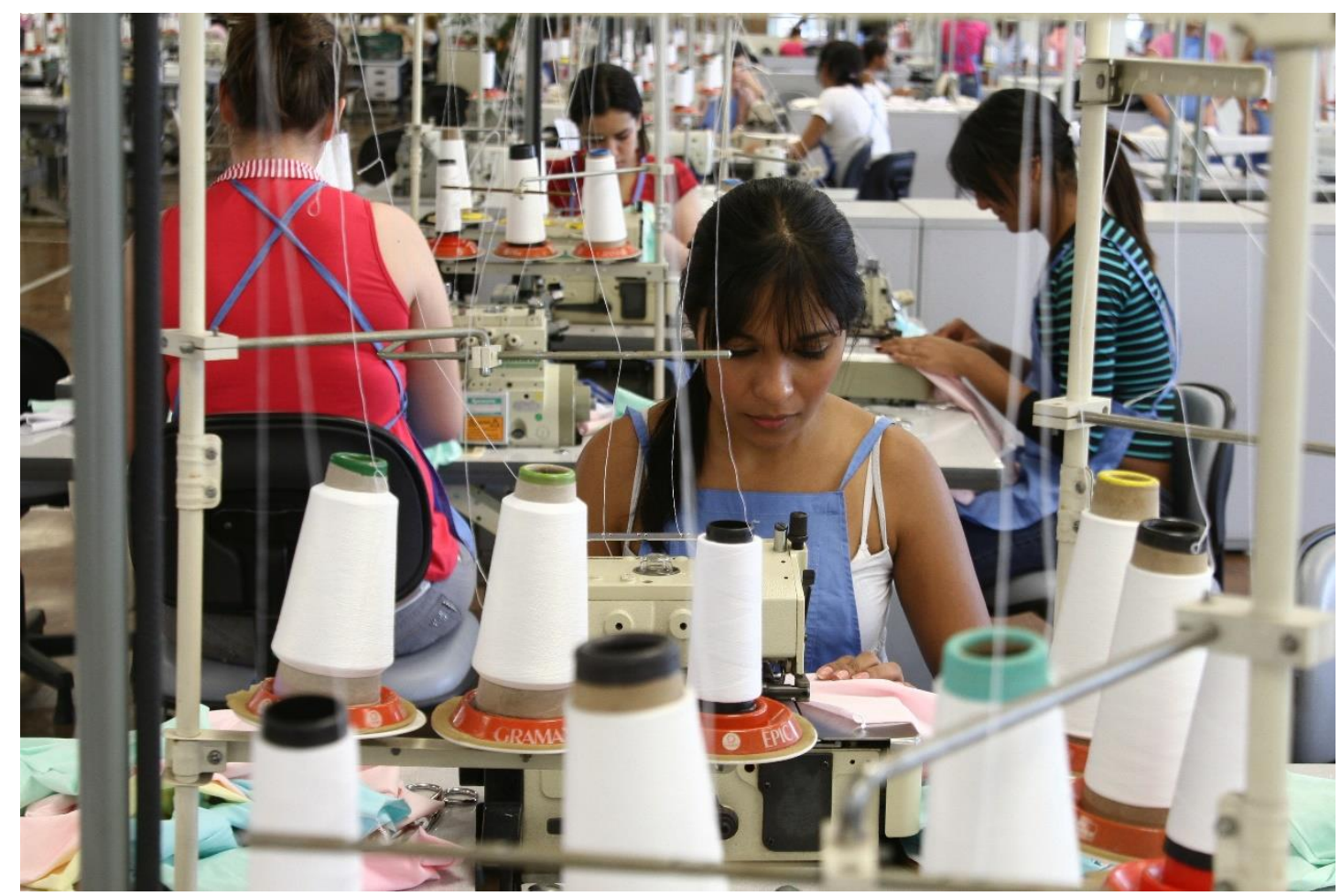

Fonte: o Autor.

Figura 7 - Controle da produção: cronoanálise

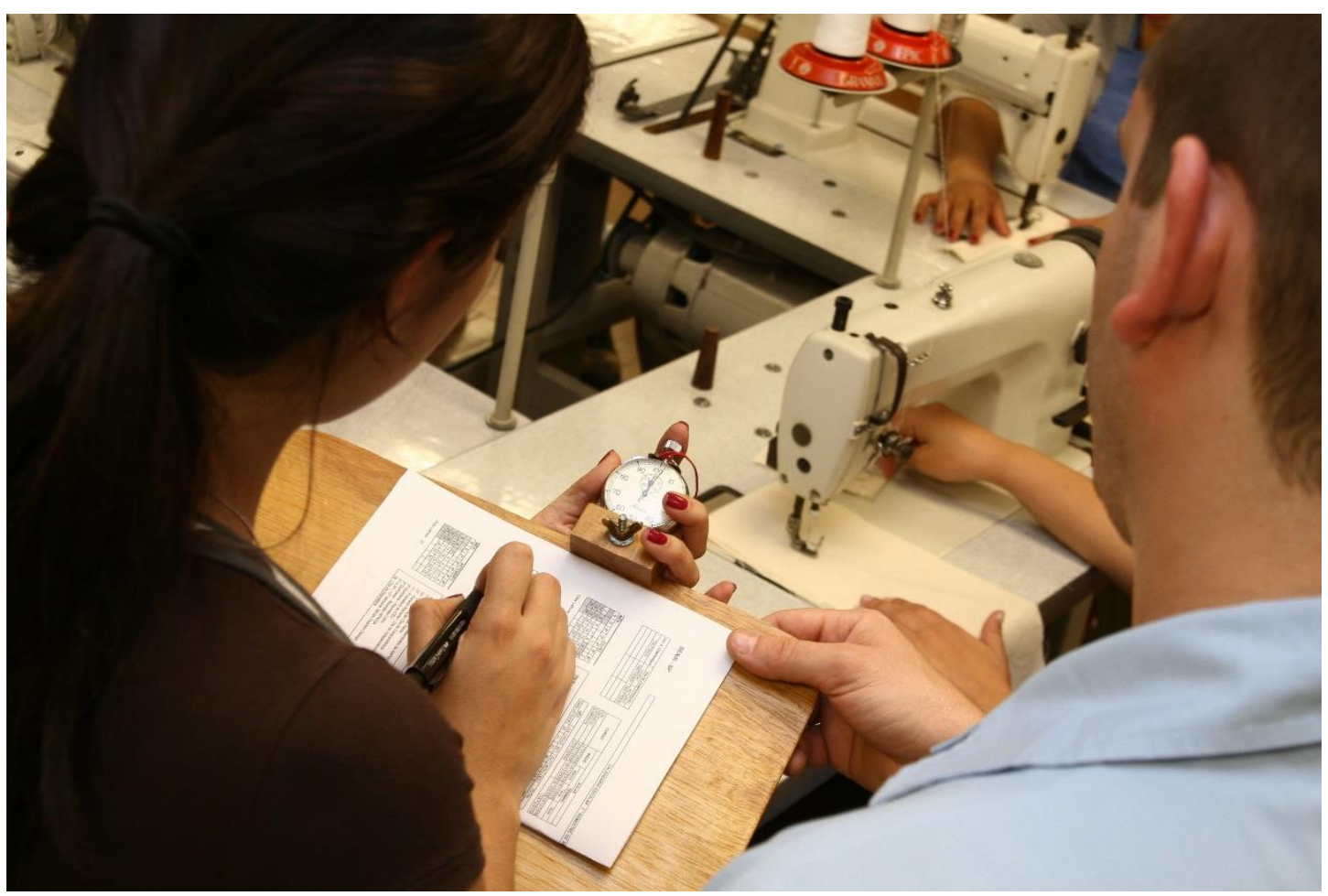

Fonte: o Autor. 
Essa estruturação diferenciada, baseada no modelo de educação por competências, demanda uma prática pedagógica também diferenciada, fazendo com que, ao planejar e desenvolver as aulas das diferentes unidades curriculares, os docentes enfatizem os fundamentos $\mathrm{e}$ as capacidades explicitadas nas ementas de conteúdos do Projeto de Curso. Além disso, as capacidades sociais, organizativas e metodológicas indicadas devem ser desenvolvidas com a utilização de diferentes estratégias, técnicas e dinâmicas, a serem implementadas no processo de ensino e aprendizagem, uma vez que são imprescindíveis para o desempenho dos futuros profissionais.

Essa estruturação também exige uma abordagem interdisciplinar por parte dos docentes, além do o emprego de métodos, estratégias e técnicas de ensino que levem o aluno a mobilizar conhecimentos, habilidades e atitudes no desenvolvimento de atividades típicas da área do vestuário, privilegiando a busca de alternativas para a resolução de problemas próprios do mundo do trabalho.

Por isso o curso trabalha com a formulação de situações-problema em todas as suas unidades curriculares, e estas devem se constituir em desafios que emulem aquelas situações encontradas no universo profissional. Segundo Macedo (2005b), os problemas estão acima dos exercícios, pois exercícios podem ser apenas repetições e situações-problema envolvem o planejamento, a tomada de decisão, a análise do contexto, além do desenvolvimento de habilidades e competências. Portanto, situações-problema necessitam ser criadas, inovadas e devem ter relação com o cotidiano do educando, para que assim possam ser desenvolvidas novas habilidades e competências (SILVA; FELICETTI, 2014).

O planejamento do curso também prevê que devem ser propostas situações de ensino-aprendizagem que possibilitem a realização de pesquisas científicas, sejam de campo, dadas pelas características da área do vestuário, sejam bibliográficas, propiciadas pelo incentivo a leituras técnicas, incluindo-se o uso da internet. Por meio dessa estratégia, pretende-se que o aluno exercite o desenvolvimento da iniciativa, a tomada de decisão, a criatividade, o relacionamento, a liderança e a ética, contribuindo para o desenvolvimento das competências de gestão, identificadas claramente no perfil profissional estabelecido para o Tecnólogo em Produção de Vestuário (Anexo 3). 
Finalmente, cabe enfatizar que essa forma de desenvolvimento curricular demanda a realização da avaliação por competências, com a proposta de situações-problema, simuladas ou reais, que exijam a mobilização de conhecimentos, habilidades e atitudes, uma vez que a avaliação da aprendizagem, nesse contexto, é considerada como um meio de coleta de informações para a melhoria do ensino e da aprendizagem, tendo as funções de orientação, apoio e assessoria, e não apenas a decisão final a respeito do desempenho do aluno.

Dessa forma, entende-se que o egresso desse curso será um profissional com competências adequadas ao mercado de trabalho, mas também um cidadão que, a partir de seu senso crítico, será capaz de atuar não apenas em função de uma mobilidade social caracterizada pelo progresso material, mas também, como apontado por Lemos, Dubeux e Pinto (2009), de reconhecer outros ganhos trazidos pela sua formação e trabalhar com o objetivo mais amplo de melhorar a realidade à sua volta. 


\section{A PESQUISA}

\subsection{Cenário e Metodologia}

Esta pesquisa foi realizada com 72 egressos do Curso Superior de Tecnologia em Produção de Vestuário, oferecido pela Faculdade de Tecnologia SENAI Antoine Skaf, localizada no bairro do Brás, na capital paulista, um curso formatado dentro do conceito de educação por competências (adotado pela instituição em todos os seus cursos) e já descrito no capítulo anterior.

Em relação à metodologia, este estudo foi delineado como uma pesquisa de caráter exploratório e descritivo.

A pesquisa exploratória, segundo Cervo e Bervian (2002), tem como principal característica a possibilidade de o pesquisador familiarizar-se com 0 fenômeno a ser estudo, sem necessariamente levantar hipóteses. Os autores afirmam que o estudo exploratório é recomendado em situações em que há poucas abordagens acadêmicas disponíveis sobre o tema, como é o caso do tema aqui abordado.

De acordo com Cervo e Bervian (2002, p. 67), "a pesquisa descritiva, em suas diversas formas, trabalha sobre dados ou fatos colhidos da própria realidade", observando, registrando, analisando e correlacionando fatos ou fenômenos sem manipulá-los.

Como parte do estudo descritivo, foram realizadas uma pesquisa bibliográfica, para embasamento teórico das questões aqui discutidas, e uma pesquisa documental, utilizando os relatórios da pesquisa SAPES, realizada pelo SENAI junto a seus egressos, conforme descrição a seguir.

O SAPES - Sistema de Acompanhamento de Egressos do SENAI foi implantado em 1985 pelo Departamento Regional de São Paulo (DR-SP), com o objetivo de avaliar o impacto dos cursos oferecidos pela instituição na vida profissional dos egressos, sob o ponto de vista da laboralidade e da promoção socioprofissional, além de aferir o grau de satisfação da clientela-aluno e da clientela-empresa com os serviços educacionais prestados.

A partir de 1999, sob a coordenação do Departamento Nacional do SENAI (DN), a avaliação foi adotada por todas as Diretorias regionais, sendo aplicada 
trienalmente. Durante os primeiros 15 anos de realização da pesquisa, a mala direta foi bastante eficaz, em que pese sua limitação como estratégia de coleta de dados. A partir dos anos 2000, seu retorno foi declinando, o que inviabilizou a obtenção de resultados estatisticamente válidos. Em função disso, a partir de 2005 o questionário passou a ser aplicado por telefone, com amostras estratificadas segundo as modalidades integrantes da oferta regular de cursos: Aprendizagem, Técnico e Superior de Tecnologia.

A pesquisa apresentada neste trabalho utilizou o relatório publicado pelo SENAI em junho de 2013, referente aos egressos de 2012 (concluintes em dezembro de 2011). Esse relatório apresenta os resultados da pesquisa telefônica realizada com uma amostra de 2.753 egressos que haviam completado, em dezembro de 2011, o último período dos cursos de Aprendizagem Industrial (CAI), Técnico (CT) e Superior de Tecnologia (CST), de uma população de 12.409 concluintes. Os dados do SAPES referentes aos egressos dos Cursos Superiores de Tecnologia e, especificamente, do Curso Superior de Tecnologia em Produção de Vestuário, foram utilizados como medida de comparação com os dados levantados na pesquisa realizada pelo autor.

A pesquisa realizada com os egressos do Curso Superior de Tecnologia em Produção de Vestuário da Faculdade de Tecnologia SENAI Antoine Skaf foi aplicada em duas etapas. Na primeira, foi aplicado o Questionário A (Anexo 1), enviado por e-mail a ex-alunos formados a partir de 2011, que obteve 50 respostas.

Na segunda etapa, foram entrevistados 22 ex-alunos também formados a partir de 2011. Essas entrevistas foram realizadas no período de março a junho de 2016, por diversos meios, em função da disponibilidade dos entrevistados: telefone, e-mail, mensagem instantânea, redes sociais e pessoalmente, em encontros realizados entre o pesquisador e o entrevistado. Para cada entrevistado, foi proposto um roteiro básico de perguntas (para evitar dispersão), conforme mostrado no Anexo 2, mas também foi permitido que falassem mais livremente sobre a sua vida profissional e pessoal após o curso, apontando sua percepção pessoal a respeito do grau de mobilidade social proporcionado pela formação conquistada. 
Conforme já explicitado anteriormente, essa amostra foi definida a partir do número de alunos formados no período estudado (2011 a 2015). Nesses cinco anos, o curso teve, em média, 50 concluintes por ano, totalizando 250 concluintes no período. A amostra buscou abranger pelo menos $20 \%$ desse total.

É importante salientar que, durante essas entrevistas, não se discutiu conceitos de mobilidade social, nem se questionou o que essa expressão (mobilidade social) significava para o entrevistado. Na maior parte dos casos, a expressão não foi usada. A pergunta geralmente utilizava a forma assinalada no roteiro de entrevista, isto é, questionava-se a percepção do egresso a respeito de uma possível "melhoria de vida" associada à conclusão do curso. Assim, o que se obteve dos participantes foi uma percepção pessoal sobre a influência do curso em sua própria vida.

Embora várias perguntas tenham sido feitas, no sentido de buscar conhecer e caracterizar melhor os participantes, tanto na primeira quanto na segunda etapa da pesquisa (Anexos 1 e 2), os dados a serem apresentados concentram-se em três categorias de análise, que pareceram mais relevantes ao autor para a discussão de sua hipótese: a primeira categoria é a experiência profissional prévia ao início do curso (se ela existe e em qual área) e depois do curso; a segunda refere-se aos níveis de renda pessoal (não familiar) do participante, no momento do início e após o término do curso (expressos em faixas de salários mínimos); a terceira considera os benefícios apontados pelos participantes (escolhidos de uma lista na primeira etapa, e nomeados espontaneamente na segunda) como advindos do fato de terem conseguido se formar nesse curso.

Além disso, foram consideradas também mais três categorias relativas à escolarização formal do egresso e de sua família, e à profissão dos pais, uma vez que, de acordo com os autores utilizados neste estudo (RIBEIRO, 2014; MACHADO, 2012; BRESSER-PEREIRA, 1974; NORONHA e BARBOSA, 2016), a escolaridade dos pais é um fator de alta relevância para a mobilidade social.

Essa escolha de categorias de análise deve-se ao objetivo do estudo, que é contribuir para a análise sobre a educação tecnológica, com ênfase na área de moda e vestuário, discutindo a importância do processo de ensino-aprendizagem nessa área para a mobilidade social de seus estudantes. Além disso, dentro da pesquisa realizada, são essas categorias que emergem, à luz da revisão da 
literatura realizada a respeito dos três temas norteadores da investigação: mobilidade social, educação tecnológica e educação por competências.

Os resultados serão apresentados na seguinte ordem: em cada uma das três primeiras categorias de análise, serão mostrados primeiramente os dados do SAPES, em seguida os da primeira etapa da pesquisa e, finalmente, aqueles obtidos na segunda etapa da investigação.

Em seguida, serão apresentadas as três categorias de análise que consideram apenas as duas etapas da pesquisa realizada neste trabalho, uma vez que os dados referentes a essas categorias não estão presentes na pesquisa SAPES.

\subsection{Resultados e Discussão}

\section{Experiência profissional do egresso antes e depois do curso}

\section{SAPES}

Da amostra de 2.753 egressos que haviam completado, em dezembro de 2011, o último período dos cursos de Aprendizagem Industrial (CAI), Técnico (CT) e Superior de Tecnologia (CST), de uma população de 12.409 concluintes, em média $84,1 \%$ dos indivíduos amostrados já contavam com alguma bagagem profissional antes do ingresso na graduação tecnológica, sendo que em 72,7\% dos casos, essa experiência profissional era na própria área do curso ou em área correlata.

\section{Pesquisa Etapa 1}

Entre os 50 respondentes da primeira etapa da pesquisa, 28 (56\%) atuavam como empregados na área do vestuário; 8 (16\%) eram empregados em outras áreas; 1 (2\%) estava desempregado; 4 (8\%) eram empresários; 7 (14\%) eram estudantes e $3(6 \%)$ classificavam-se como "outros", conforme mostra o Gráfico 1 (p. 64). 
Gráfico 1 - Situação profissional antes do curso - Etapa 1

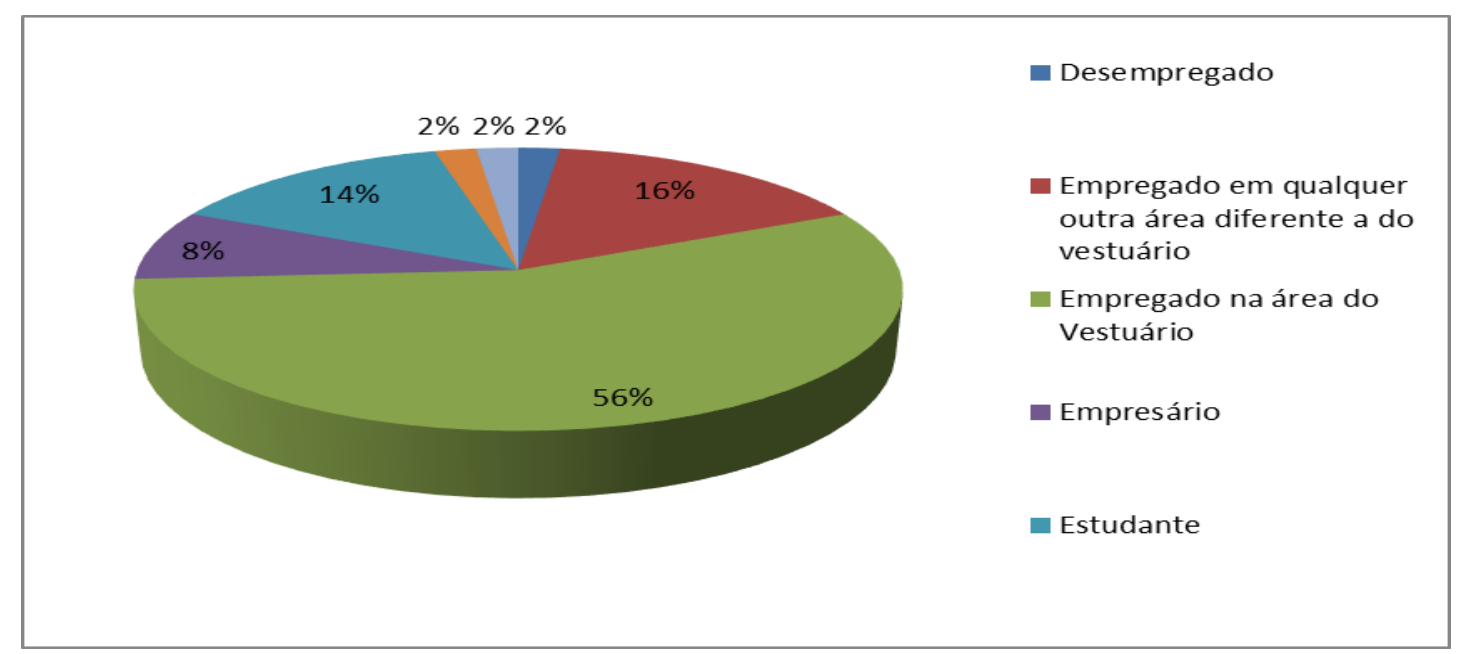

Fonte: o Autor.

\section{Pesquisa Etapa 2}

Entre os 22 respondentes da segunda etapa da pesquisa, $14(66,7 \%)$ atuavam como empregados (na área do vestuário ou outras); 3 (14,3\%) eram estudantes; 2 (9,5\%) estavam desempregados. Havia ainda 1 empresário e 1 profissional autônomo, ambos atuando na área do curso, e 1 não respondeu à pergunta, conforme mostra o Gráfico 2.

\section{Gráfico 2 - Situação profissional antes do curso - Etapa 2}

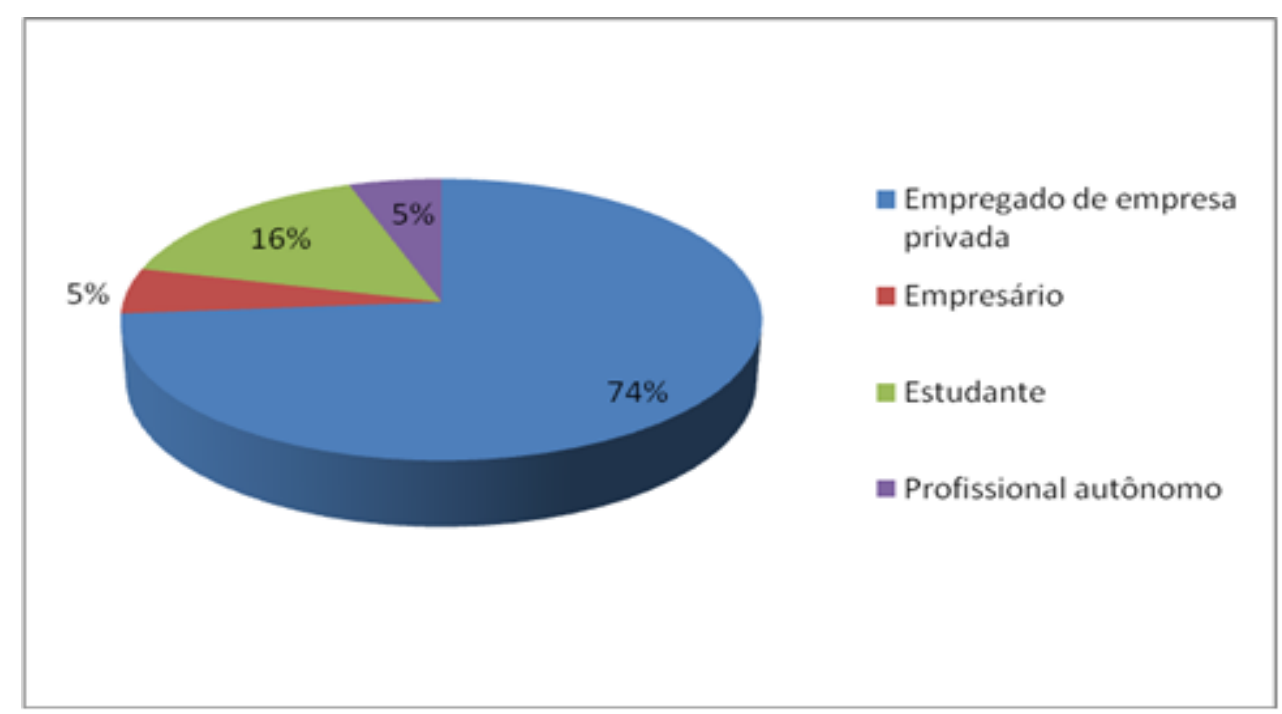

Fonte: o Autor. 
Em relação à situação profissional após o curso, os resultados se apresentam conforme mostrado a seguir.

\section{SAPES}

A Tabela 3 mostra que, na pesquisa do SAPES, dos respondentes da área Têxtil e Vestuário, 100\% encontravam-se trabalhando na área no momento da pesquisa, mas o questionário não especifica em quais cargos ou áreas funcionais.

Tabela 3 - Distribuição dos egressos ocupados, por tipo de experiência, no momento da pesquisa

\begin{tabular}{|c|c|c|c|c|c|c|c|}
\hline \multicolumn{8}{|c|}{ Superior - Formação de Tecnólogo } \\
\hline $\begin{array}{c}\text { Áreas } \\
\text { Ocupacionais }\end{array}$ & Na área & $\%$ & $\begin{array}{c}\text { Fora da } \\
\text { área }\end{array}$ & $\%$ & $\begin{array}{c}\text { Total } \\
\text { considerado } \\
\text { (B) }\end{array}$ & \begin{tabular}{|c} 
Total de \\
entrevistados \\
(A)
\end{tabular} & $\begin{array}{c}\text { Taxa de } \\
\text { ocupação } \\
(B / A)^{*} 100\end{array}$ \\
\hline $\begin{array}{l}\text { Têxtil e } \\
\text { Vestuário }\end{array}$ & 16 & 100,0 & & & 16 & 17 & 94,1 \\
\hline
\end{tabular}

Fonte: SENAI, 2015.

\section{Pesquisa Etapa 1}

O Gráfico 3 mostra que, dos 50 respondentes da Etapa 1 da pesquisa aqui realizada, $8 \%$ não estavam trabalhando no momento da pesquisa, mas entre os restantes, $74 \%$ trabalhavam no setor operacional e 18\% no setor administrativo, mas todos na área Têxtil e Vestuário.

\section{Gráfico 3 - Situação profissional após o curso - Etapa 1}

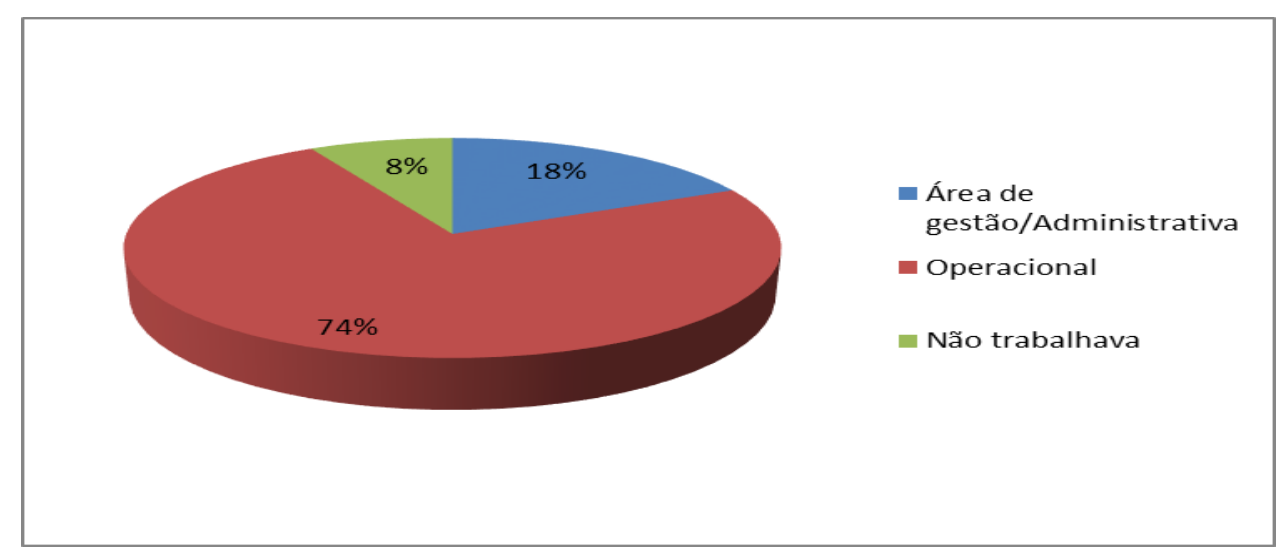

Fonte: o Autor. 


\section{Pesquisa Etapa 2}

Dos 22 entrevistados da segunda etapa da pesquisa, 5\% revelaram trabalharem como funcionários públicos no momento da pesquisa. Todos os demais estavam atuando na área Têxtil e Vestuário, sendo que $42 \%$ como empregados de empresas privadas, $42 \%$ como profissionais autônomos e $11 \%$ como empresários, conforme mostra o Gráfico 4.

\section{Gráfico 4 - Situação profissional após o curso - Etapa 2}

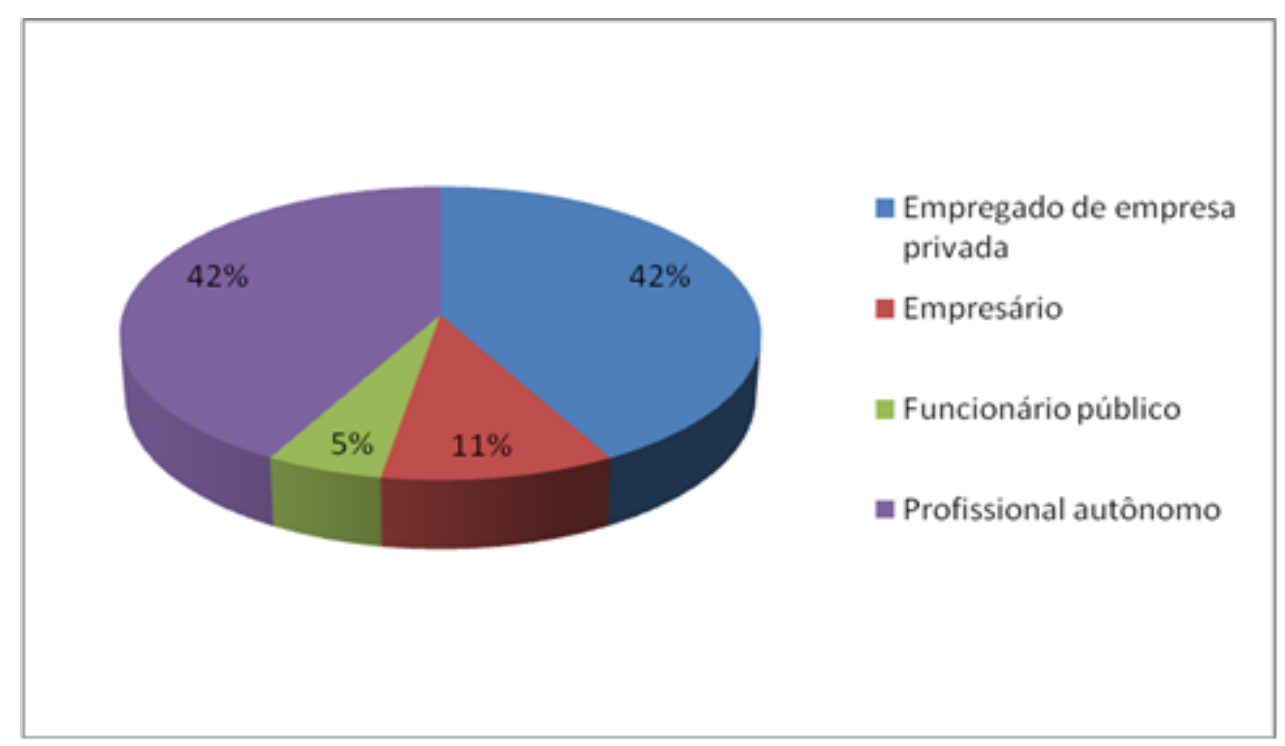

Fonte: o Autor.

Níveis de renda pessoal (não familiar) do egresso no início e no final do curso

\section{SAPES}

A pesquisa Sapes não mostra os níveis de renda dos egressos antes ou no momento do início de seus respectivos cursos superiores de tecnologia no SENAI, mas mostra que, na média, os egressos atuantes em sua área de formação ou em área relacionada apresentavam, no momento da pesquisa, renda pessoal mensal $28,1 \%$ superior (4,93 salários mínimos) à daqueles que exerciam atividades profissionais fora de sua área de estudo (3,85 salários mínimos). A pesquisa mostra ainda que a média salarial geral dos egressos dos cursos superiores de tecnologia era, no momento da pesquisa, de 4,66 salários mínimos. 


\section{Pesquisa Etapa 1}

No início do curso, entre os 50 sujeitos da primeira etapa, 22 (44\%) tinham renda mensal na faixa de 1 a 2 salários mínimos; 18 (36\%), na faixa de 2 a 5 salários mínimos; 4 (8\%), 5 a 7 salários mínimos; 2 (4\%), 7 a 10 salários mínimos; e $4(8 \%)$ declararam não possuir renda pessoal (dependiam dos pais), conforme demonstrado no Gráfico 5.

\section{Gráfico 5 - Nível de renda pessoal antes do curso - Etapa 1}

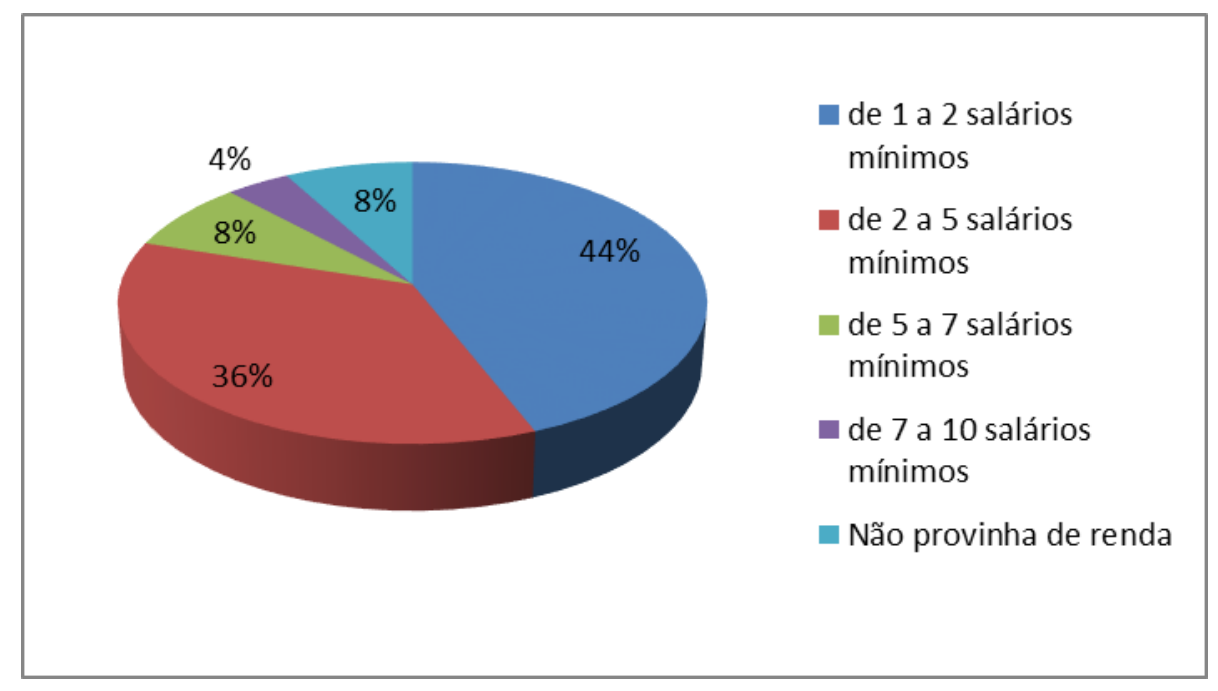

Fonte: o Autor.

Após a conclusão do curso, 9 (18\%) declaravam possuir renda na faixa de 1 a 2 salários mínimos; 26 (52\%), de 2 a 5 salários mínimos; 11 (22\%), de 5 a 7 salários mínimos; 1 (2\%), de 7 a 10 salários mínimos, e 3 (6\%) declararamse sem renda pessoal no momento da pesquisa, como mostra o Gráfico 6 ( $p$. 73). 


\section{Gráfico 6 - Nível de renda pessoal após o curso - Etapa 1}

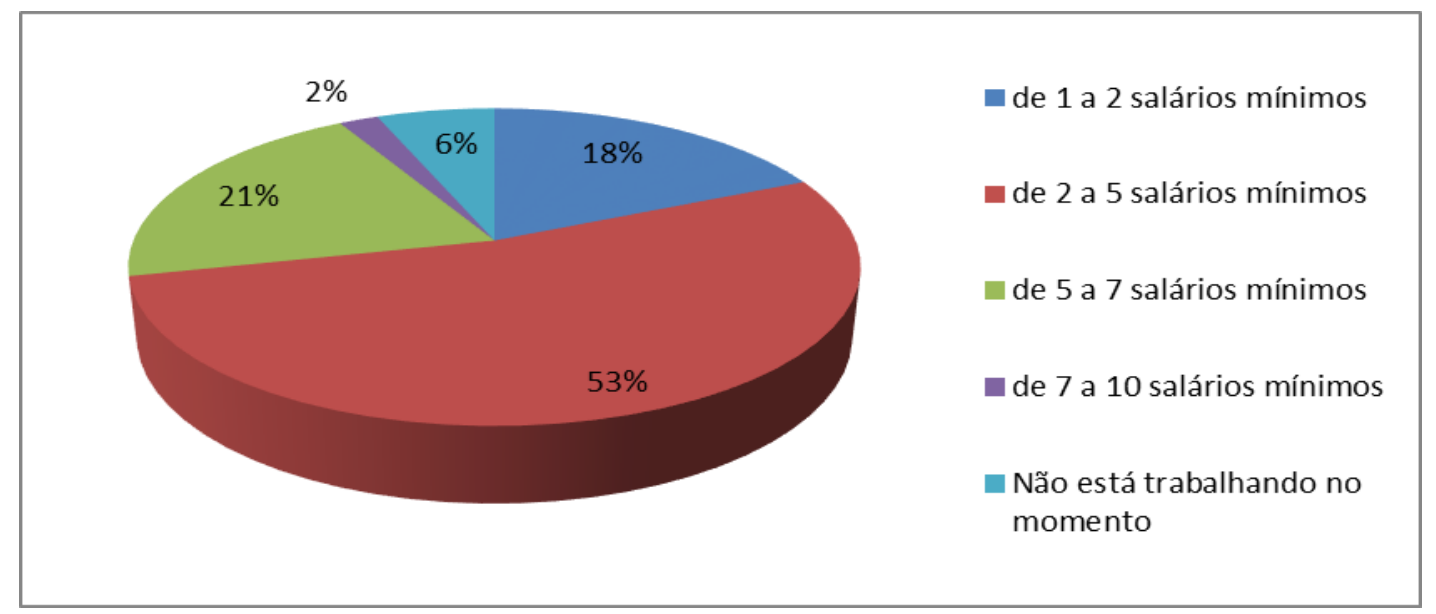

Fonte: o Autor.

\section{Pesquisa Etapa 2}

No início do curso, entre os 22 sujeitos da segunda etapa, $11(52,4 \%)$ declararam ter renda mensal na faixa de 1 a 2 salários mínimos; 6 (28,6\%), de 2 a 5 salários mínimos; 2 (9,5\%), de 5 a 7 salários mínimos; 1 de 7 a 10 salários mínimos, 1 acima de 10 salários mínimos e 1 não respondeu à pergunta, conforme mostra o Gráfico 7.

\section{Gráfico 7 - Nível de renda pessoal antes do curso - Etapa 2}

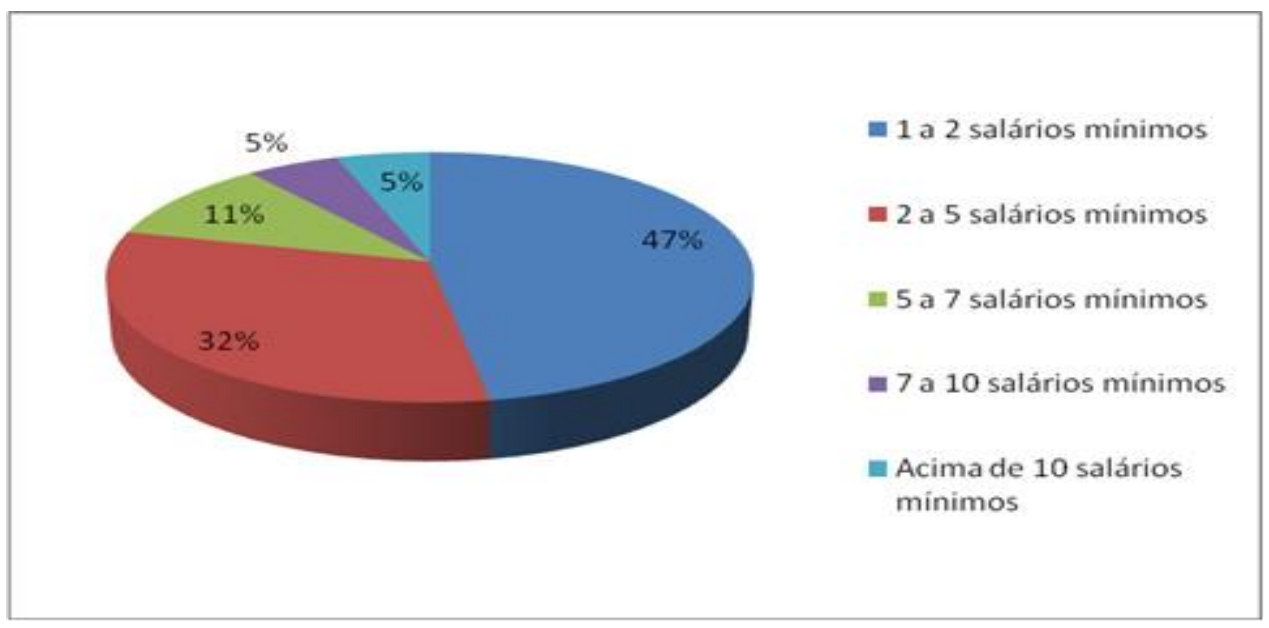

Fonte: o Autor.

No final do curso, dos 22 respondentes da Etapa 2, 41\% declararam possuir renda mensal de 2 a 5 salários mínimos; 18\%, de 1 a 2 salários mínimos; 
14\%, de 5 a 7 salários mínimos, e outros $14 \%$, de 7 a 10 salários mínimos; apenas $4 \%$ declararam possuir renda acima de 10 salários mínimos, e $9 \%$ não responderam, como mostra o Gráfico 8.

Gráfico 8 - Nível de renda pessoal após o curso - Etapa 2

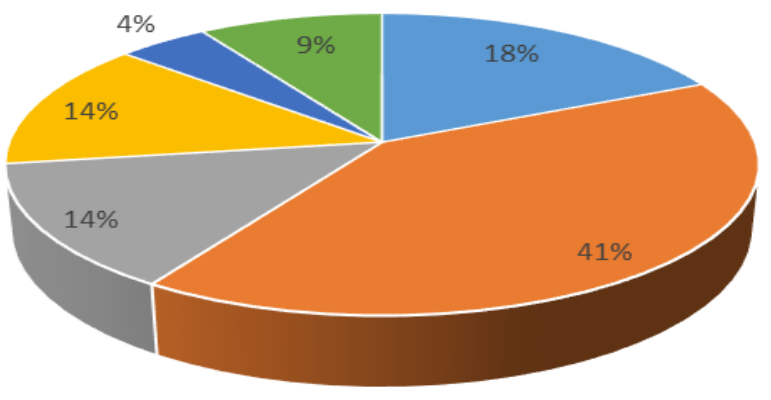

- 1 a 2 salários mínimos

- 2 a 5 salários mínimos

- 5 a 7 salários mínimos

- 7 a 10 salários mínimos

- Acima de 10 salários mínimos

- Não responderam

Fonte: o Autor.

\section{Benefícios trazidos pela realização do curso}

Essa questão não é contemplada pela pesquisa SAPES, que se concentra mais nas questões de emprego, função, satisfação dos alunos-clientes com os cursos oferecidos e disposição de realizar novos cursos na instituição. Mas 0 relatório chama a atenção para o significativo percentual de egressos, entre os que tiveram alguma experiência profissional pós-curso, que ainda permaneciam na mesma empresa no momento da pesquisa telefônica. Tal fato é indicativo de seu bom desempenho, e aponta para oportunidades mais imediatas de início de carreira, tão logo se complete a formação profissional inicial do alunado parecendo corroborar a hipótese de que essas modalidades são importante porta de entrada para o mercado de trabalho qualificado e mais bem remunerado.

Relativamente à pesquisa realizada especificamente para este estudo, essa questão revelou-se a mais importante, principalmente quando se procede à comparação entre as respostas obtidas, respectivamente, nas Etapas 1 e 2 da investigação. 
A Tabela 4 mostra as respostas a uma questão específica presente no questionário aplicado a 50 egressos, e que permitia a escolha de quantas alternativas o respondente quisesse. Em função da forma de aplicação (questionário eletrônico, enviado por e-mail ou mensagem instantânea), é possível apenas perceber, nesse ponto, as escolhas relativas às questões materiais e de renda, sem a possibilidade de discutir com cada participante 0 significado real e individual das conquistas assinaladas.

\section{Tabela 4 - Resposta relativas à Etapa 1 da pesquisa}

O que você pode apontar como benefícios trazidos pela realização do curso? (Assinale quantas alternativas quiser)

\begin{tabular}{|c|c|c|}
\hline Inserção no mercado de trabalho & $\overline{7}$ & \\
\hline Mudança para um emprego melhor & $\overline{21}$ & \\
\hline Permanência no mercado de trabalho & $\overline{20}$ & \\
\hline Melhoria salarial & $\overline{13}$ & \\
\hline Melhoria do seu desempenho profissional & $\overline{24}$ & \\
\hline Abertura de empresa própria & 8 & \\
\hline Aquisição de imóvel(is) & 7 & \\
\hline Aquisição de automóvel(is) & $\overline{14}$ & \\
\hline Outros & 23 & \\
\hline
\end{tabular}

Por outro lado, os participantes da Etapa 2 tiveram a oportunidade de responder à mesma questão, mas acompanhada da possibilidade de explanarem, da forma como quisessem, o significado dessas conquistas para a sua vida. Com isso, foi possível dimensionar, de forma mais efetiva, a percepção de "mobilidade social" presente no imaginário de cada indivíduo (Tabela 5). 
Tabela 5 - Respostas relativas à Etapa 2 da pesquisa

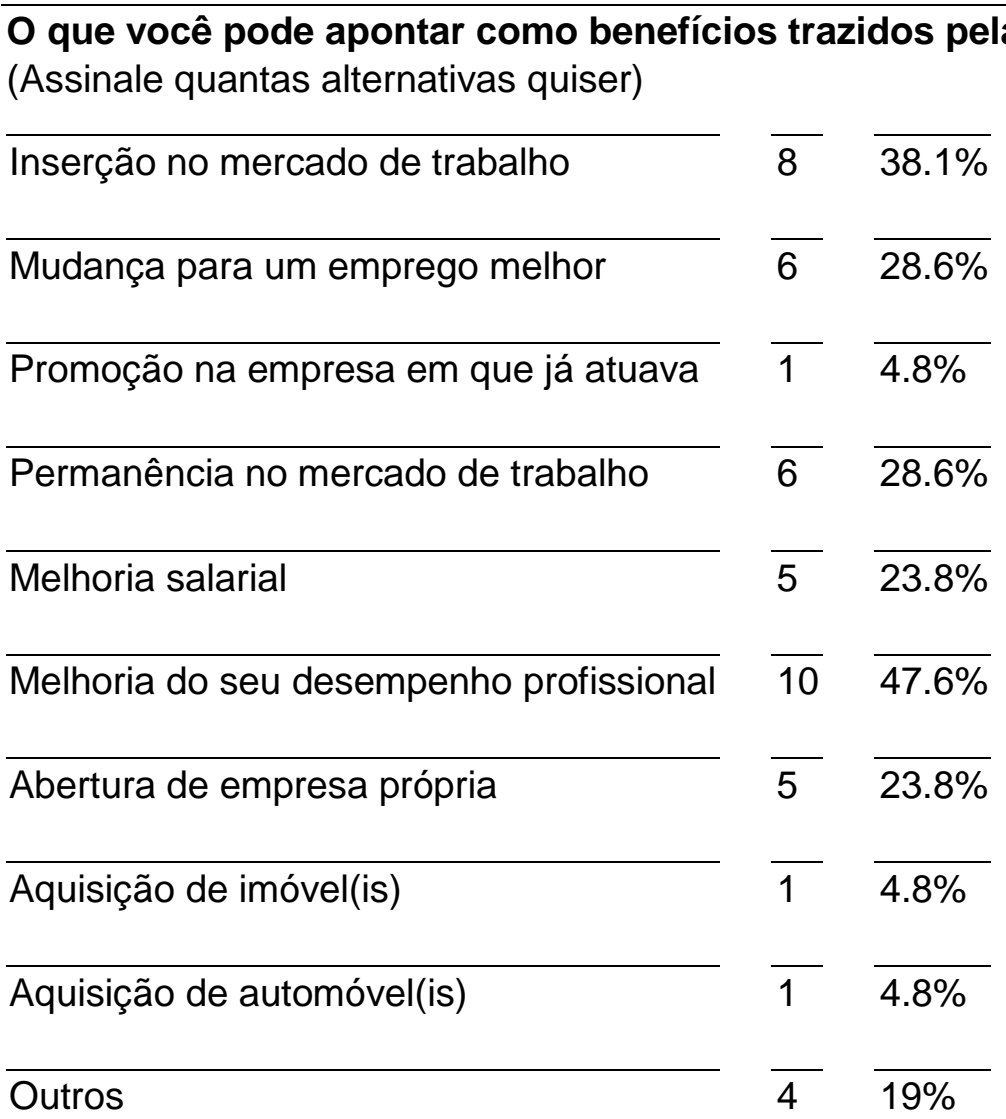

A percepção de mobilidade social enquanto fator associado à renda pessoal, ao status representando pelos bens materiais e pela posição econômica alcançada pelo indivíduo apareceu, principalmente, nas falas dos respondentes que relataram a aquisição de bens (automóvel e imóvel), a inserção no mercado de trabalho, a mudança para um emprego melhor.

No entanto, foi possível também captar a presença de outra percepção relativa à mobilidade social, já apontada por Lemos, Dubeux e Pinto (2009): a da mudança de status relacionada à posição do indivíduo em função de sua profissão, ocupação ou papel no grupo. A melhoria do desempenho profissional, a construção de novos conhecimentos, a formação de uma rede de contatos pessoais e profissionais, o fato de serem os primeiros em suas famílias a conquistarem um diploma de ensino superior, foram alguns dos fatores 
mencionados pelos entrevistados como pontos positivos associados à conclusão do curso, e percebidos por eles como indicadores de mobilidade social.

A mobilidade social que caracteriza a trajetória desses jovens deve ser pensada a partir de suas biografias e das respectivas trajetórias familiares, conforme pontua Barros (2010), no sentido de compreender como jovens oriundos de famílias de baixa escolaridade, com condições de trabalho precárias, entraram para a universidade e estão buscando postos de trabalho que mais se aproximam de suas aspirações profissionais e financeiras, identificadas pelo prestígio e status, e a que custo eles estão fazendo isso.

Vários dos autores aqui estudados (RIBEIRO, 2014; MACHADO, 2012; BRESSER-PEREIRA, 1974; NORONHA e BARBOSA, 2016) atribuem à educação uma possibilidade de melhoria do acesso a bens materiais e culturais, e essa fala é reproduzida no discurso positivo dos jovens sobre a aquisição de capital educacional e cultural. Muitos declararam sentir-se orgulhosos de serem os primeiros de suas famílias a se diplomarem num curso superior.

Outra categoria de análise que demonstrou sua importância após a revisão da literatura a respeito de mobilidade social foi a escolaridade dos pais que, segundo Ribeiro (2014), é um dos fatores fundamentais para a mobilidade do tipo intergeracional.

Nos Gráficos 9 e 10, relativos à primeira etapa da pesquisa (50 respondentes), é possível observar que o Ensino Fundamental, incompleto ou completo, é o nível de escolarização mais comum entre os pais dos egressos. A porcentagem de pais e mães que chegaram ao Ensino Médio (completo ou incompleto) é bem mais baixa, e se torna ainda menor em relação ao Ensino Superior e à pós-graduação. 
Gráfico 9 - Nível de escolaridade do pai - Etapa 1

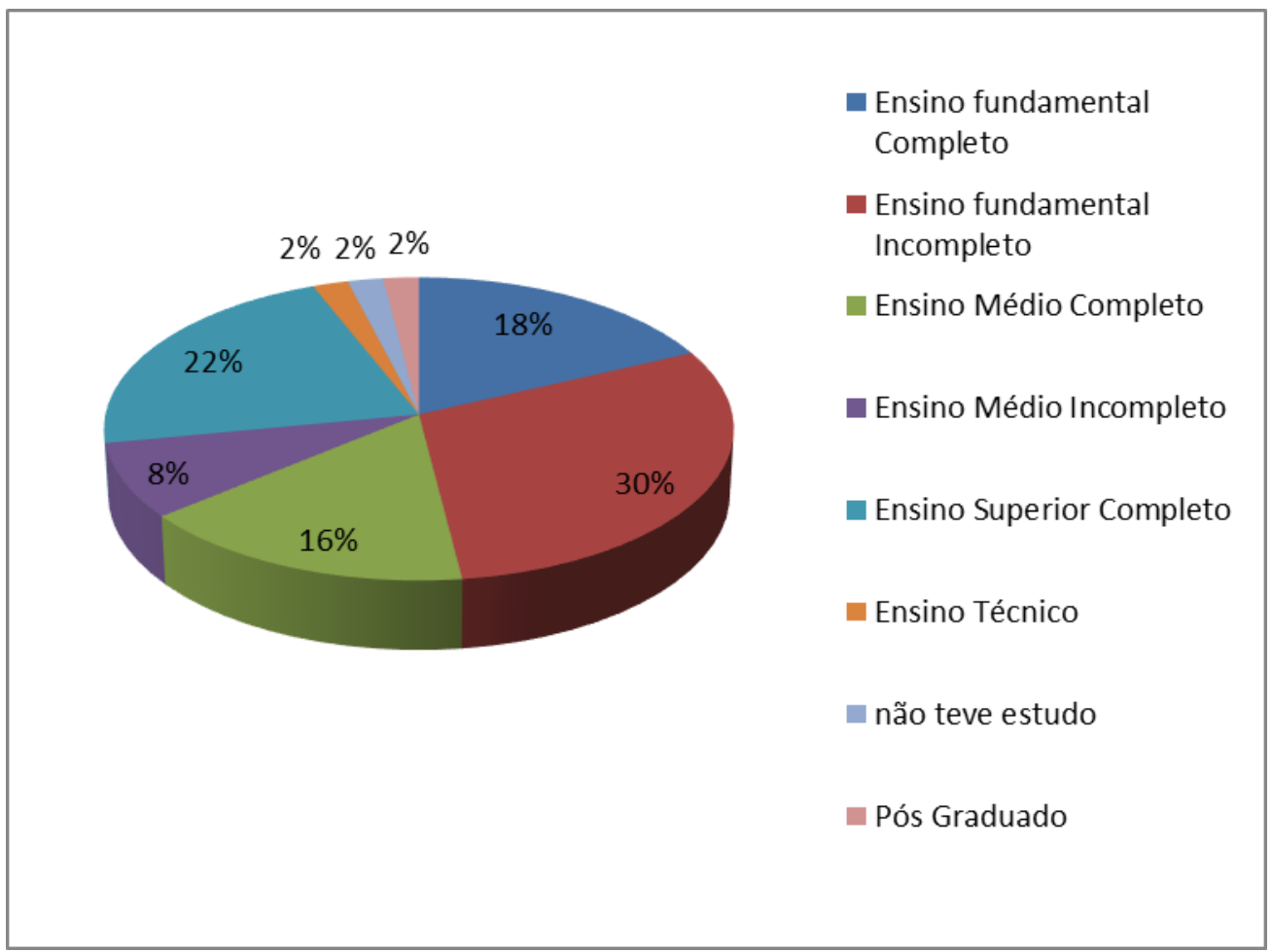

Fonte: o Autor.

\section{Gráfico 10 - Nível de escolaridade da mãe - Etapa 1}

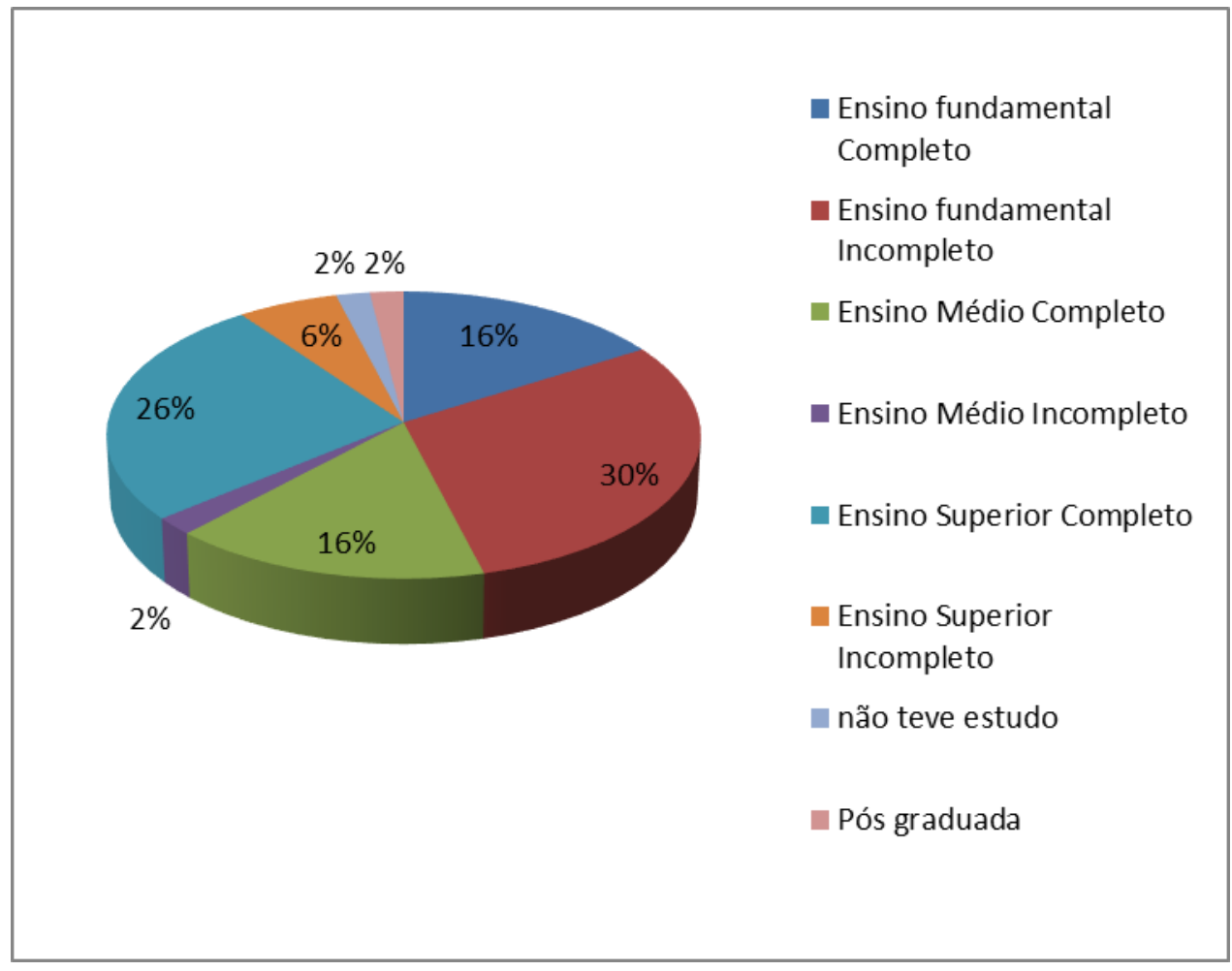

Fonte: o Autor. 
Nos Gráficos 11 e 12, relativos à segunda etapa da pesquisa (22 respondentes), é possível observar que as porcentagens não diferem muito, ou seja, ao completar o curso superior, a maioria dos egressos participantes deste estudo chegou a um nível de escolaridade superior ao de seus pais, e consegue perceber essa variável como um sinal de mobilidade social.

\section{Gráfico 11 - Nível de escolaridade do pai - Etapa 2}

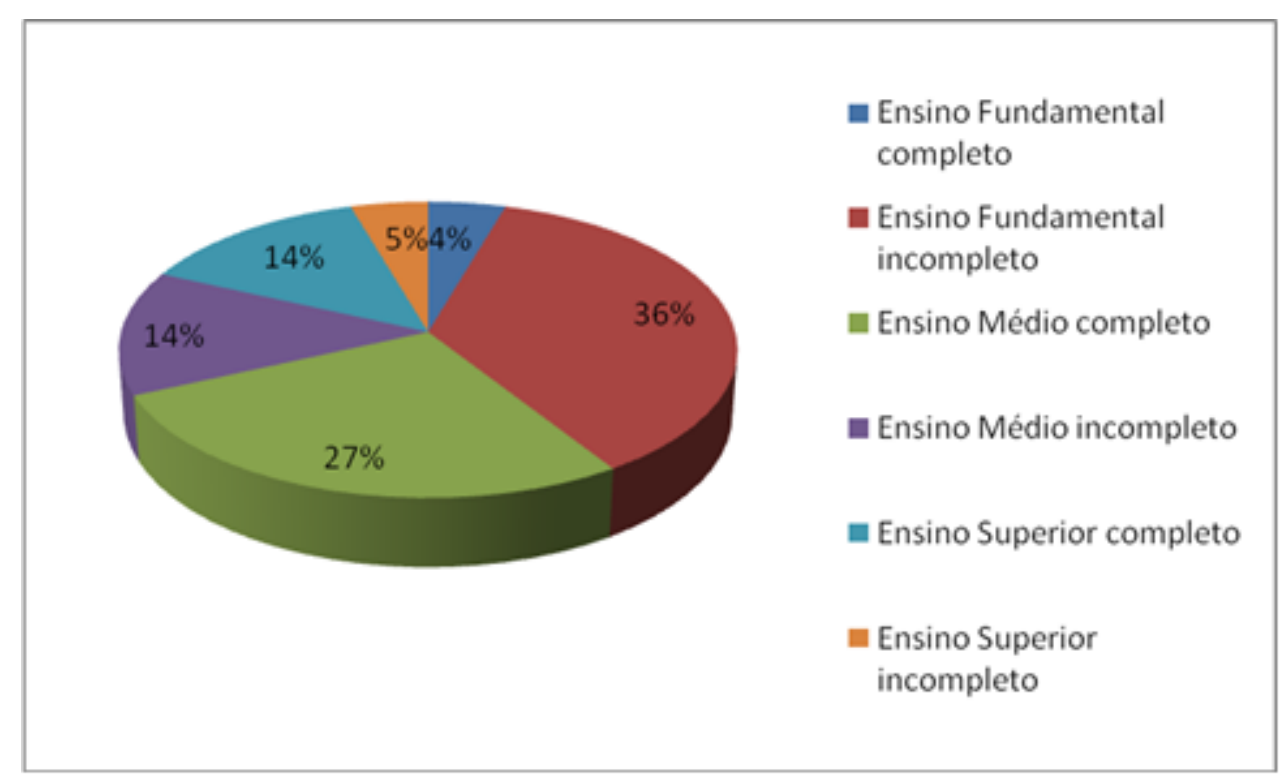

Fonte: o Autor.

\section{Gráfico 12 - Nível de escolaridade da mãe - Etapa 2}

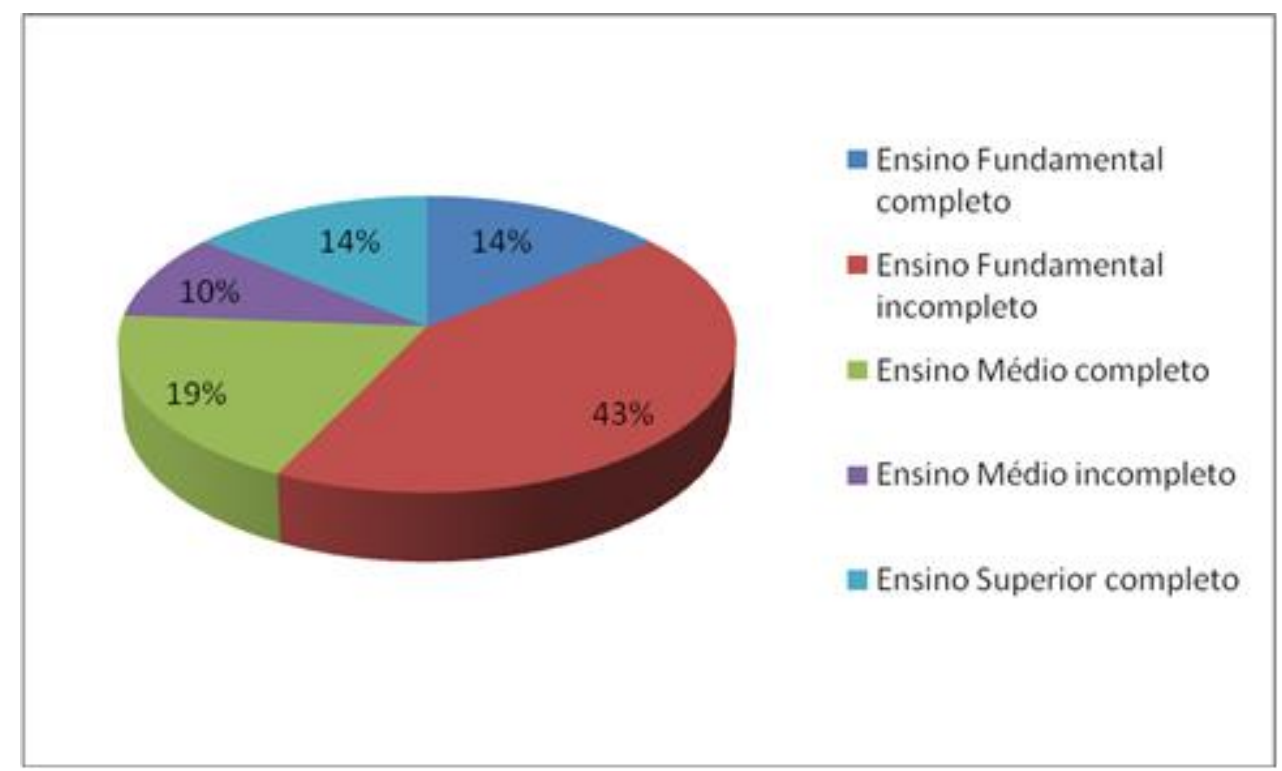

Fonte: o Autor. 
No estudo de Barros (2010), assim como na investigação aqui apresentada, a mobilidade social é percebida na comparação com a geração dos pais, em primeiro lugar, e depois com sua própria infância e com outros segmentos sociais, em função das condições de acesso ao ensino superior e ao consumo. Comprar computador, televisão, aparelho de som, pagar por suas próprias viagens e lazer, fazer planos de adquirir um carro ou um imóvel, os colocam, segundo suas avaliações, nos patamares das camadas médias.

Mas além disso, os participantes desta pesquisa, sem exceção, mencionaram, com maior ou menor ênfase, ganhos não materiais associados à oportunidade de frequentar um curso superior: uma nova visão de mundo, a "abertura da cabeça" - que leva sempre a um projeto de continuidade de estudos - e a possibilidade de lutar por melhores posições no mercado de trabalho completam a percepção de mobilidade social apresentada por eles.

Isso pode ser percebido na comparação entre a profissão ou cargo ocupado pelos pais e mães dos respondentes, tanto na Etapa 1 quanto na Etapa 2 da pesquisa, mostrados nos Gráficos 13 e 14, a seguir, e a própria posição profissional do egresso, antes e depois do início do curso, conforme já mostrado anteriormente, nos Gráficos 1, 2, 3 e 4.

\section{Gráfico 13 - Profissão do pai - Etapas 1 e 2}

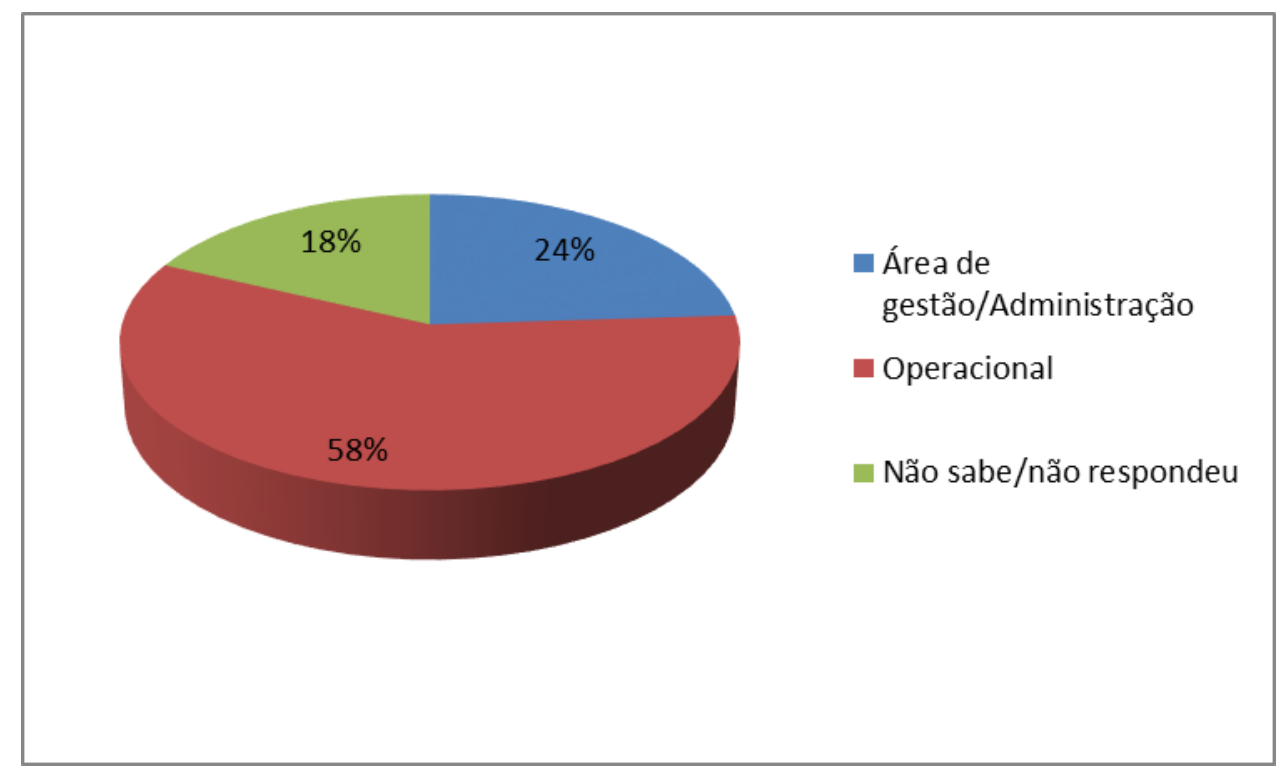

Fonte: o Autor. 


\section{Gráfico 14 - Profissão da mãe - Etapas 1 e 2}

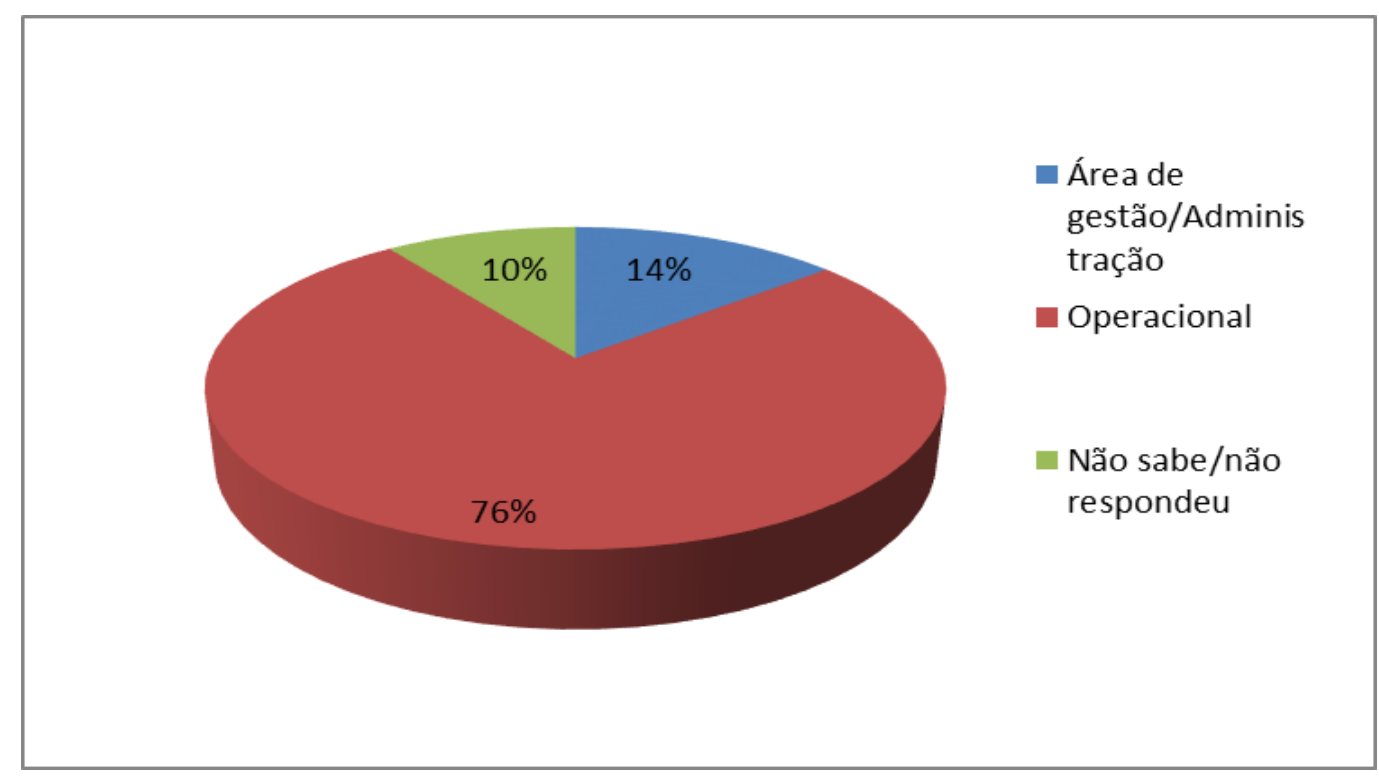

Fonte: o Autor.

Na finalização deste capítulo, parece importante salientar que, conforme mostrado no capítulo 3, o número de instituições de ensino superior cresceu muito no País a partir do ano 2000, principalmente em função de programas oficiais como o Plano de Desenvolvimento da Educação (PDE 2001-2010).

Como parte do PDE foram criados o REUNI - Programa de Reestruturação e Expansão das Universidades Federais, que além das 14 novas universidades criadas e da ampliação das universidades existentes, prevê a expansão dos cursos noturnos, a ampliação da mobilidade estudantil, a revisão da estrutura acadêmica e a diversificação das modalidades de graduação, propondo uma reestruturação não apenas de ordem quantitativa, mas também qualitativa.

Também faz parte dessa iniciativa o PROUNI, programa de bolsas de estudos criado em 2005, com o objetivo de estabelecer que as instituições beneficiadas por isenções fiscais concedam bolsas a alunos carentes, na proporção dos alunos pagantes por curso e turno, além da reestruturação e maior injeção de recursos no FIES, programa de financiamento estudantil do governo federal.

Todos essas iniciativas buscam a reestruturação da educação superior nacional pela articulação de dois princípios: democratização do acesso 
conjugada à justiça social, aumentando o contingente de estudantes menos favorecidos economicamente com acesso ao ensino superior. No entanto, é forçoso notar que o número de instituições, cursos e vagas oferecidas cresceu muito mais no âmbito da educação superior privada do que na pública.

Assim, ainda que amparado por programas como o PROUNI e o FIES, os estudantes provenientes da classe trabalhadora ainda encontram muitas dificuldades, não apenas para ingressar, mas principalmente para se manter no ensino superior, e essa é uma realidade que afeta diretamente suas possibilidades de mobilidade social.

Por outro lado, os níveis salariais dos profissionais que conseguem terminar o ensino superior são muito mais altos do que os dos demais níveis de escolaridade, conforma mostram dados coletados pelo SEMESP, relativos a 2012 e 2013 (Gráfico 15).

\section{Gráfico 15 - Níveis de remuneração por escolaridade}

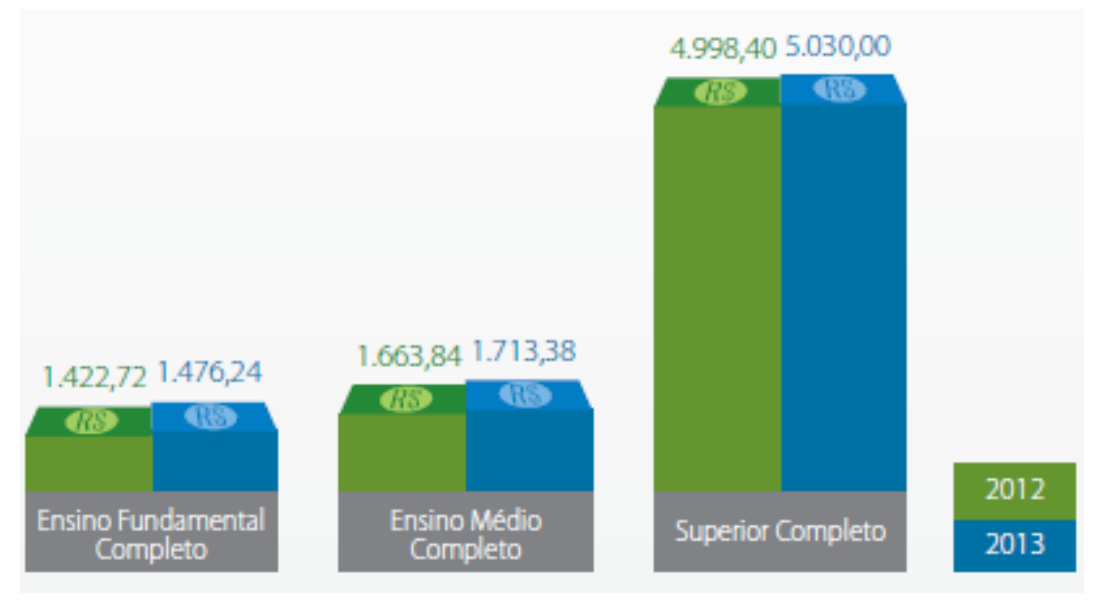

Fonte: SEMESP, 2015.

Também a pesquisa SAPES mostra que, na média, os egressos atuantes na sua área de formação ou em área relacionada auferiam renda $28,1 \%$ superior à daqueles em atividades profissionais fora as área de estudos, considerando o momento de realização da pesquisa. Os valores, em salários mínimos ( $S M=R \$$ 690,00 ), eram de 4,93 e 3,85 , respectivamente. A média geral apurada foi de 4,66 salários mínimos.

Portanto, é compreensível que os jovens tenham transformado o "fazer faculdade" em objeto de desejo e de consumo, uma vez que o diploma do ensino 
superior Ihes permite vislumbrar uma vida melhor, isto é, maiores possibilidades de mobilidade social, não só em relação à geração de seus pais, mas também em relação aos integrantes de sua própria geração. 


\section{CONSIDERAÇÕES FINAIS}

Este trabalho começou com a percepção empírica do pesquisador a respeito da realidade à sua volta. Sendo ele próprio oriundo de família muito humilde, o autor credita o sucesso de sua própria trajetória pessoal à oportunidade que teve de estudar no SENAI e, posteriormente, tornar-se coordenador do Curso Superior de Produção de Vestuário nessa mesma instituição.

Na função de coordenador, ele pode conviver e observar muito de perto diversas trajetórias semelhantes à sua. Dessa observação nasceu a pesquisa, que acabou por se constituir em seu trabalho de Mestrado.

A hipótese considerada no delineamento deste estudo foi a de que 0 ensino e a aprendizagem de moda, por parte de jovens e adultos oriundos das classes emergentes, por meio do modelo de educação profissional por competências oferecido pelo SENAI, pode constituir-se efetivamente num meio de mobilidade social, uma vez que esse modelo torna-se mais significativo para o aluno porque propõe a construção do conhecimento a partir das reais demandas do mercado, além de oferecer uma formação intelectual ampla, voltada à formação do estudante autônomo e do profissional crítico e criativo.

O objetivo do estudo, então, concentrou-se na verificação dessa hipótese, por meio da realização de uma de pesquisa aplicada, de campo, empírica, efetivada a partir de análises documentais, questionários e entrevistas, e precedida de uma revisão da literatura centrada nos temas focais do trabalho.

Ao longo da revisão da literatura, foi possível observar, com Ribeiro (2014), que existe um padrão de associação entre origem e destino de classe sugere que a diminuição da desigualdade de renda que vem ocorrendo no Brasil afeta pouco as pessoas que têm origem de classe na elite. Assim, no que diz respeito às chances de mobilidade social, pessoas com origem na elite têm enormes vantagens. As mudanças que ocorreram nas últimas décadas afetam principalmente quem está nas classes abaixo, mas não os filhos das classes mais abastadas.

Com Bresser-Pereira (1973), foi possível visualizar que o baixo índice de desenvolvimento econômico e o correspondente baixíssimo grau de instrução do povo brasileiro (quando se sabe que a educação é a melhor via para a 
mobilidade social), são também grandemente responsáveis pela falta de mobilidade social existente no Brasil. É indiscutível, porém, que a distribuição da renda extremamente desigual existente no País, a qual é fundamentalmente consequência de um sistema capitalista de relações de produção em que a propriedade se encontra altamente concentrada, está na base dessa baixa mobilidade social. Só causas profundas desse tipo podem explicar uma desigualdade de oportunidades tão grande como a existente no Brasil. E tudo indica que o simples desenvolvimento econômico, desacompanhado de transformações estruturais no sistema de propriedade e de distribuição da renda, dificilmente implicará em modificar, significativamente, essa situação.

Todos os autores estudados apontam que há muita desigualdade de oportunidades no Brasil. Quanto mais altas as classes de origem, maiores as chances de seus membros permanecerem ou alcançarem classes de destino mais altas. Os modelos usados pelos autores para analisar a associação entre origem e destino de classe indicam que há fortes barreiras à mobilidade intergeracional. Essas barreiras tornam-se relativamente permeáveis, na medida em que as pessoas avançam no sistema educacional, mas não são completamente eliminadas pela educação.

A educação é uma das maneiras de transpor essas barreiras, mas não elimina o efeito da classe de origem. Mesmo quando incluída a escolaridade dos indivíduos nos modelos, o efeito das classes de origem permaneceram significativos e relativamente fortes. Em suma, para tornar a sociedade brasileira mais igualitária, é necessário desenvolver mais o sistema educacional, mas também diminuir a desigualdade de condições entre as classes sociais.

Discutindo o modelo de educação por competências usado pelo SENAI instituição na qual a pesquisa foi realizada - foi possível perceber, na revisão da literatura, que o modelo não é uma unanimidade entre os pensadores da educação brasileira; que muitos não o consideram o modelo ideal, uma vez que, para eles, a questão das competências - ou "aprender a aprender", conforme pontuado por Duarte (2001) e Frigotto (2000) - está associada a um modelo neoliberal de economia, que pensa no trabalhador apenas como "capital humano" e propõe uma educação voltada exclusivamente para o desenvolvimento de habilidades que atendam às demandas do mercado. 
No entanto, realizando a pesquisa empírica com os egressos do Curso Superior de Produção de Vestuário da Faculdade de Tecnologia SENAI Antoine Skaf, localizada no bairro do Brás, em São Paulo, foi possível observar que, para os indivíduos que lograram diplomar-se no curso, essa realização é fortemente percebida como um movimento de mobilidade social.

As conquistas materiais estão bastante presentes nas falas dos entrevistados, como exemplo das melhorias conquistas a partir da conclusão do curso, mas eles também mencionam a construção de conhecimentos, a formação de redes de amizades e contatos profissionais, a melhoria de seu desempenho profissional, o orgulho de serem os primeiros de suas famílias a alcançarem uma formação superior, como elementos importantes na sua percepção de mobilidade social.

Ainda que seja uma instituição privada, o SENAI oferece cursos gratuitos no nível técnico. Os cursos superiores de tecnologia, no entanto, são pagos. A instituição não trabalha com os programas de financiamento e bolsas do governo federal (PROUNI e FIES), mas oferece um sistema próprio de bolsas de estudos, parciais e integrais, com base na análise da situação financeira pessoal e familiar do aluno requerente.

No entanto, a maioria dos estudantes do curso pesquisado trabalha para garantir o pagamento das mensalidades. Nesse sentido, eventualmente o seu desempenho acadêmico pode ser afetado pelo cansaço e pela falta de tempo (embora essas variáveis não tenham sido abordadas neste estudo).

Assim, compreende-se que, ainda que as condições de acesso e permanência na educação superior tenham melhorado muito nesses primeiros 16 anos do século XXI no Brasil, principalmente em função de políticas públicas voltadas para o setor, esse nível educacional ainda não é acessível a toda a população que consegue terminar o Ensino Médio.

Como os níveis salariais, no mercado de trabalho brasileiro, são muito diferentes entre os profissionais com diferentes níveis de escolaridade, conforme mostrado no capítulo anterior, a mobilidade social dessa população é diretamente afetada pela impossibilidade de acessar e concluir a educação superior. 


\section{REFERÊNCIAS}

ALVES, Andressa Schneider. Design do vestuário: protótipo funcional para o encaixe de moldes no tecido. Dissertação (Mestrado em Design). Porto Alegre: UFRGS, 2010.

BARROS, Myriam Moraes Lins de. Trajetórias de jovens adultos: ciclo de vida e mobilidade social. Horizontes Antropológicos. Porto Alegre, ano 16, n. 34, pp. 71-92, jul./dez. 2010. Disponível em:

http://www.scielo.br/pdf/ha/v16n34/04.pdf. Acesso em: 10 out. 2016.

BERSTEIN, Basil. A estruturação do discurso pedagógico: classe, códigos e controle. Petrópolis: Vozes, 1996.

Educação Profissional Técnica de Nível Médio Integrada

ao Ensino Médio. Brasília: Secretaria de Educação Profissional e Tecnológica, Ministério da Educação, 2007.

BOURDIEU, Pierre. A distinção: crítica social do julgamento. Porto Alegre: Zouk, 2007.

BRASIL. Constituição dos Estados Unidos do Brasil (de 10 de novembro de 1937). Disponível em:

http://www.planalto.gov.br/ccivil_03/Constituicao/Constituicao37.htm. Acesso em 9 jan. 2017.

BRESSER-PEREIRA, Luiz Carlos. Empresários e Administradores no Brasil. São Paulo: Brasiliense, 1974.

Mobilidade social: uma avaliação

comparativa. Revista Administração de Empresas. Rio de Janeiro, v. 13, n. 4, pp. 19-35, out./dez. 1973.

CENSO da Educação Superior 2013 - Resumo Técnico. Brasília: INEP/DEED, 2015. Disponível em:

http://download.inep.gov.br/download/superior/censo/2013/resumo_tecnico_cen so_educacao_superior_2013.pdf. Acesso em: 30 nov. 2016.

CENTENÁRIO da Rede Federal de Educação Profissional e Tecnológica. Histórico da Educação Profissional. Brasília: Secretaria de Educação Profissional e Tecnológica, Ministério da Educação, 2009. Disponível em: http://portal.mec.gov.br/setec/arquivos/centenario/historico_educacao_profissio nal.pdf. Acesso em: 10 jul. 2016.

CERVO, Amado L.; BERVIAN, Pedro A. Metodologia Científica. 5.ed., São Paulo: Prentice Hall, 2002.

CHRISTOPHE, Micheline. A legislação sobre a Educação Tecnológica, no quadro da Educação Profissional brasileira. Rio de Janeiro: Instituto de 
Estudos do Trabalho e Sociedade, 2005. Disponível em: http://tupi.fisica.ufmg.br/michel/docs/Artigos_e_textos/Gestao_de_cooperativas/ educacao\%20tecnologica.pdf. Acesso em: 12 dez. 2016.

CUNHA, Luiz Antonio. O ensino industrial-manufatureiro no Brasil. Revista Brasileira de Educação, n. 14, pp. 89-107, mai/jun/jul/ago 2000.

DRUCKER, Peter. Sociedade pós-capitalista. São Paulo: Pioneira, 1999.

DUARTE, Newton. As pedagogias do "aprender a aprender" e algumas ilusões da assim chamada sociedade do conhecimento. Revista Brasileira de Educação, n. 18, pp. 35-40, set/out/nov/dez 2001.

ESCOTT, Clarice Monteiro; MORAES, Márcia Amaral Correa de. História da Educação Profissional no Brasil: as políticas públicas e o novo cenário de formação de professores nos Institutos Federais de Educação, Ciência e Tecnologia. Anais. IX Seminário Nacional de Estudos e Pesquisas "História, Sociedade e Educação no Brasil". Universidade Federal da Paraíba, João Pessoa, 31/7 a 3/8/2012. Disponível em:

http://www.histedbr.fe.unicamp.br/acer_histedbr/seminario/seminario9/PDFs/2.5 1.pdf. Acesso em:

FREIRE, Paulo. Pedagogia da Autonomia: saberes necessários à prática educativa. 29.ed., São Paulo: Paz e Terra, 1996.

FRIGOTTO, Gaudêncio. As relações do trabalho-educação e o Labirinto do Minotauro. In: AZEVEDO, José Clóvis; GENTILI, Pablo; KRUG, Andrá; SIMON, Cátia. Utopia e Democracia na Educação Cidadã. Porto Alegre: UFRGS; Secretaria Municipal de Educação de Porto Alegre, 2000.

GADOTTI, Moacir. História da ideias pedagógicas. 8.ed., São Paulo: Ática, 2002.

GARCIA, Nilson Marcos Dias; LIMA FILHO, Domingos Leite. Politecnia ou educação tecnológica: desafios ao Ensino Médio e à educação profissional. Trabalho encomendado pelo GT-9 - Trabalho e Educação, para apresentação na 27ª. Reunião Anual da ANPEd (Caxambu, 2004).

KANAMARU, Antonio Takao. Função didática-pedagógica do design de moda baseado em fibra têxtil vegetal diante da fome global. Anais. 6 o Colóquio de Moda, São Paulo, 2010. Disponível em:

http://www.coloquiomoda.com.br/anais/anais/6-Coloquio-deModa_2010/71812_Funcao_didatica-pedagogica_do_design_de_moda.pdf. Acesso em: 9 jan. 2017.

Autonomia, cooperativismo e autogestão em Freinet: fundamentos de uma pedagogia solidária internacional. Educação e Pesquisa, São Paulo, v. 40, n. 3, p. 767-781, jul./set. 2014.

KUENZER, Acácia Z. (org.). Ensino Médio: construindo uma proposta para os que vivem do trabalho. São Paulo: Cortez, 2007. 
LAKATOS, Eva Maria. Sociologia geral. 4.ed., São Paulo: Atlas, 1981.

LEMOS, Ana Heloisa da Costa; DUBEUX, Veranise Jacubowski Correia;

PINTO, Mario Couto Soares. Educação, empregabilidade e mobilidade social: convergências e divergências. Cadernos Ebape, v. 7, oㅡ 2, artigo 8, Rio de Janeiro, jun./2009.

LOBO, Renato Nogueirol. Proposta de procedimento para verificar a viabilidade de utilização do pelo do Canis lupus familaris da raça poodle na fabricação de fios têxteis. 2014. 130f. Dissertação (Mestrado). Escola de Artes, Ciências e Humanidades, Universidade de São Paulo, São Paulo, 2014.

MACEDO, Arthur Roquete de. Apresentação. In: MOTOYAMA, Shozo (Org.).

Educação técnica e tecnológica em questão. São Paulo: UNESP; CEETEPS, 1995.

MACEDO, Lino de. Competências e habilidades: elementos para uma reflexão pedagógica. In: BRASIL. Ministério da Educação. Instituto Nacional de Estudos e Pesquisas Educacionais Anísio Teixeira. Exame Nacional do Ensino Médio (Enem): fundamentação teórico-metodológica. Brasília, 2005a, p. 13-28.

Disponível em: <http:/www.nota10serie.com.br/wp-content/uploads/ FundamentoTeoricoMetodologico1.pdf>. Acesso em: 20 jul. 2016.

Propostas para pensar sobre situações-problema. In: BRASIL. Ministério da Educação. Instituto Nacional de Estudos e Pesquisas Educacionais Anísio Teixeira. Exame Nacional do Ensino Médio (Enem): fundamentação teórico-metodológica. Brasília, 2005b. p. 37-39. Disponível em: $<$ http://www.nota10serie.com.br/wpcontent/uploads/FundamentoTeoricoMetodologico1.pdf>. Acesso em: 20 jul. 2016.

MACHADO, Weverthon Barbosa. Mobilidade social e cultura política no Brasil. 8o Encontro ABCP, Gramado - RS, 1-4 agosto 2012. Disponível em: http://www.cienciapolitica.org.br/wpcontent/uploads/2014/04/27_7_2012_0_39_42.pdf. Acesso em: 10 jul. 2016.

MARX, K. O capital. Livro I. (Os economistas). São Paulo: Nova Cultural, 1985. MAXIMIANO, Antonio Cesar Amaru. Teoria Geral da Administração: da Revolução Urbana à Revolução Digital. 7.ed., São Paulo: Atlas, 2012.

MOTOYAMA, Shozo (Org.). Educação técnica e tecnológica em questão. São Paulo: UNESP; CEETEPS, 1995.

NERI, M. A nova classe média: o lado brilhante da base da pirâmide. São Paulo: Saraiva, 2011.

NORONHA, Nayara Silva de; BARBOSA, Deborah Mara Siade. Renda, consumo e centralidade do trabalho na "nova classe média" brasileira. RAMRev. Adm. Mackenzie, 17(1), 40-54, São Paulo, jan./fev./2016. 
PERRENOUD, Philippe. Construir as competências desde a escola. Porto Alegre: Artmed, 1999.

Artmed, 2000.

10 novas competências para ensinar. Porto Alegre:

PIMENTEL, Fernando. Setor Têxtil e de Confecção: momento atual e agenda de trabalho. Circuito ABIT/Texbrasil. Belém / São Paulo: ABIT, 25/2/2016.

Disponível em: http://www.abit.org.br/cont/perfil-do-setor. Acesso em: 11 nov. 2016.

POCHMANN, Márcio. Trabalho e formação. Educação e Realidade, v. 37, n. 2, Porto Alegre, mai./ago. 2012.

POSTER, M. Teoria crítica da família. Rio de Janeiro: Zahar, 1979.

RIBEIRO, Carlos Antônio Costa. Mobilidade e Estrutura de Classes no Brasil Contemporâneo. Sociologias. Porto Alegre, ano 16, n. 37, set./dez. 2014, p. 178-217.

SAVIANI, Dermeval. Pedagogia histórico-crítica. 11.ed., Campinas: Autores Associados, 2012.

SCHULTZ, Theodore. O valor econômico da educação. Rio de Janeiro: Zahar, 1967.

SCHWARTZMAN, Simon; BOMENY, Helena Maria Bousquet; COSTA, Vanda Maria Ribeiro. Tempos de Capanema. Rio de Janeiro: Paz e Terra; São Paulo: EDUSP, 1984.

SEMESP. Mapa do Ensino Superior 2015. SEMESP, 2015. Disponível em: http://www.semesp.org.br/site/pesquisas/mapa-do-ensino-superior/mapa-doensino-superior-2015/. Acesso em: 2 jul.2016.

SILVA, Edna Lúcia da; CUNHA, Miriam Vieira da. A formação profissional no século XXI: desafios e dilemas. Ciência da Informação, Brasília, v. 31, n. 3, pp. 77-82, set./dez. 2002.

SILVA, Gabriele Bonotto; FELICETTI, Vera Lucia. Habilidades e competências na prática docente: perspectivas a partir de situações-problema. Educação por Escrito, Porto Alegre, v. 5, n. 1, p. 17-29, jan.-jun. 2014.

SOUZA, Jessé. Os batalhadores brasileiros: nova classe média ou nova classe trabalhadora? 2.ed., Belo Horizonte: UFMG, 2012.

SOROKIN, Pitirim A. Social Mobility. 2v. New York: Harper \& Brothers, 1927.

STAVENHAGEN, Rodolfo. Classes sociais e estratificação social. In: FORACCHI, Marialice Mencarini; MARTINS, José de Souza. Sociologia e Sociedade. Rio de Janeiro: LTC, 1999.

TOFFLER. Alvin. Powershift: as mudanças do poder. Rio de Janeiro: Record, 1998. 
TREVISAN, Leonardo. Educação e Trabalho: as receitas inglesas na era da instabilidade. 2.ed., São Paulo: SENAC, 2010. 
ANEXOS

\section{Anexo 1 - Questionário da Etapa 1}

Untitled form

PERGUNTAS

RESPOSTAS

50

Seção 1 de 6

\section{Questionário de Pesquisa Público Alvo}

Caros Eternos Alunos!!!

Esta pesquisa é Fundamental para a Conclusão da minha Dissertação do Mestrado então, a ajuda do discente é de extrema

relevância e importância. Agradeço a todos que puderem disponibilizar do seu tempo para as respostas e já deixo o meu forte abraço

e o desejo de Sucesso a todos em suas caminhadas.

Do sempre Amigo!!!

Edmundo Pedro

\section{Pergunta}

Opção 1

Nome Completo do ex discente: *

Texto de resposta longa

Qual a localização do domicílio do ex discente?*

Zona Leste de São Paulo

Zona Oeste de São Paulo

Zona Norte de São Paulon

Zona Sul de São Paulo

Grande ABC

Interior do Estado de São Paulo

Outro...

$+\quad$ Tr 
Untitled form

PERGUNTAS

Alugado

Outro...

Qual a idade do ex discente?*
de 20 a 22 anos
de 22 a 24 anos
de 24 a 26 anos
de 26 a 30 anos
de 30 a 34 anos
de 35 a 39 anos
Acima de $\mathbf{4 0}$ anos

Conclusão do ensino médio do ex discente foi em: *

Escola pública

Escola particular

Após a seção 1 Continuar para a próxima seção

Seção 2 de 6

\section{Informações sobre seus pais ou responsáveis}

Descrição (opcional)

$\oplus \quad$ TT

凹

$\square$ 
Untitled form

PERGUNTAS

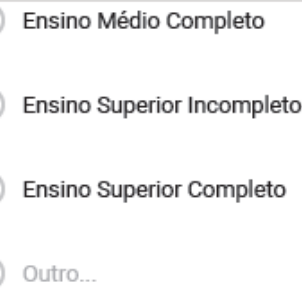

Qual o nível de Escolaridade da mãe ou responsável do ex discente?*

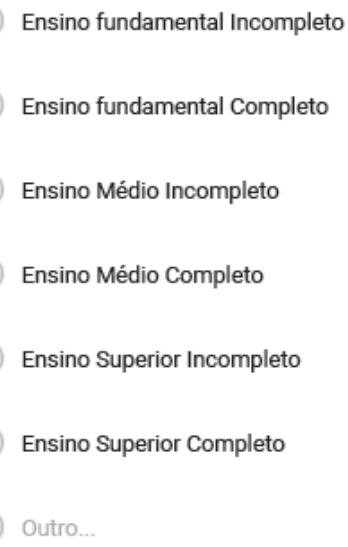

Qual a Profissão do pai ou responsável do ex discente?*

Texto de resposta longa

Qual a Profissão da mãe ou responsável do ex discente? *

O ex discente mora com os pais ou responsáveis? ${ }^{*}$

(1) Sim

$\odot \quad$ TT 
Untitled form

PERGUNTAS

Outro...

Os pais ou responsáveis do ex discente moram em: *

Casa

Apartamento

Outros

Qual a localização da moradia dos pais ou responsáveis do ex discente?*
Zona Leste de São Paulo
Zona Oeste de São Paulo
Zona Norte de São Paulo
Zona Sul de São Paulo
Grande ABC
Interior do Estado de São Paulo
Outro...

Qual a renda salarial dos pais ou responsáveis do ex discente? *
de 1 a 2 salários mínimos
de 2 a 5 salários mínimos
de 5 a 7 salários mínimos
de 7 a 10 salários mínimos

$+\quad$ Tт 


\section{Informações sobre outros membros da familia}

Descrição (opcional)

O ex discente possui irmãos? *

Sim
Não

Os irmão compõem na sua renda familiar?

Sim

Não

Qual o estado civil do ex discente?*

Solteiro(a)

Casado(a)

Viúvo(a)

Divorciado(a)

Relacionamento estável

União estável

O Cônjuge compõem na sua renda familiar? *

$+\quad$ TT

T

แ 
Sim

Não

Se sim. Quantos filhos possui?*
1
2
3
Mais que 3 filhos
Não possui filhos

Seu(s) filho(s) concluírá(ão) o ensino básico (fundamental e médio):
Em escola pública
Em escola particular

Após a seção 3 Continuar para a próxima seção

Seção 4 de 6

\section{Situação profissional antes de iniciar o curso}

Descrição (opcional)

Antes de iniciar o curso de Superior de Tecnologia em Produção de Vestuário qual era * a func:ão do (ex) discente? Pode Colocar mais de um oncão

$\odot$

TT

$\square$

$\nabla$ 
Untitled form

PERGUNTAS

Outro...

Caso estivesse trabalhando antes de iniciar o curso, qual o cargo que atuava? *

Texto de resposta longa

Qual a faixa salarial do ex discente antes do início do curso ?*

de 1 a 2 salários mínimos

de 2 a 5 salários mínimos

de 5 a 7 salários mínimos

de 7 a 10 salários mínimos

de 10 a15 salários mínimos

de 15 a 20 salários mínimos

mais de 20 salários mínimos

Não provinha de renda

Antes da realização do curso, o ex discente contribuía para a renda familiar? *

Sim. Contribuía com a renda familiar antes de iniciar o curso.

Não. A minha renda nunca foi necessária para suporte à renda familiar

Sim. Pois a renda principal provinha do meu trabalho.

Não. Pois não provinha de renda antes de iniciar o curso

Outro...

$\odot \quad$ TT

口 


\section{de Tecnologia em Produção de Vestuário}

Descrição (opcional)

Após concluir o curso Superior de Tecnologia em Produção de Vestuário o ex discente está atuando na Cadeia Têxtil e Moda?

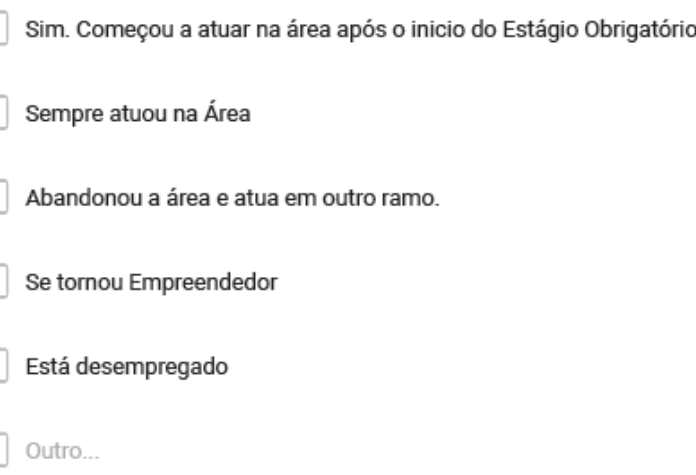

Qual a faixa salarial do ex discente após a conclusão do curso? *
de 1 a 2 salários mínimos
de 2 a 5 salários mínimos
de 5 a 7 salários mínimos
de 7 a 10 salários mínimos
( de 10 a15 salários mínimos

$\odot \quad$ TT 


\section{Benefícios proporcionados pela realização do curso}

Descrição (opcional)

Quais foram as conquistas técnicas / culturais obtidas após a realização do curso? Pode assinalar mais de uma alternativa

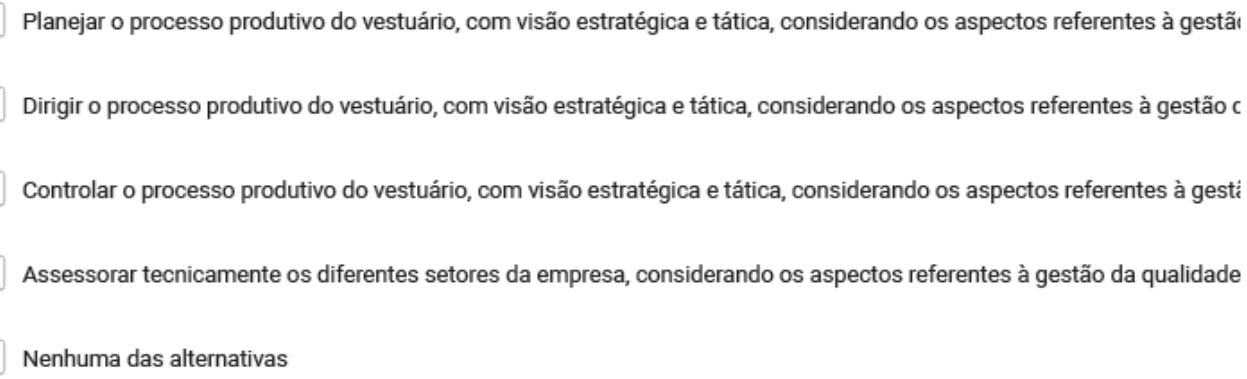

Quais foram as conquistas profissionais obtidas após a realização do curso? Pode assinalar mais de uma alternativa

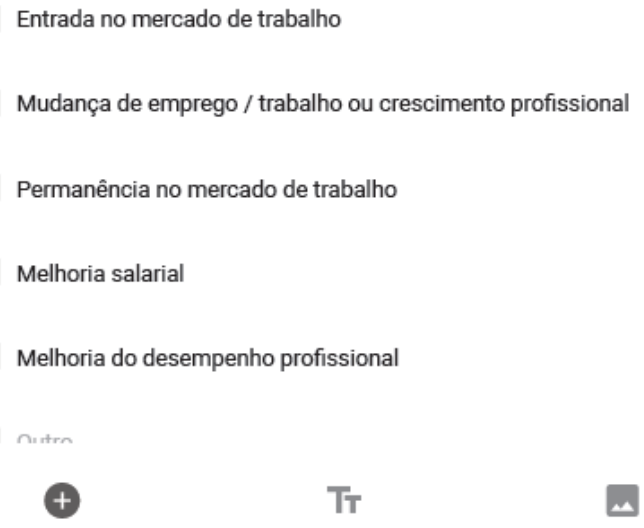


Untitled form

PERGUNTAS

RESPOSTAS

50

Empresa própria

$\square$ Outro...

$\oplus$

TT

4

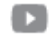




\section{Pesquisa Egressos do Curso Superior de Tecnologia em Produção de Vestuário Senai}

Esta pesquisa faz parte da minha dissertação de Mestrado. Ao respondê-la, você vai me ajudar a realizá-la com sucesso. Muito obrigado pela sua colaboração! Grande abraço! Ed Pedro

Nome completo (não será divulgado; apenas para controle do pesquisador); data de nascimento.

Sua resposta

1. Em que ano você iniciou o Curso Superior de Produção de Vestuário no Senai?

Data

$\mathrm{dd} / \mathrm{mm} /$ aaaa

2. Em que ano você concluiu o curso?

Data

$\mathrm{dd} / \mathrm{mm} /$ aaaa

3. Você concluiu o Ensino Médio em:

Escola pública

Escola particular 

4.Você cursou Ensino Técnico?
Sim
Não

5.Se "sim", qual curso você fez? E em qual instituição?

6.Qual é o nível de escolaridade de seu pai?

Ensino Fundamental incompleto

Ensino Fundamental completo

Ensino Médio incompleto

Ensino Médio completo

Ensino Superior incompleto

Ensino Superior completo

7.Qual é o nível de escolaridade de sua mãe?

Ensino Fundamental incompleto

Ensino Fundamental completo

Ensino Médio incompleto

Ensino Médio completo

Ensino Superior incompleto

Ensino Superior completo

8.Atualmente, você é:

Funcionário público

Empregado de empresa privada

Profissional autônomo 
Empresário

9.Você mora em:

Casa/apartamento próprio

Casa/apartamento alugado

Outra situação de moradia

\section{Você mora com:}

cônjuge

cônjuge e filho(s)

pais ou avós

pai/avô

mãe/avó

amigos (divide moradia)

sozinho

11.Antes do curso, sua situação de moradia era:

Casa/apartamento próprio

Casa/apartamento alugado

Outra situação de moradia

12.Sua situação profissional antes do curso era:

Funcionário público

Empregado de empresa privada

Profissional autônomo 
Empresário

Estudante

$\bigcirc$ Desempregado

13.Antes do curso, sua faixa de renda pessoal (não familiar) era:

1 a 2 salários mínimos

2 a 5 salários mínimos

○ a 7 salários mínimos

7 a 10 salários mínimos

Acima de 10 salários mínimos

14.Após a conclusão do curso, você atua na cadeia Têxtil e Moda?

○ sim

Não

15.Sua faixa de renda pessoal (não familiar) atual é:

1 a 2 salários mínimos

2 a 5 salários mínimos

5 a 7 salários mínimos

7 a 10 salários mínimos

Acima de 10 salários mínimos

16.0 que você pode apontar como benefícios trazidos pela realização do curso? (Assinale quantas alternativas quiser)

$\square$ Inserção no mercado de trabalho

Mudança para um emprego melhor 
Promoção na empresa em que já atuava

Permanência no mercado de trabalho

$\square$ Melhoria salarial

$\square$ Melhoria do seu desempenho profissional

$\square$ Abertura de empresa própria

$\square$ Aquisição de imóvel(is)

Aquisição de automóvel(is)

Outro:

Nunca envie senhas pelo Formulários Google. 


\title{
Anexo 3 - Perfil do Tecnólogo em Produção de Vestuário
}

\author{
Área Profissional: Indústria \\ Segmento Tecnológico: Vestuário \\ Qualificação Profissional: Tecnólogo em Produção de Vestuário \\ Nível de Educação Profissional: Tecnológico \\ Nível de Qualificação: 4
}

\section{COMPETÊNCIAS PROFISSIONAIS}

Competência Geral
Planejar, dirigir e controlar o processo produtivo do vestuário, com visão estratégica e tática, e
assessorar tecnicamente os diferentes setores da empresa, considerando os aspectos referentes à
gestão da qualidade, aos princípios éticos e à responsabilidade sócio - ambiental, com foco nos
resultados organizacionais.

\section{Relação das Unidades de Competência}

Unidade de Competência 1: Planejar o processo produtivo do vestuário, com visão estratégica e tática, considerando os aspectos referentes à gestão da qualidade, aos princípios éticos e à responsabilidade socioambiental, com foco nos resultados organizacionais.

Unidade de Competência 2: Dirigir o processo produtivo do vestuário, com visão estratégica e tática, considerando os aspectos referentes à gestão da qualidade, aos princípios éticos e à responsabilidade socioambiental, com foco nos resultados organizacionais.

Unidade de Competência 3: Controlar o processo produtivo do vestuário, com visão estratégica e tática, considerando os aspectos referentes à gestão da qualidade, aos princípios éticos e à responsabilidade socioambiental, com foco nos resultados organizacionais.

Unidade de Competência 4: Assessorar tecnicamente os diferentes setores da empresa, considerando os aspectos referentes à gestão da qualidade, aos princípios éticos e à responsabilidade socioambiental, com foco nos resultados organizacionais. 


\section{Unidade de Competência 1}

Planejar o processo produtivo do vestuário, com visão estratégica e tática, considerando os aspectos referentes à gestão da qualidade, aos princípios éticos e à responsabilidade socioambiental, com foco nos resultados organizacionais.

\begin{tabular}{|c|c|c|}
\hline \multirow{2}{*}{\begin{tabular}{|c|} 
Elementos de Competência \\
$\begin{array}{l}\text { 1.1 Avaliar os recursos necessários ao processo } \\
\text { produtivo, considerando decisões do } \\
\text { planejamento estratégico. }\end{array}$
\end{tabular}} & \multicolumn{2}{|r|}{ Padrões de Desempenho } \\
\hline & 1.1 .1 & $\begin{array}{lr}\text { Identificando as quantidades de } \\
\text { matérias-primas necessárias } \\
\text { diferentes processos de produção }\end{array}$ \\
\hline & 1.1 .2 & $\begin{array}{l}\text { Identificando equipamentos e máquinas } \\
\text { necessários aos diferentes processos de } \\
\text { produção }\end{array}$ \\
\hline & 1.1 .3 & $\begin{array}{l}\text { Identificando a mão-de-obra necessária } \\
\text { aos diferentes processos de produção }\end{array}$ \\
\hline \multirow{6}{*}{$\begin{array}{l}\text { 1.2 Desenvolver alternativas de melhoria ao } \\
\text { processo produtivo. }\end{array}$} & 1.2 .1 & Analisando históricos de produção \\
\hline & 1.2 .2 & $\begin{array}{l}\text { Propondo a implementação de novas } \\
\text { tecnologias }\end{array}$ \\
\hline & 1.2 .3 & $\begin{array}{l}\text { Propondo a aplicação de normas } \\
\text { técnicas }\end{array}$ \\
\hline & 1.2 .4 & $\begin{array}{l}\text { Propondo medidas de preservação da } \\
\text { saúde e segurança }\end{array}$ \\
\hline & 1.2 .5 & $\begin{array}{l}\text { Propondo medidas de redução de } \\
\text { impactos ambientais }\end{array}$ \\
\hline & 1.2 .6 & $\begin{array}{l}\text { Propondo medidas de preservação da } \\
\text { segurança patrimonial }\end{array}$ \\
\hline \multirow{4}{*}{$\begin{array}{l}\text { 1.3 Determinar o custo operacional do processo } \\
\text { produtivo }\end{array}$} & 1.3 .1 & Calculando o custo dos materiais \\
\hline & 1.3 .2 & Calculando o tempo de produção \\
\hline & 1.3 .3 & Calculando os custos da mão-de-obra \\
\hline & 1.3 .4 & Calculando os custos indiretos \\
\hline \multirow[t]{6}{*}{ 1.4 Prever a continuidade do processo produtivo } & 1.4 .1 & Provendo logística interna \\
\hline & 1.4 .2 & Provendo logística externa \\
\hline & 1.4 .3 & Gerenciando contratos \\
\hline & 1.4 .4 & Utilizando sistemas de gestão \\
\hline & 1.4 .5 & Utilizando logística reversa \\
\hline & 1.4 .6 & Elaborando o plano de manutenção \\
\hline
\end{tabular}




\begin{tabular}{|c|c|c|}
\hline \multirow[t]{7}{*}{$\begin{array}{l}\text { 1.5 Elaborar plano do processo produtivo da } \\
\text { empresa }\end{array}$} & 1.5 .1 & $\begin{array}{l}\text { Definindo as etapas a serem cumpridas } \\
\text { durante o processo }\end{array}$ \\
\hline & 1.5 .2 & Definindo as estratégias de produção \\
\hline & 1.5 .3 & $\begin{array}{l}\text { Integrando as atividades de produção às } \\
\text { demais funções da empresa }\end{array}$ \\
\hline & 1.5 .4 & Alocando os recursos necessários \\
\hline & 1.5 .5 & Definindo leiaute \\
\hline & 1.5 .6 & $\begin{array}{l}\text { Definindo estratégias de controle de } \\
\text { qualidade }\end{array}$ \\
\hline & 1.5 .7 & $\begin{array}{l}\text { Estabelecendo cronograma } \\
\text { atividades do processo produtivo }\end{array}$ \\
\hline
\end{tabular}




\section{Unidade de Competência 2}

Dirigir o processo produtivo do vestuário, com visão estratégica e tática, considerando os aspectos referentes à gestão da qualidade, aos princípios éticos e à responsabilidade socioambiental, com foco nos resultados organizacionais.

\begin{tabular}{|c|c|c|}
\hline Elementos de Competência & & Padrões de Desempenho \\
\hline 2.1 Formar equipes de alto-resultado & $\begin{array}{l}2.1 .1 \\
2.1 .2 \\
2.1 .3 \\
2.1 .4\end{array}$ & $\begin{array}{l}\text { Avaliando a capacidade dos profissionais } \\
\text { Capacitando profissionais } \\
\text { Exercendo liderança } \\
\text { Utilizando métodos adequados de } \\
\text { formação de equipes }\end{array}$ \\
\hline 2.2 Negociar com indivíduos e grupos & $\begin{array}{l}2.2 .1 \\
2.2 .2 \\
2.2 .3 \\
2.2 .4 \\
2.2 .5 \\
\end{array}$ & $\begin{array}{l}\text { Demonstrando capacidade de } \\
\text { comunicação } \\
\text { Administrando conflitos } \\
\text { Interagindo com outros setores da } \\
\text { empresa } \\
\text { Demonstrando comportamento ético } \\
\text { Demonstrando capacidade de persuasão }\end{array}$ \\
\hline $\begin{array}{l}\text { 2.3 Coordenar as atividades do processo } \\
\text { produtivo }\end{array}$ & $\begin{array}{l}2.3 .1 \\
2.3 .2 \\
2.3 .3 \\
\\
2.3 .4 \\
2.3 .5 \\
2.3 .6\end{array}$ & $\begin{array}{l}\text { Distribuindo funções } \\
\text { Definindo prioridades } \\
\text { Estabelecendo os critérios de } \\
\text { desempenho esperados } \\
\text { Estimulando as pessoas } \\
\text { Diminuindo discrepâncias de } \\
\text { desempenho } \\
\text { Exercendo a boa governança corporativa }\end{array}$ \\
\hline
\end{tabular}




\section{Unidade de Competência 3}

Controlar o processo produtivo do vestuário, com visão estratégica e tática, considerando os aspectos referentes à gestão da qualidade, aos princípios éticos e à responsabilidade socioambiental, com foco nos resultados organizacionais.

\begin{tabular}{|c|c|c|}
\hline Elementos de Competência & \multicolumn{2}{|r|}{ Padrões de Desempenho } \\
\hline \multirow[t]{6}{*}{$\begin{array}{l}\text { 3.1 Estabelecer os métodos de controle do } \\
\text { processo produtivo }\end{array}$} & 3.1 .1 & $\begin{array}{l}\text { Definindo os métodos quantitativos de } \\
\text { controle do processo produtivo }\end{array}$ \\
\hline & 3.1 .2 & $\begin{array}{l}\text { Definindo métodos qualitativos de } \\
\text { controle do processo produtivo }\end{array}$ \\
\hline & 3.1 .3 & $\begin{array}{l}\text { Propondo medidas de prevenção da } \\
\text { saúde e segurança dos profissionais }\end{array}$ \\
\hline & 3.1 .4 & $\begin{array}{l}\text { Propondo medidas de manutenção da } \\
\text { segurança patrimonial }\end{array}$ \\
\hline & 3.1 .5 & $\begin{array}{l}\text { Propondo medidas de monitoramento } \\
\text { dos impactos socioambientais }\end{array}$ \\
\hline & 3.1 .6 & $\begin{array}{l}\text { Orientando a utilização de normas } \\
\text { técnicas }\end{array}$ \\
\hline \multirow[t]{4}{*}{$\begin{array}{l}\text { 3.2 Avaliar os resultados da utilização dos } \\
\text { métodos de controle }\end{array}$} & 3.2 .1 & $\begin{array}{l}\text { Analisando os indicadores } \\
\text { desempenho }\end{array}$ \\
\hline & 3.2 .2 & $\begin{array}{l}\text { Monitorando os resultados } \\
\text { desempenho }\end{array}$ \\
\hline & 3.2 .3 & $\begin{array}{l}\text { Analisando a consistência dos resultados } \\
\text { obtidos }\end{array}$ \\
\hline & 3.2 .4 & $\begin{array}{l}\text { Interpretando os resultados obtidos no } \\
\text { processo produtivo }\end{array}$ \\
\hline \multirow[t]{6}{*}{$\begin{array}{l}\text { 3.3 Ajustar o processo produtivo às metas } \\
\text { estabelecidas, se necessário }\end{array}$} & 3.3 .1 & $\begin{array}{l}\text { Redefinindo as etapas a serem } \\
\text { cumpridas durante o processo }\end{array}$ \\
\hline & 3.3.2 & $\begin{array}{l}\text { Readequando as estratégias de } \\
\text { produção }\end{array}$ \\
\hline & 3.3 .3 & $\begin{array}{l}\text { Revendo a integração das atividades de } \\
\text { produção às demais funções da empresa }\end{array}$ \\
\hline & 3.3.4 & Alocando os recursos necessários \\
\hline & 3.3 .5 & $\begin{array}{l}\text { Redefinindo as estratégias de controle da } \\
\text { qualidade }\end{array}$ \\
\hline & 3.3.6 & Redefinindo leiaute \\
\hline
\end{tabular}




\section{Unidade de Competência 4}

Assessorar tecnicamente os diferentes setores da empresa, considerando os aspectos referentes à gestão da qualidade, aos princípios éticos e à responsabilidade sócio- ambiental, com foco nos resultados organizacionais.

\begin{tabular}{|c|c|c|}
\hline Elementos de Competência & & Padrões de Desempenho \\
\hline \multirow[t]{5}{*}{ 4.1 Fornecer subsídios técnicos e tecnológicos } & 4.1 .1 & Propondo alterações técnicas ao produto \\
\hline & 4.1 .2 & $\begin{array}{l}\text { Propondo alterações técnicas ao } \\
\text { processo }\end{array}$ \\
\hline & 4.1 .3 & Participando de grupos de opinião \\
\hline & 4.1 .4 & $\begin{array}{l}\text { Informando sobre novos materiais e } \\
\text { técnicas de produção }\end{array}$ \\
\hline & 4.1 .5 & $\begin{array}{l}\text { Indicando as características dos } \\
\text { profissionais necessários }\end{array}$ \\
\hline \multirow[t]{4}{*}{ 4.2 Avaliar sistemas disponíveis no mercado } & 4.2 .1 & Indicando sua aplicabilidade \\
\hline & 4.2 .2 & Indicando a viabilidade econômica \\
\hline & 4.2 .3 & Pesquisando novos meios de produção \\
\hline & 4.2 .4 & $\begin{array}{l}\text { Fornecendo subsídios técnicos e } \\
\text { tecnológicos }\end{array}$ \\
\hline
\end{tabular}




\section{Anexo 4 - Conhecimentos Referentes ao Perfil Profissional}

\begin{tabular}{|c|c|}
\hline Unidade de Competência & Conhecimentos \\
\hline $\begin{array}{l}\quad \text { Unidade de Competência } 1 \\
\text { Planejar o processo produtivo do } \\
\text { vestuário, com visão estratégica e } \\
\text { tática, considerando os aspectos } \\
\text { referentes à gestão da qualidade, aos } \\
\text { princípios éticos e à responsabilidade } \\
\text { socioambiental, com foco nos } \\
\text { resultados organizacionais. }\end{array}$ & $\begin{array}{l}\text { Legislação contratual } \\
\text { Estudo de tempos e métodos } \\
\text { Administração da produção } \\
\text { Planejamento estratégico e estratégico situacional } \\
\text { Administração de custos } \\
\text { Normas regulamentadoras } \\
\text { Logística } \\
\text { Gestão ambiental }\end{array}$ \\
\hline $\begin{array}{l}\quad \text { Unidade de Competência n } 2 \\
\text { Dirigir o processo produtivo do } \\
\text { vestuário, com visão estratégica e } \\
\text { tática, considerando os aspectos } \\
\text { referentes à gestão da qualidade, aos } \\
\text { princípios éticos e à responsabilidade } \\
\text { socioambiental, com foco nos } \\
\text { resultados organizacionais. }\end{array}$ & $\begin{array}{l}\text { Gestão de pessoas } \\
\text { Comportamento organizacional } \\
\text { Governança corporativa } \\
\text { Negociação }\end{array}$ \\
\hline $\begin{array}{l}\quad \text { Unidade de Competência } 3 \\
\text { Controlar o processo produtivo do } \\
\text { vestuário, com visão estratégica e } \\
\text { tática, considerando os aspectos } \\
\text { referentes à gestão da qualidade, aos } \\
\text { princípios éticos e à responsabilidade } \\
\text { socioambiental, com foco nos } \\
\text { resultados organizacionais. }\end{array}$ & $\begin{array}{l}\text { Métodos quantitativos } \\
\text { Métodos qualitativos } \\
\text { Gestão da qualidade } \\
\text { Saúde e segurança } \\
\text { Segurança patrimonial }\end{array}$ \\
\hline \begin{tabular}{l}
\multicolumn{1}{c}{ Unidade de Competência 4} \\
Assessorar tecnicamente os diferentes \\
setores da empresa, considerando os \\
aspectos referentes à gestão da \\
qualidade, aos princípios éticos e à \\
responsabilidade socioambiental, com \\
foco nos resultados organizacionais.
\end{tabular} & $\begin{array}{l}\text { Custos } \\
\text { Tecnologia da informação } \\
\text { Tecnologia têxtil } \\
\text { Gestão de projetos } \\
\text { Estudo da viabilidade técnica e econômica } \\
\text { Engenharia de processo } \\
\text { Negociação } \\
\text { Tecnologia em dispositivos } \\
\text { Marketing e finanças } \\
\text { Tecnologia do vestuário }\end{array}$ \\
\hline
\end{tabular}

